VILNIAUS GEDIMINO TECHNIKOS UNIVERSITETAS

Rokas GIRDŽIUS

\title{
BETONO TEMPIAMOJO SUSTANDÉJIMO MODELIS ATITINKANTIS EURONORMŲ NUOSTATAS
}

DAKTARO DISERTACIJA

TECHNOLOGIJOS MOKSLAI, STATYBOS INŽINERIJA (02T) 
Disertacija rengta 2004-2011 metais Vilniaus Gedimino technikos universitete. Disertacija ginama eksternu.

\section{Mokslinis konsultantas}

prof. habil. dr. Gintaris KAKLAUSKAS (Vilniaus Gedimino technikos universitetas, statybos inžinerija - 02T).

Vilniaus Gedimino technikos universiteto Statybos inžinerijos mokslo krypties disertacijos gynimo taryba:

\section{Pirmininkas}

prof. habil. dr. Juozas ATKOČIŪNAS (Vilniaus Gedimino technikos universitetas, statybos inžinerija - 02T).

\section{Nariai:}

prof. habil. dr. Jonas BAREIŠIS (Kauno technologijos universitetas Panevéžio institute, mechanikos inžinerija - 09T),

prof. dr. Zdenek KALA (Brno technologijos universitetas, statybos inžinerija-02T),

prof. dr. Romualdas KLIUKAS (Vilniaus Gedimino technikos universitetas, statybos inžinerija - 02T),

prof. dr. Juozas VALIVONIS (Vilniaus Gedimino technikos universitetas, statybos inžinerija - 02T).

Disertacija bus ginama viešame Statybos inžinerijos mokslo krypties disertacijos gynimo tarybos posedyje 2012 m. sausio 5 d. 14 val. Vilniaus Gedimino technikos universiteto senato posèdžių salëje.

Adresas: Sauletekio al. 11, LT-10223 Vilnius, Lietuva.

Tel.: (8 5) 274 4956; faksas (8 5) 270 0112; el. paštas doktor@vgtu.lt

Pranešimai apie numatomą ginti disertaciją išsiusti $2011 \mathrm{~m}$. gruodžio $2 \mathrm{~d}$.

Disertacija galima peržiūrèti interneto svetainèje http://dspace.vgtu.lt ir Vilniaus Gedimino technikos universiteto bibliotekoje (Sauletekio al. 14, LT-10223 Vilnius, Lietuva).

VGTU leidyklos „Technika“ 1941-M mokslo literatūros knyga.

ISBN 978-609-457-025-4

(C) VGTU leidykla TECHNIKA, 2011

(C) Rokas Girdžius, 2011

rokaspro@yahoo.com 
VILNIUS GEDIMINAS TECHNICAL UNIVERSITY

Rokas GIRDŽIUS

TENSION-STIFFENING MODEL FOR REINFORCED CONCRETE MEMBERS ACCORDING EUROCODE

DOCTORAL DISSERTATION

TECHNOLOGICAL SCIENCES,

CIVIL ENGINEERING (02T)

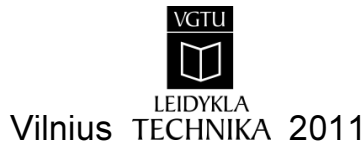


Doctoral dissertation was prepared at Vilnius Gediminas Technical University in 2004-2011.

The dissertation is defended as an external work.

\section{Scientific Consultant}

Prof Dr Habil Gintaris KAKLAUSKAS (Vilnius Gediminas Technical University, Civil Engineering - 02T).

The Dissertation Defence Council of Scientific Field of Civil Engineering of Vilnius Gediminas Technical University:

\section{Chairman}

Prof Dr Habil Juozas ATKOČIŪNAS (Vilnius Gediminas Technical University, Civil Engineering - 02T).

\section{Members:}

Prof Dr Habil Jonas BAREIŠIS (Kaunas University of Technology, Mechanical Engineering - 09T),

Prof Dr Zdenek KALA (Brno University of Technology, Civil Engineering $-02 \mathrm{~T})$,

Prof Dr Romualdas KLIUKAS (Vilnius Gediminas Technical University, Civil Engineering - 02T),

Prof Dr Juozas VALIVONIS (Vilnius Gediminas Technical University, Civil Engineering - 02T).

The dissertation will be defended at the public meeting of the Disertation Defence Council of Civil Engineering in the Senate Hall of Vilnius Gediminas Technical University at 2 p. m. on 5 January 2012.

Adress: Saulètekio al. 11, LT-10223 Vilnius, Lithuania.

Tel.: +370 5274 4956; fax +370 52700112 ; e-mail: doktor@vgtu.lt

A notification on the intended defending of the dissertation was send on 2 December 2011.

A copy of the doctoral dissertation is available for review at the Internet website http://dspace.vgtu.lt and at the Library of Vilnius Gediminas Technical University (Saulètekio al. 14, LT-10223 Vilnius, Lithuania). 


\section{Reziumè}

Disertacijoje nagrinejjama trumpalaike apkrova veikiamų tempiamujų ir lenkiamujų gelžbetoninių elementų itempiu ir deformacijų skaičiavimo metodai. Kaip yra žinoma, supleišejusiame gelžbetoniniame elemente plyšio vietoje betono tempimo itempiai yra lygus nuliui, o visą išorinès apkrovos sukeltą irąžą atlaiko armatūra. Kadangi plyšyje ir gretimuose pjūviuose armatūra praslysta betono atžvilgiu, kontakto zonoje atsiranda tangentiniai itempiai. Šie itempiai perduodami betonui, todèl jis atlaiko tempimo įtempius. Armatūros ir betono sąveika ruožuose tarp plyšiu standina gelžbetonini elementą. Supleišejusio betono gebejjimas atlaikyti tempimo itempius vadinama tempiamuoju sustandejjimu (angl. tension stiffening). Pagrindinis disertacijos tikslas yra remiantis Euronormų deformacijų skaičiavimo metodika, pasiūlyti trumpalaike apkrova veikiamų tempiamuju ir lenkiamuju gelžbetoninių elementų tempiamojo sustandejimo modelius, tinkamus taikyti skaitiniuose metoduose.

Disertaciją sudaro ìvadas, keturi skyriai, darbo rezultatai ir išvados, literatūros sąrašas ir autoriaus publikacijos tema sąrašas.

Ivadiniame skyriuje nagrinejjamas problemos aktualumas, formuluojamas darbo tikslas bei uždaviniai, aprašomas mokslinis darbo naujumas, pristatomi autoriaus pranešimai ir publikacijos, disertacijos struktūra.

Pirmasis skyrius skirtas literatūros analizei. Apžvelgti medžiagų modeliai (armatūra, gniuždomas betonas, tempiamas betonas), pleišèjimo modeliai, armatūros ir betono sukibimas), pateikti skaitiniai bei analiziniai ir empiriniai gelžbetoninių elementų deformacijų skaičiavimo metodai. Skyriaus pabaigoje formuluojamos išvados ir konkretizuojami disertacijos uždaviniai.

Antrajame ir trečiajame skyriuose, taikant Euronormų deformacijų skaičiavimo nuostatas, pateikiami tempiamojo sustandejjimo modeliu išvedimai, atitinkamai, tempiamiesiems ir lenkiamiesiems gelžbetoniniams elementams. Taip pat trečiajame skyriuje pasiūlytas Euronormas atitinkantis supaprastintas lenkiamujų gelžbetoninių elementų momentų-kreivių skaičiavimo metodas. Skyrių pabaigoje formuluojamos išvados.

Ketvirtajame disertacijos skyriuje tiriamas gautujų tempiamojo sustandejjimo modelių tikslumas, vertinant gelžbetoninių elementų deformacijas. Pateikiami lenkiamujjų gelžbetoninių elementų skaitinio modeliavimo pavyzdžiai taikant darbe pasiūlytuosius tempiamojo sustandèjimo modelius. Skyriaus pabaigoje formuluojamos išvados.

Disertacijos tema išspausdinti 9 moksliniai straipsniai: 4 recenzuojamuose mokslo žurnaluose (2 iš jų - ISI WEB of Science referuojamuose duomenų bazèse), 5 straipsniai mokslinių konferencijų medžiagoje (1 iš jų - tarptautinèje mokslinès konferencijos medžiagoje). 


\section{Abstract}

Study analyses the issue of tensile and flexural RC members strains and deformations caused by a short term load. The concrete ability to carry a certain amount of tensile stresses between cracks (due to bond with reinforcement) is called tension-stiffening. The phenomenon, called tension-stiffening, has significant influence on the results of short-term deformational analysis. The main objective of this study is to propose tension-stiffening models for tension and bending RC members affected by a short term load and suitable for using in numerical methods with reference of Eurocode.

Dissertation consists of introduction, four chapters, results, conclusions and author publications on the topic of the dissertation.

The introduction presents reasons for investigation, main objective and tasks of the work, scientific novelty and originality, basic statements to be defended, list of publications by the author.

The first chapter presents literature review on material models (reinforcement, compressed concrete, tensile concrete), cracking models. Furthermore design code and numerical methods for determining deflormations of reinforced concrete members are reviewed. Conclusions and tasks are formulated at the end of the chapter.

The second and third chapters presents derivations of tension stiffening models according to Eurocode. Also, third chapter reports simplified RC elements in bending moment-curvature calculation method. The conclusions are formulated at the end of the chapter.

The fourth chapter presents analysis of tension stiffening models precision, considering RC elements deformations. Numerical modeling examples of RC elements in bending practicing author suggested tension stiffening models. Conclusions are formulated at the end of the Chapter.

9 scientific articles were published on the topic of the dissertation: 4 - in reviewed scientific journals (2 from them included in ISI WEB of Science international databases), 5 articles in conferences materials ( 1 from them in international conference material). 


\section{Žymèjimai}

\section{Simboliai}

$$
\begin{array}{ll}
A_{c} & - \text { betono skerspjūvio plotas; } \\
A_{s} & - \text { armatūros skerspjūvio plotas; } \\
A_{s}^{\prime} & - \text { gniuždomos armatūros skerspjūvio plotas; } \\
C & - \text { betono klasė; } \\
E_{c} & - \text { betono tamprumo modulis; } \\
E_{c \alpha} & - \text { efektyvusis betono tamprumo modulis; } \\
E_{s} & - \text { armatūros tamprumo modulis; } \\
E_{c s e c} & - \text { kirstinis betono tamprumo modulis; } \\
E I & - \text { lenkiamojo elemento standumas; } \\
b & - \text { skerspjūvio plotis; } \\
b_{f} & - \text { dvitèjinio (tèjinio) skerspjūvio lentynos plotis; } \\
d & - \text { efektyvusis skerspjūvio aukštis; } \\
f_{c} & - \text { betoninio stipris gniuždant; }
\end{array}
$$




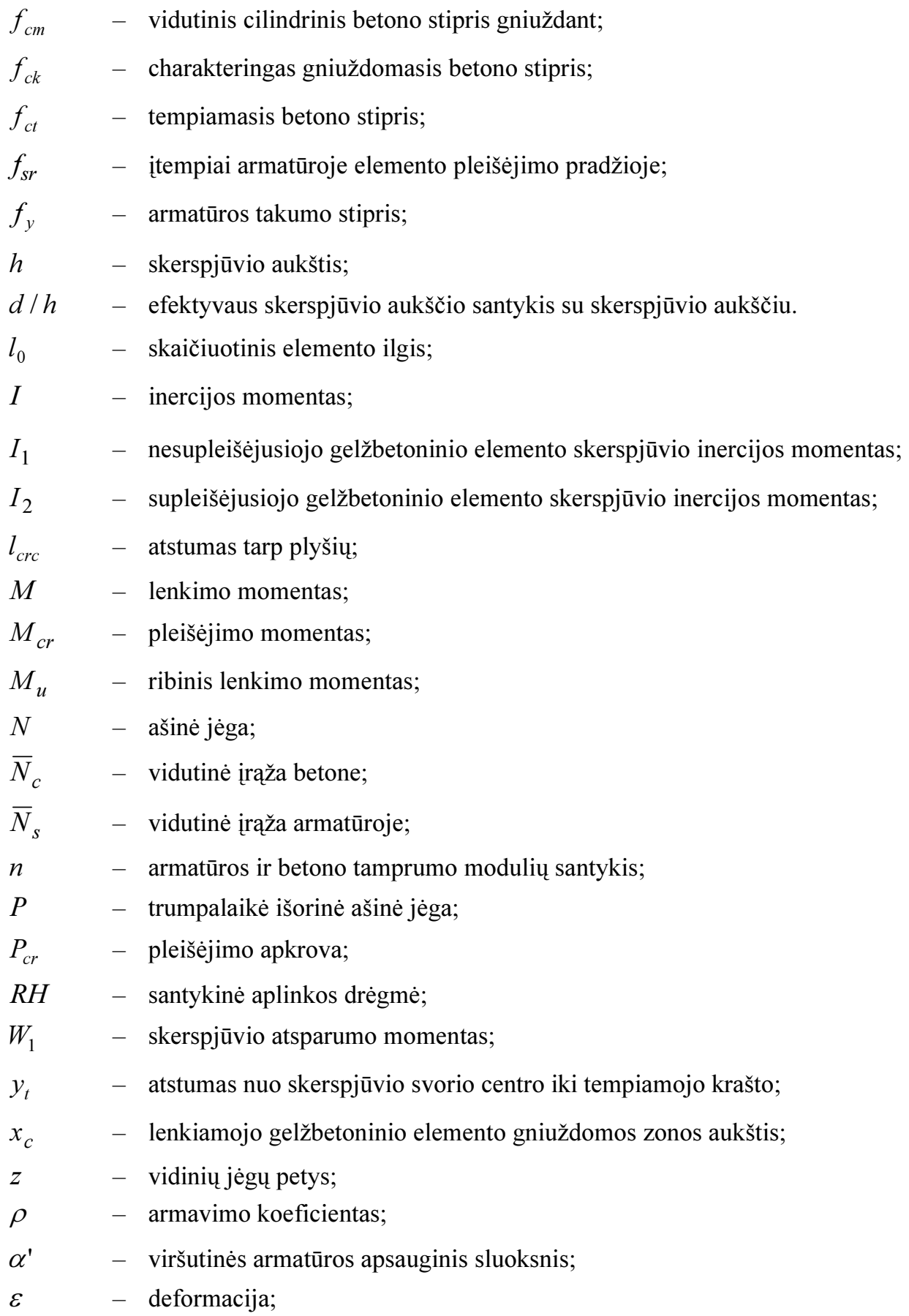




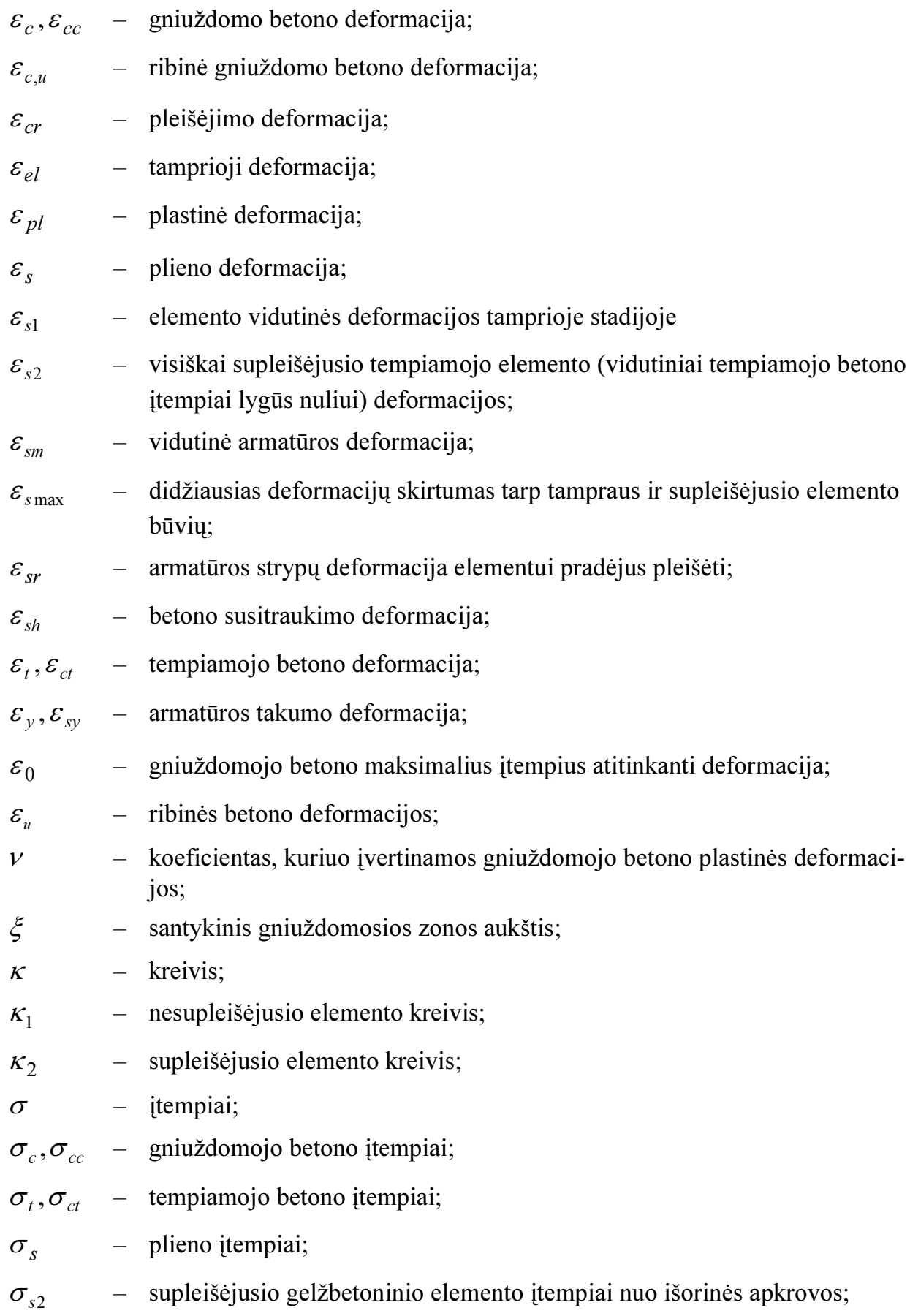
itempiai lygūs nuliui) deformacijos;

$\varepsilon_{s m} \quad-$ vidutinè armatūros deformacija;

$\varepsilon_{s \max }-$ didžiausias deformacijų skirtumas tarp tampraus ir supleišejjusio elemento būvių;

$\varepsilon_{s r} \quad-$ armatūros strypų deformacija elementui pradejjus pleišèti;

$\varepsilon_{s h} \quad-$ betono susitraukimo deformacija;

$\varepsilon_{t}, \varepsilon_{c t}-$ tempiamojo betono deformacija;

$\varepsilon_{y}, \varepsilon_{s y}-$ armatūros takumo deformacija;

$\varepsilon_{0} \quad-$ gniuždomojo betono maksimalius įtempius atitinkanti deformacija;

$\varepsilon_{u} \quad-$ ribinès betono deformacijos;

$v \quad-$ koeficientas, kuriuo ịvertinamos gniuždomojo betono plastinės deformacijos;

$\xi \quad-\quad$ santykinis gniuždomosios zonos aukštis;

$\kappa \quad-$ kreivis;

$\kappa_{1} \quad-$ nesupleišejusio elemento kreivis;

$\kappa_{2}-$ supleišèjusio elemento kreivis;

$\sigma \quad-$ itempiai;

$\sigma_{c}, \sigma_{c c}-$ gniuždomojo betono įtempiai;

$\sigma_{t}, \sigma_{c t}-$ tempiamojo betono itempiai;

$\sigma_{s} \quad-$ plieno ittempiai;

$\sigma_{s 2} \quad-$ supleišèjusio gelžbetoninio elemento ittempiai nuo išorinès apkrovos; 
$\sigma_{s r} \quad-$ supleišejusio tempiamojo gelžbetoninio elemento įtempiai neviršijantys betono stiprio tempiant;

$\varphi_{f} \quad-\quad$ koeficientas, ịvertinantis gniuždomosios armatūros bei gniuždomosios zonos formos itaka;

$\tau \quad-$ tangentiniai įtempiai. 


\section{Turinys}

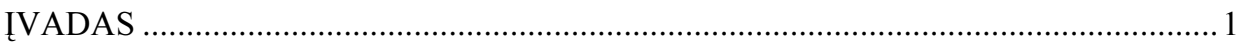

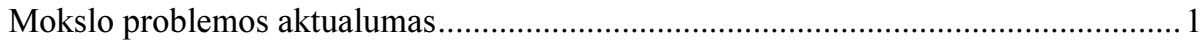

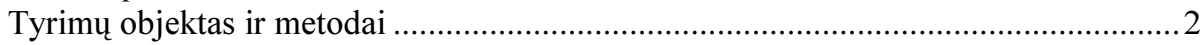

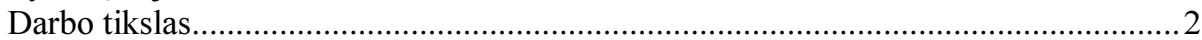

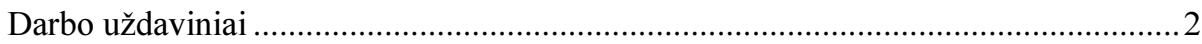

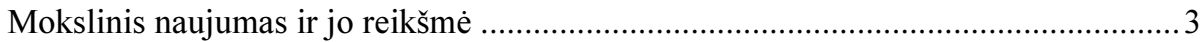

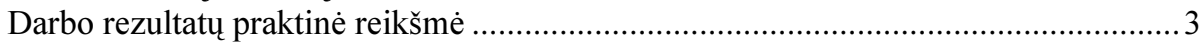

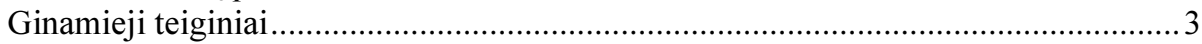

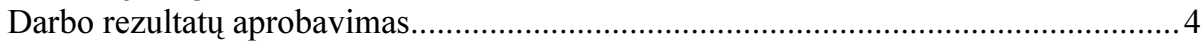

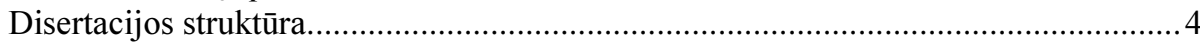

1. GELŽBETONINIŲ ELEMENTU ITEMPIŲ IR DEFORMACIJŲ SKAIČIAVIMO

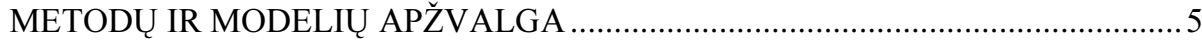

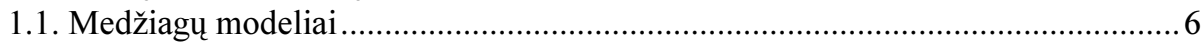

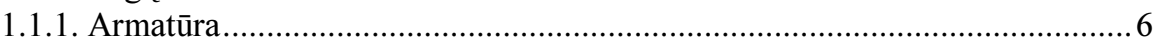

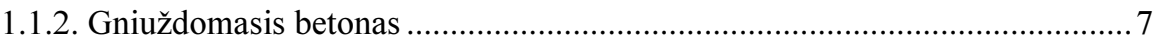

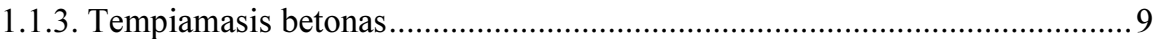

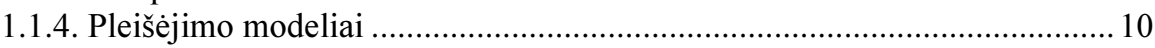

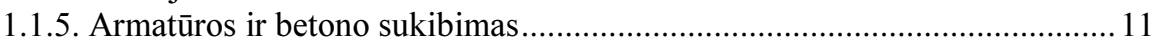

1.1.6. Tempiamojo sustandejjimo modeliai ............................................................. 12 


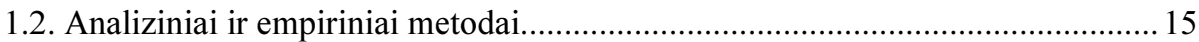

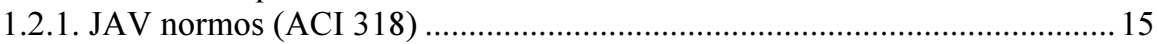

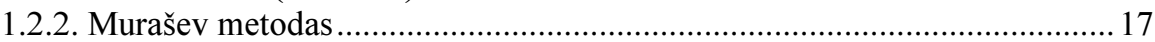

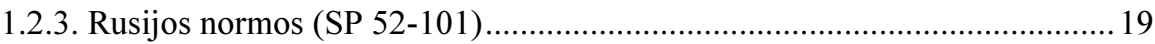

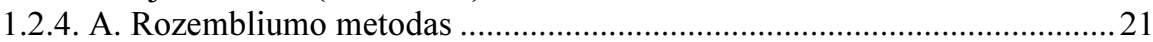

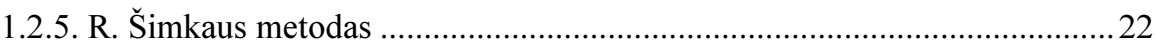

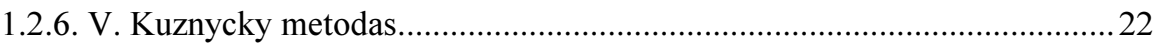

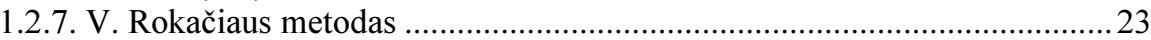

1.3. Pirmojo skyriaus rezultatai, išvados ir disertacijos uždavinių formulavimas......24

2. TEMPIAMŲJŲ GELŽBETONINIŲ ELEMENTŲ TEMPIAMOJO SUSTANDĖJI-

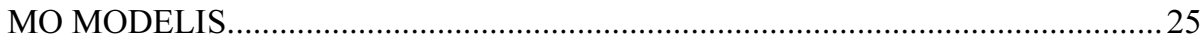

2.1. Deformacijų skaičiavimo metodas pagal Euronormas ......................................26

2.2. Itempių ir deformacijų diagramų nustatymo metodika .......................................2. 29

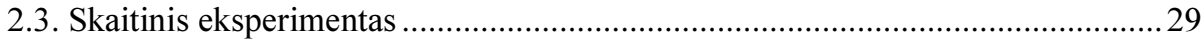

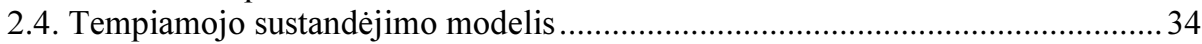

2.5. Tempiamojo sustandèjimo diagrama pagal CEB-FIP metodą...............................37

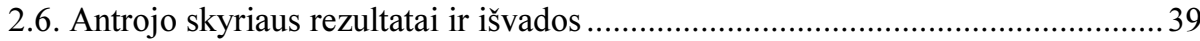

3. LENKIAMŲJŲ GELŽBETONINIŲ ELEMENTŲ TEMPIAMOJO SUSTANDĖJI-

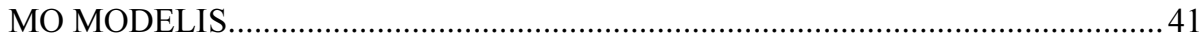

3.1. Momentų-kreivių skaičiavimas pagal EC2 metodą............................................42

3.2. Trumpas metodo aprašymas tempiamojo sustandëjimo kreivei išvesti iš lenkiamujų gelžbetoninių elementų momentų-kreivių diagramų .....................................4 43

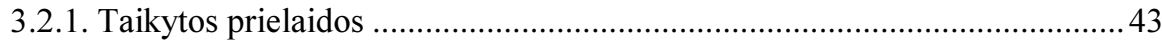

3.2.2. Pagrindinès geometrijos ir pusiausvyros lygtys........................................... 44

3.2.3. Supleišèjusio betono įtempių-deformacijų diagramų nustatymo metodas, taikant lenkiamujų gelžbetoninių elementų eksperimentinius duomenis ............45

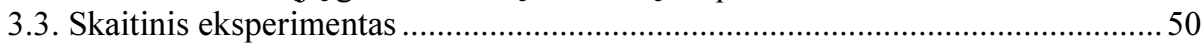

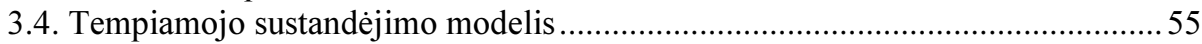

3.5. Nesudètingas lenkiamujų gelžbetoninių elementų kreivių skaičiavimo

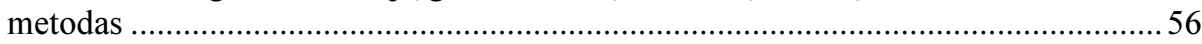

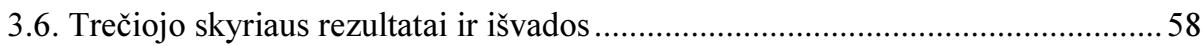

4. SKAITINIAI IR PALYGINAMIEJI SKAIČIAVIMAI TAIKANT PASIŪLYTUO-

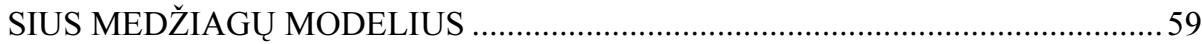

4.1. Tempiamujų gelžbetoninių elementų eksperimentinių ir teorinių deformacijų pa-

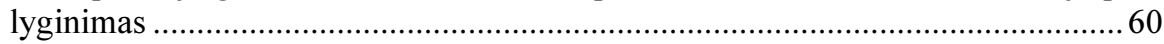

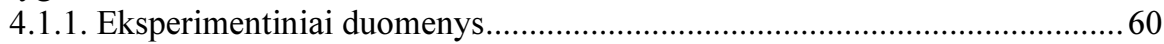

4.1.2. Tempiamojo betono ịtempių ir deformacijų diagramų gavimas iš eksperi-

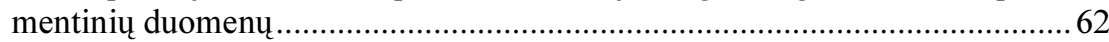

4.1.3. Gautosios ir kitų autorių pasiūlytų tempiamojo betono įtempių ir deformaci-

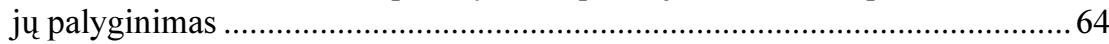

4.2. Lenkiamujų gelžbetoninių elementų eksperimentinių teorinių deformacijų palyginimas 


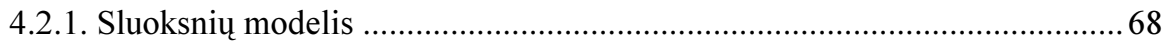

4.2.2. Eksperimentinių lenkiamujų gelžbetoninių elementų analizè ......................70

4.2.3. Gautujų ir kitų autorių pasiūlytų tempiamojo betono itempių ir

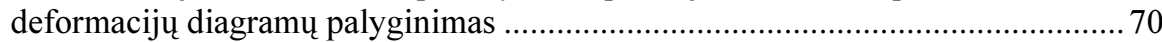

4.2.4. Tempiamojo sustandèjimo diagramos, gautos iš tempiamujuc gelžbetoninių elementų, taikymas lenkiamuose elementuose.................................74

4.3. Lenkiamuju gelžbetoninių elementų deformacijų skaičiavimas, taikant

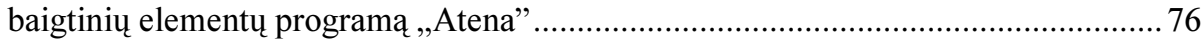

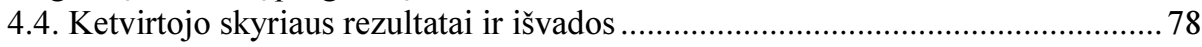

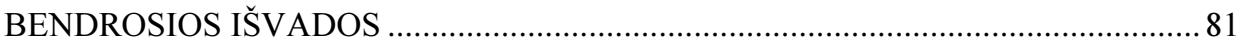

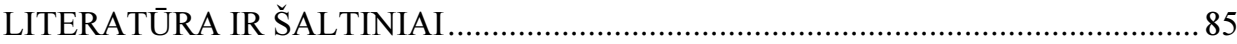

AUTORIAUS PUBLIKACIJŲ DISERTACIJOS TEMA SĄRAŠAS ............................97

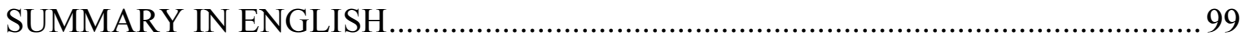

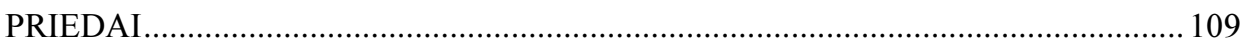

A priedas. Eksperimentinių tempiamujų gelžbetoninių elementų apkrovosdeformacijų ir tempiamojo sustandejjimo diagramos

B priedas. Skaitinių ir palyginamujų skaičiavimų taikant pasiūlytuosius medžiagų modelius gauti rezultatai..................................................... 123

C priedas. Bendraautorių sutikimai teikti publikacijų medžiagą disertacijoje ......... 127

D priedas. Autoriaus mokslinių publikacijų disertacijos tema kopijos 135 



\section{Contents}

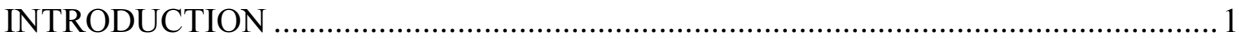

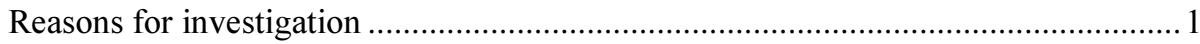

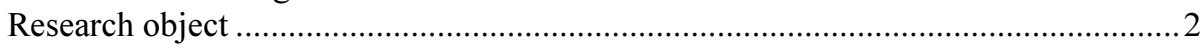

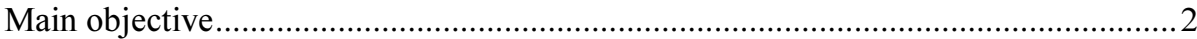

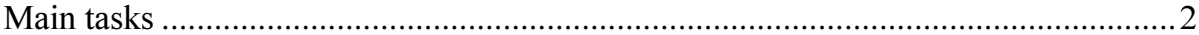

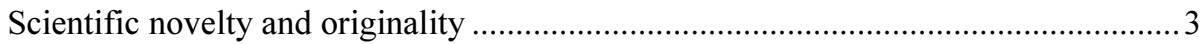

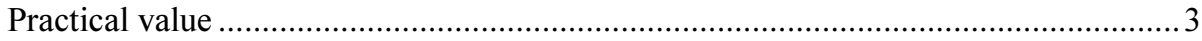

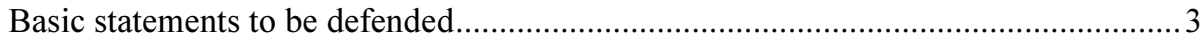

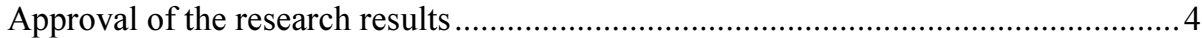

The scope of the scientific work............................................................................ 4

1. OVERVIEW OF STRESS-STRAIN CALCULATION METHODS AND MODELS FOR REINFORCED CONCRETE MEMBERS ...............................5

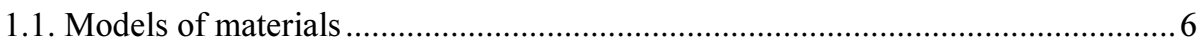

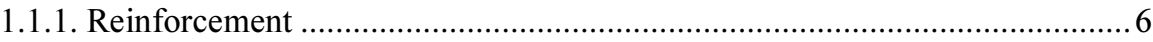

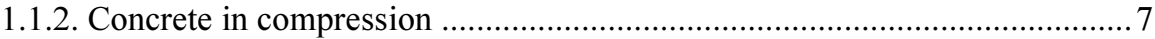

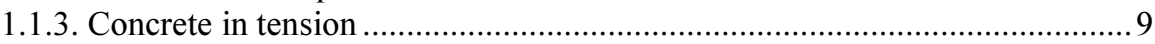

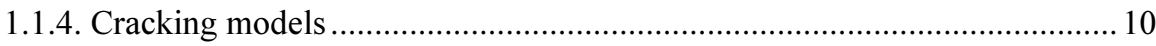

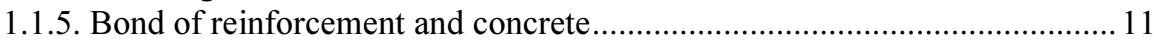

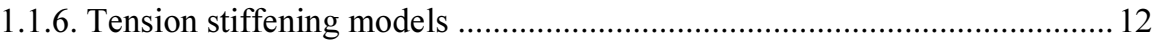

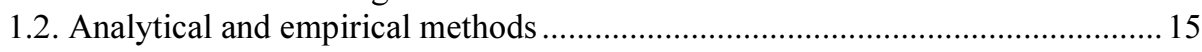

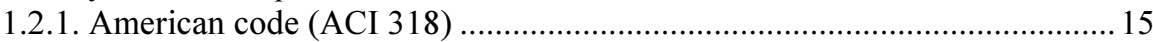




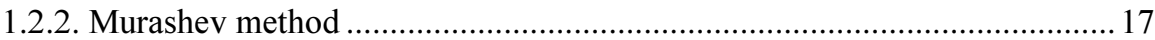

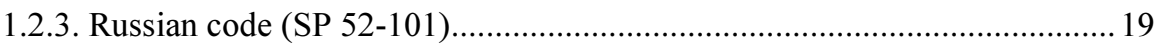

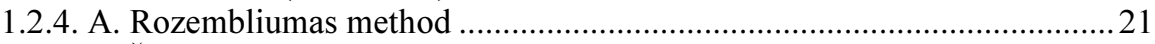

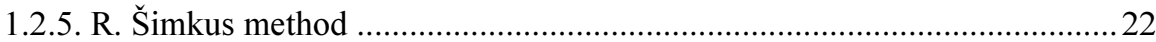

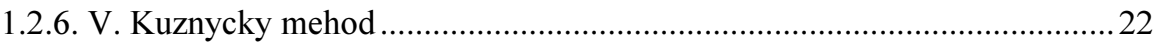

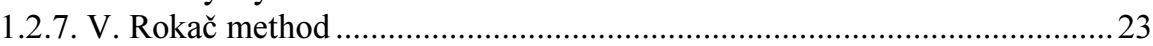

1.3. Conclusions of Chapter 1 and formulating tasks for the dissertation ...................24

2. TENSION-STIFFENING MODEL FOR REINFORCED CONC-

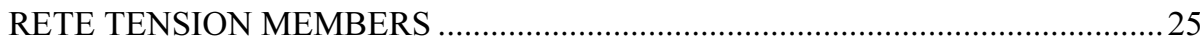

2.1. Deformation calculation method according to Eurocode …………………........26

2.2. Method of derivation of stress and strain diagrams ............................................29

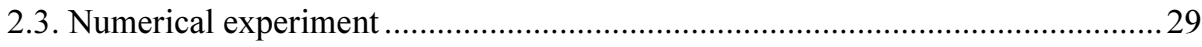

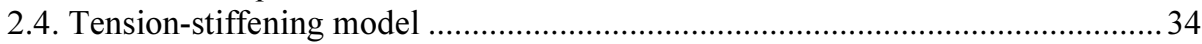

2.5. Tension-stiffening diagram according to CEB-FIP method ..................................37

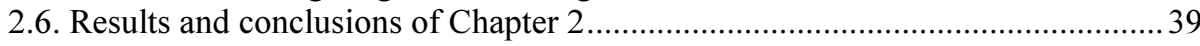

3. TENSION-STIFFENING MODEL FOR REINFORCED CONC-

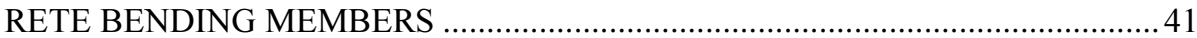

3.1. Moment - curvature calculation according to EC2 method ................................42

3.2. Short description of a method of derivation of tensionstiffening relationships from RC elements' bending moment -

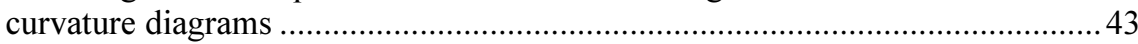

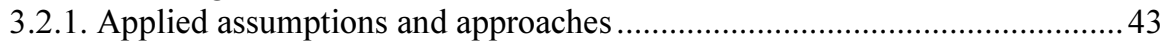

3.2.2. Basic geometrical and equilibrium equations ............................................... 44

3.2.3. Method of derivation of stress - strain diagrams of crac-

ked concrete from test data of flexural RC members ........................................45

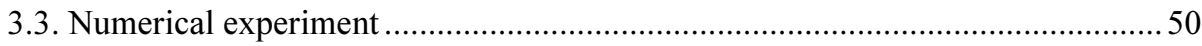

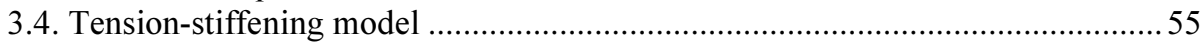

3.5. Simplified curvature calculation method for bending RC ele-

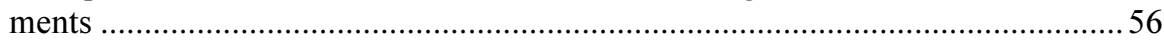

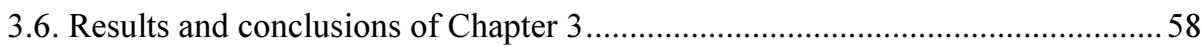

4. NUMERICAL AND COMPARATIVE CALCULATIONS USING

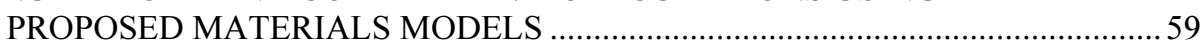

4.1. Comparison of experimental and theorical deformations for RC

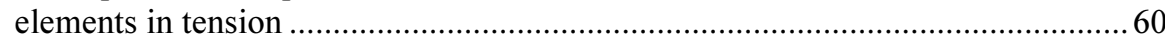

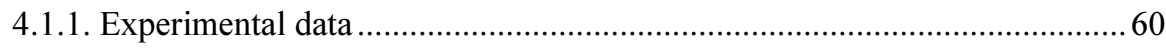

4.1.2. Derivation of sress - strain diagrams of concrete in ten-

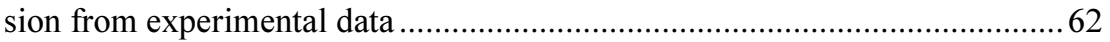

4.1.3. Comparison of defined stress -strain diagrams of concrete

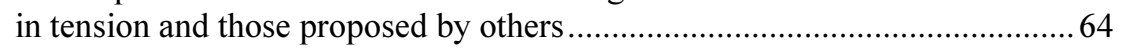

4.2. Comparison of experimental and theoretical deformations RC

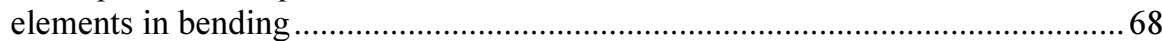

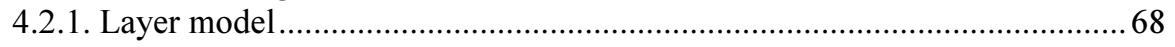


4.2.2. Analysis of experimental RC elements in bending .................................. 70

4.2.3.Comparison of defined stress - strain diagrams of concrete in tension and those proposed by others ............................................... 70

4.2.4. Application of tension-stiffening diagram derived from $\mathrm{RC}$ elements in tension........................................................................ 74

4.3. Calculation of deformation of RC elements in tension using

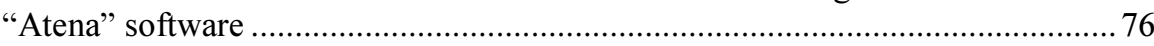

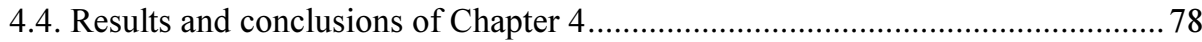

GENERAL CONCLUSIONS ......................................................................... 81

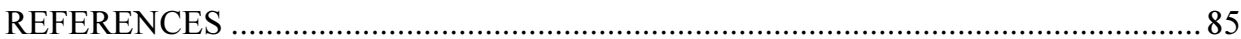

LIST OF PUBLICATIONS BY THE AUTHOR ON THE TOPIC OF

THE DISSERTATION ................................................................................ 97

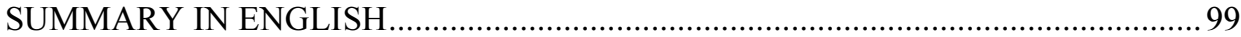

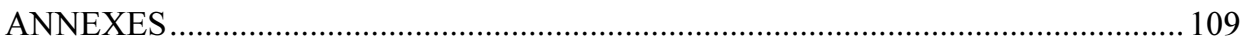

Annex A. Load-deformation and tension stiffening diagrams of tension RC elements .......................................................................... 111

Annex B. The results of numerical and comparative calculations using proposed material models ......................................................... 123

Annex C. The coauthors agreements to present publications for the dissertation defence .................................................................... 127

Annex D. Copies of scientific publications by the autor on the topic of the dissertation 



\section{Ivadas}

\section{Mokslo problemos aktualumas}

Gelžbetonis yra viena plačiausiai statyboje naudojamų medžiagų. Pastaraisiais metais pradejjus naudoti didelio stiprio betoną ir armatūrą, atsirado galimybe projektuoti didesnio tarpatramio ir mažesnio skerspjūvio ploto (liaunesnes) konstrukcijas. Tokių konstrukcijų pagrindiniu projektavimo kriterijumi tampa ne stiprumo, o tinkamumo sąlyga (deformacijos, illinkiai ir plyšio plotis).

Euronormų metodika skirta projektuoti statybines konstrukcijas esant nesudètingam ịtempių būviui. Deja, šis metodas negali būti taikomas sudètingiems konstrukcijų formos ir apkrovimo atvejams. Tokių elementų deformacijų ivvertinimui taikomi skaitiniai metodai, kuriuose ivvertinami netiesiniai medžiagu modeliai. Deformacijų skaičiavime didelę i̇taką turi supleišejusio tempiamojo betono itempių ir deformacijų (tempiamojo sustandejimo) modelis. Deja, Euronormose toks modelis nereglamentuotas, o duodama tik gniuždomojo betono ịtempių ir deformacijų diagrama. Todèl skaitiniais metodais (pavyzdžiui baigtinių elementų) negalima atlikti sudetingų konstrukcijų analizès pagal Euronormų nuostatas.

Praktiškai visi tempiamojo sustandèjimo modeliai gauti apdorojus tempiamujų arba grynaja šlytimi paveiktu gelžbetoninių elementų eksperimentų rezultatus. Taikant tokius modelius lenkiamiesiems elementams, gaunamos nemažos 
deformacijų skaičiavimo paklaidos. Darbe pasiūlyti tempiamojo sustandejjimo modeliai, atitinkantys Euronormų deformacijų skaičiavimo nuostatas. Taikant Vilniaus Gedimino technikos universiteto mokslininkų pasiūlytus atvirkštinio skaičiavimo algoritmus, šie modeliai gauti atskirai tempiamiesiems ir lenkiamiesiems gelžbetoniniams elementams.

\section{Tyrimų objektas ir metodai}

Darbe nagrinejjamas gelžbetoninių elementų tempiamojo sustandejjimo reiškinys. Kuriamas tempimo sustandejimo modelis leidžiantis skaitiniais metodais atlikti gelžbetoninių elementų itempių ir deformacijų būvio analizes pagal Euronormų nuostatas. Disertaciniame darbe taikomi gelžbetonio skaitinio modeliavimo (baigtinių elementu̧, sluoksnių skerspjūvio modelis ir atvirkštinio deformavimo uždavinio sprendimo algoritmas) ir statistinès analizès metodai.

\section{Darbo tikslas}

Remiantis Euronormų deformacijų skaičiavimo metodika, pasiūlyti trumpalaike apkrova veikiamų tempiamujjų ir lenkiamujų gelžbetoninių elementų tempiamojo sustandejjimo modelius, tinkamus taikyti skaitiniuose metoduose.

\section{Darbo uždaviniai}

1. Atlikti gelžbetoninių elementų deformacijų skaičiavimo metodų bei fizinių modelių analizę.

2. Taikant Euronormų deformacijų skaičiavimo metodiką bei naudojant skaitini eksperimenta, gauti trumpalaike apkrova veikiamu tempiamuju ir lenkiamujų gelžbetoninių elementų tempiamojo betono vidutinių itempių ir vidutinių deformacijų diagramas.

3. Atlikti parametrų, turinčiu itakos supleišèjusio betono itempių ir deformacijų diagramos formai, analizę.

4. Pasiūlyti tempiamojo sustandèjimo modelius tempiamiesiems ir lenkiamiesiems gelžbetoniniams elementams.

5. Pasiūlytuosius tempimo sustandèjimo modelius pritaikyti skaitiniuose skaičiavimuose.

6. Surinkti literatūroje paskelbtus tempiamujjų ir lenkiamųjų gelžbetoninių elementų eksperimentinius deformacijų duomenis. 
7. Naudojant literatūroje paskelbtus eksperimentinius duomenis, atlikti tempiamujų elementų deformacijų ir lenkiamujų elementų ilinkių skaičiavimo tikslumo statistinę analizę, taikant šio darbo ir kitu autorių pasiūlytus modelius ir metodus.

\section{Mokslinis naujumas ir jo reikšmè}

Šiame darbe pasiūlyti tempiamojo sustandejjimo modeliai, atitinkantys Euronormų deformacijų skaičiavimo nuostatas. Pasiūlytuosius modelius galima taikyti skaitiniuose metoduose. Gauti skirtingi tempiamojo sustandejimo modeliai tempiamiesiems ir lenkiamiesiems gelžbetoniniams elementams. Nustatyta, kad tempiamojo sustandejjimo modeliai priklauso nuo tempiamojo betono stiprio, armavimo koeficiento bei armatūros ir betono tamprumo modulių santykio.

Naudojant literatūroje paskelbtus eksperimentinius duomenis, atlikta tempiamujų elementų deformacijų ir lenkiamujų elementų ilinkių skaičiavimo tikslumo analizè, taikant šio darbo ir kitų autorių pasiūlytus modelius ir metodus.

\section{Darbo rezultatų praktinė reikšmė}

Pasiūlytieji tempiamojo sustandejjimo modeliai gali būti taikomi baigtinių elementų programose, atliekant gelžbetoninių konstrukcijų analizę pagal Euronormų deformacijų skaičiavimo nuostatas.

\section{Ginamieji teiginiai}

1. Atvirkštinio skaičiavimo algoritmai taikomi tempiamojo sustandejjimo modeliams, atitinkantiems projektavimo normų reikalavimus, kurti.

2. Supleišejusio tempiamojo betono itempių ir deformacijų diagramos tempiamiesiems ir lenkiamiesiems elementams yra skirtingos. Tempiamojo sustandejjimo efektas yra didesnis tempiamuose elementuose lyginant su lenkiamaisiais.

3. Pasiūlytieji tempiamojo sustandejjimo modeliai priklauso nuo betono stiprio, armavimo koeficiento bei armatūros ir betono tamprumo modulių santykio. 


\section{Darbo rezultatų aprobavimas}

Disertacijos tema yra paskelbti keturi moksliniai straipsniai recenzuojamuose mokslo žurnaluose, iš kurių du žurnaluose, itrauktuose i ISI Web of Science sąrašą.

Disertacijoje atliktų tyrimų rezultatai buvo paskelbti 5 pranešimuose 4 mokslinèse konferencijose:

- The third international Congress and exhibition (FIB) incorporating the PCI annual convention \& bridge conference, Washington, USA, 2010.

- 10-oji Lietuvos jaunujų mokslininkų konferencija Mokslas - Lietuvos ateitis, Vilnius, Lietuva, 2007.

- 9-oji Lietuvos jaunujų mokslininkų konferencija Mokslas - Lietuvos ateitis, Vilnius, Lietuva, 2006.

- 8-oji Lietuvos jaunujų mokslininkų konferencija Lietuva be mokslo - Lietuva be ateities, Vilnius, Lietuva, 2005.

\section{Disertacijos struktūra}

Disertaciją sudaro įvadas, keturi skyriai ir rezultatų apibendrinimas. Taip pat yra keturi priedai.

Darbo apimtis yra 110 puslapių, neskaitant priedų, tekste panaudotos 143 numeruotos formulès, 54 paveikslai ir 2 lentelès. Rašant disertaciją buvo panaudoti 155 literatūros šaltiniai. 


\section{1}

\section{Gelžbetoninių elementų itempių ir de- formacijų skaičiavimo metodų ir mo- delių apžvalga}

Ankstyvojoje gelžbetonio teorijos vystymosi stadijoje deformacijų vertinimo problemos nebuvo nagrinejjamos. Pirmieji gelžbetoninių elementų standumo vertinimo metodai buvo paremti klasikiniais medžiagų mechanikos principais, todèl taip apskaičiuoti supleišejjusių gelžbetoninių konstrukcijų illinkiai buvo mažesni už tikruosius. Vèliau, remiantis stiprumo teorija, buvo priimta prielaida, kad skerspjūvyje žemiau neutraliosios ašies betonas neatlaiko tempimo itempių. Tačiau pastebèta, kad supleišèjusio tempiamojo betono tarp plyšiu įtakos ịvertinimas skaičiavimuose sąlygoja žymų konstrukcijos sustandejjimą (angl. tension stiffening). Šis reiškinys buvo aiškinamas supleišèjusio betono gebejjimu atlaikyti tempimo itempius tarp plyšių. Tokiai supleišèjusiojo tempiamojo betono elgsenai įvertinti dažniausiai taikoma vidutinių itempių ir vidutinių deformacijų diagrama, kurios kylančioji dalis apibūdina tampriają betono elgseną, o krentančiaja dalimi ịvertinamas tempimo sustandèjimo efektas.

Tempiamajame betone atsiradus pirmiesiems mikroplyšiams, nustoja galioti tiesine betono itempių ir deformacijų salyga. Itempiams didèjant, mikroplyšiai susijungia ị akimis neįžiūrimus plyšius. Plyšiams pasiekus armatūrą, keičiasi jos itempių ir deformacijų būvis. Staigus vidutinių armatūros deformacijų padidèji- 
mas rodo, jog elemente atsirado pirmasis plyšys. Dèl sukibimo su armatūra tempiamas betonas supleišějusiuose ruožuose atlaiko nemažus vidutinius itempius. Toks bendras tempiamo betono ir armatūros darbas gali ženkliai padidinti konstrukcijos standi. Neįvertinus tempiamojo betono itakos, trumpalaike apkrova veikiamų elementų ilinkiai (kreiviai) gali būti apskaičiuoti su didesne nei $100 \%$ paklaida. Gelžbetoninių konstrukcijų analizei trumpalaikio apkrovimo atveju yra pasiūlyta nemažai i̇vairiomis prielaidomis pagristų supleišèjusio tempiamo betono fizinių modelių.

\subsection{Medžiagų modeliai}

Šiame poskyryje apžvelgiamos įvairios gniuždomojo, tempiamojo betono itempių ir deformacijų diagramos, aptariami betono ir armatūros fiziniai modeliai.

\subsubsection{Armatūra}

Armatūros įtempių ir deformacijų diagrama gali būti aprašoma dvilinijine, trilinijine arba kita diagrama, atitinkančia faktinę armatūros $\sigma-\varepsilon$ diagramą (1.1 pav.).

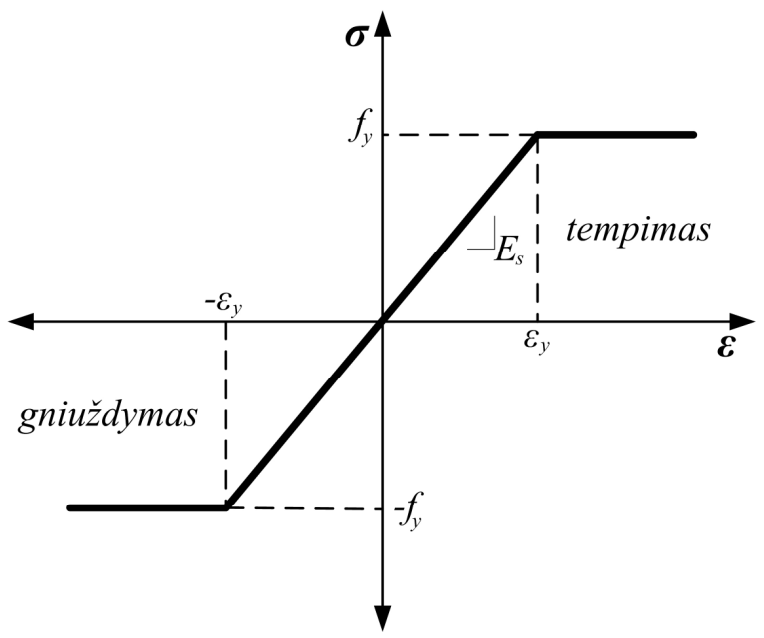

1.1 pav. Armatūros itempių ir deformacijų diagrama

Fig. 1.1. Stress-strain diagram of reinforcement 


\subsubsection{Gniuždomasis betonas}

Betonas yra heterogeninè medžiaga su skirtingomis mechaninèmis savybèmis gniuždant bei tempiant. 1.2 paveiksle pavaizduota gniuždomojo betono itempių ir deformacijų diagrama.

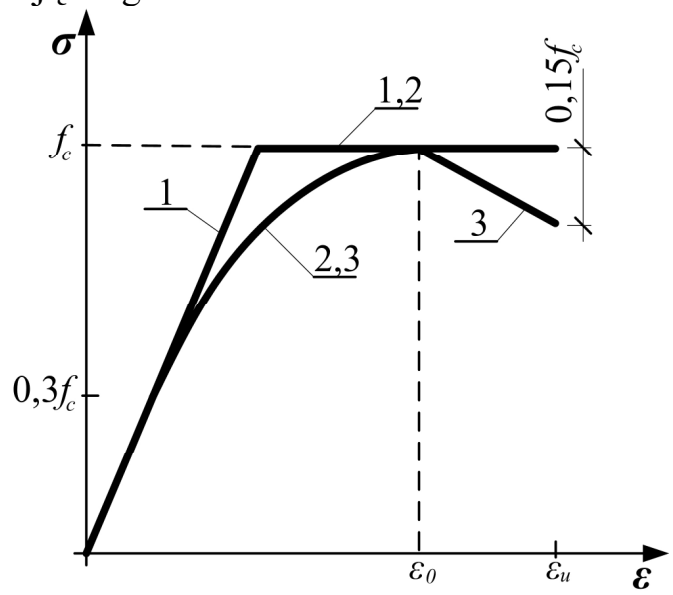

1.2 pav. Gniuždomojo betono įtempių ir deformacijų diagrama

Fig. 1.2. Stress-strain diagram of concrete in compression

Betono stipris gniuždant yra viena svarbiausių mechaninių charakteristikų, pagal kurią nustatoma bendra betono kokybè. Yra pasiūlyta daug gniuždomojo betono įtempių ir deformacijų diagramų. Viena paprasčiausių yra dvitiesė idealiai tamprios-plastinès medžiagos $\sigma-\varepsilon$ diagrama (1.2 pav., 1 kreivè). Vèlesniuose modeliuose buvo imamos itempių-deformacijų kreivès, gautos iš eksperimentinių vienaašio gniuždymo rezultatų. Vidutinio stiprio betonams pirmosios plastinès deformacijos pasireiškia esant itempiams $\sigma_{c}=0,3 f_{c}\left(f_{c}-\right.$ betoninio cilindro arba prizmès stipris gniuždant), o esant maksimaliems itempiams ( $\sigma_{c}=f_{c}$ ) plastinès deformacijos apytikriai yra lygios tampriosioms.

Žemiau pateikiamos kelios dažniau taikomos gniuždomo betono $\sigma-\varepsilon$ diagramos. Hognestad (1955) pasiūlè gniuždomojo betono įtempius ịvertinti taip:

$$
\sigma_{c}=f_{c}\left[2 \frac{\varepsilon_{c}}{\varepsilon_{0}}-\left(\frac{\varepsilon_{c}}{\varepsilon_{0}}\right)^{2}\right],
$$

Collins (1979), Vecchio ir Collins (1981) pasiūlè tokią gniuždomojo betono itempių skaičiavimo formulę: 


$$
\sigma_{c}=\frac{f_{c}}{0,8+170 \varepsilon_{c}}
$$

pagal EC2 (2004) gniuždomojo betono ittempiai apskaičiuojami taip:

$$
\sigma_{c}=f_{c} \frac{1,1 E_{c} \varepsilon_{c} / \varepsilon_{0}-\left(\varepsilon_{c}-\varepsilon_{0}\right)^{2}}{1+\left(1,1 E_{c} \varepsilon_{0} / f_{c}-2\right) \varepsilon_{c} / \varepsilon_{0}},
$$

čia $\sigma_{c}, \varepsilon_{c}-$ gniuždomojo betono ittempiai bei deformacija; $\varepsilon_{0}-$ deformacija atitinkanti standartinio gniuždomo bandinio maksimalius įtempius $f_{c}$.

Saenz (1964) gniuždomojo betono ịtempių ir deformacijų diagramos nustatymui pasiūlè tokią išraišką:

$$
\sigma_{c}=\frac{E_{c} \varepsilon_{c}}{1+\left(\frac{E_{c}}{E_{\mathrm{sec}}}-2\right) \frac{\varepsilon_{c}}{\varepsilon_{c u}}+\left(\frac{\varepsilon_{c}}{\varepsilon_{c u}}\right)^{2}},
$$

Popovics (1973) pasiūlè ịvertinti gniuždomojo betono įtempius pagal formulę:

$$
\sigma_{c}=f_{c} \frac{\left(\frac{\varepsilon_{c}}{\varepsilon_{0}}\right) n}{n-1+\left(\frac{\varepsilon_{c}}{\varepsilon_{0}}\right)^{n}},
$$

čia $n$ nustatomas pagal tokią formulę:

$$
n=\frac{E_{c}}{E_{c}-E_{\mathrm{sec}}},
$$

čia $E_{\mathrm{sec}}-$ kirstinis betono tamprumo modulis apskaičiuojamas taip: $E_{\mathrm{sec}}=f_{c} / \varepsilon_{0}$.

(1.1) ir (1.5) apibūdina kylančiają $\sigma-\varepsilon$ kreivès dali, o krentančioji dalis dažnai imama tiesès formos, kurios pavyzdys pateiktas 1.2 paveiksle ( 3 kreivè). Nors lenkiamų elementų tyrimuose nustatytos ribinès gniuždomojo betono deformacijos $\varepsilon_{u}$ kinta plačiose ribose $0,0025-0,006$, dažniausiai $\varepsilon_{u}$ priimama tarp $0,003-0,004$.

Carreira ir Chu (1986) pasiūlè pilną (iskaitant ir krentančiają dali) $\sigma-\varepsilon$ diagramos formulę: 


$$
\sigma_{c}=\frac{\beta_{c} f_{c}\left(\varepsilon_{c} / \varepsilon_{0}\right)}{\beta_{c}-1+\left(\varepsilon_{c} / \varepsilon_{0}\right)^{\beta_{c} k_{2}}},
$$

čia $\beta_{c}$ ir $k_{2}$-empirinai koeficientai.

Thorenfeldt et al. (1987) pasiūlè (1.7) taikyti stipriesiems betonams, imant:

$$
\beta_{c}=1 /\left(1-f_{c} / \varepsilon_{0} E_{c}\right),
$$

Mansur et al. (1997) prièmè tokią $\beta_{c}$ koeficiento išraišką:

$$
\beta_{c}=1 /\left(1-f_{c} / \varepsilon_{0} E_{c}\right) .
$$

Deformacijai $\varepsilon_{0}$ nustatyti pasiūlyta įvairių formulių. Pagal EC2 (2004) ši deforamcija apskaičiuojama taip:

$$
\varepsilon_{0}=-0,7 f_{c m}^{0,31},
$$

Nicolo et al. (2004) pasiūlè deformacijai $\varepsilon_{0}$ tokią skaičiavimo formulę:

$$
\varepsilon_{0}=0.00076+\left[\left(0,626 f_{c}^{\prime}-4,33\right) \times 10^{-7}\right]^{0,5},
$$

čia $f_{c}$ išreikštas MPa.

\subsubsection{Tempiamasis betonas}

Tempiamojo betono stipris yra sąlyginai mažas. Skirtumas tarp atlaikomų gniuždymo ir tempimo itempių betone gali kisti nuo 10 iki 20 kartų. Tačiau betono stipris tempiant yra vienas pagrindinių veiksnių, kuris nulemia gelžbetoninių konstrukcijų pleišèjimą, deformacijas bei betono ir armatūros itempius.

Pagal EC2 (2004) tempiamasis betono stipris randamas pagal formulę:

$$
\begin{gathered}
f_{c t}=0,30\left(f_{c m}-8\right)^{2 / 3}, \text { kai } f_{c m} \leq 58 \mathrm{MPa}, \\
f_{c t}=2,12 \ln \left(1+f_{c m} / 10\right), \text { kai } f_{c m}>58 \mathrm{MPa},
\end{gathered}
$$

čia $f_{c m}$ yra cilindrinis betono stipris gniuždant.

Ašine jèga tempiamas betonas dirba tampriai, kol ịtempiai neviršyja $0,6 f_{c t}$. Šie įtempiai gali būti laikomi tamprumo riba. Prasidèjęs mikropleišèjimas tampa pastebimas, kai itempiai pasiekia $0,75 f_{c t}$. Pasiekus maksimalius itempius $f_{c t}$ ir juos atitinkančias deformacijas $\varepsilon_{c r}$, tamprios ir plastinès deformacijos apytikriai yra lygios. Viršijus deformacijas $\varepsilon_{c r}$, betonas dar ilgai atlaiko ittempius. Nearmuotų betoninių bandinių ittempių ir deforamcijų diagramos krentančiosios da- 
lies tyrimu autoriai Hughes ir Chapman (1966), Evans ir Marathe (1968), Lemnitzer et al. (2008) nustate, kad maksimalios deformacijos gali viršyti $\varepsilon_{c r}$ net 30 kartu.

Tempiamojo betono elgseną tyré Notkus (1982), Kupliauskas ir Notkus (1987), Kudzys ir Notkus (1978), Liu et al. (2008), Darwin et al (2001), Lemnitzer et al (2008).

\subsubsection{Pleišèjimo modeliai}

Plačiausiai taikomi du betono pleišèjimo modeliai:

Diskrečiųjų plyšių modelis. Śis modelis leidžia įvertinti tai, kad maksimalūs i̇tempiai armatūroje bei gniuždomajame betone yra diskrečiujų plyšių pjūviuose, o tolstant nuo plyšių, įtempiai armatūroje bei gniuždomajame betone mažèja, o tempiamajame betone auga. Diskrečiujuc plyšių modelius taip pat nagrinejo Marcinkovich, Olsen (2003), Pelessone et al. (2003), Shi, Suzuki, Ohtsu (2004). Vienas pagrindinių modelio trūkumu yra tas, kad atsiradus naujiems plyšiams būtina keisti baigtinių elementų tinklą.

Vidutinių plyšių modelis. Laikoma, kad diskretusis plyšys pakeičiamas begale smulkių lygiagrečių plyšeliu, turinčių adekvačią įtaką. Kiekviename apkrovimo lygyje gelžbetoninių elementų deformacijų skirtumas gali būti apskaičiuotas taip:

$$
\Delta \varepsilon=\Delta \varepsilon^{c o}+\Delta \varepsilon^{c r},
$$

čia $\Delta \varepsilon^{c r}$ ir $\Delta \varepsilon^{c o}$ yra atitinkamai plyšiu bei betono deformacijos.

Kaip pasiūlè De Borst ir Nauta (1985) kiekviename naujame apkrovos žingsnyje deformacijų pokyti $\Delta \varepsilon^{c r}$ diskrečiajame plyšyje galima pakeisti į keletą naujų lygiagrečių plyšių. Priklausomybè tarp globalių koordinačių deformacijų pokyčio ir plyšių deformacijų lokaliose koordinatèse gali būti užrašyta taip:

$$
\Delta \varepsilon^{c r}=N \Delta e^{c r},
$$

čia $N$ - deformacijų transformacijų matrica pakeičianti kiekvieno plyšio lokalių deformacijų $\Delta e^{c r}$ pokyti i lokalias.

Itempių pokyčių priklausomybę nuo deformacijų galima užrašyti taip:

$$
\Delta \sigma=D^{c o} \Delta e^{c o},
$$

čia $D^{c o}$ - matrica ivvertinanti pakitusias betono sąvybes.

Vidutinių plyšių modelius tyrè Litton (1974), Rings ir Powell (1986), Bazant ir Gambarova (1980), Gupta ir Maestrini (1989), Vecchio (2000). 
Žinomi keli vidutinių plyšių modeliai, iš kurių galima išskirti fiksuoto bei besisukančio plyšio modelius (1.3 pav.).

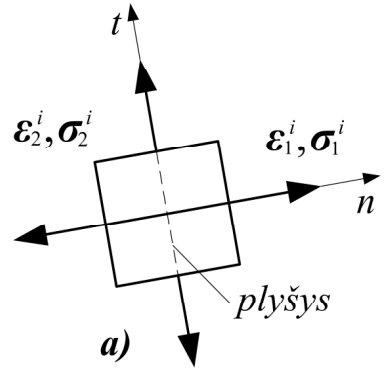

1.3 pav. Pleišèjimo modeliai: (a) atsivèrusio; (b) fiksuoto ir (c) besisukančio plyšio

Fig. 1.3. Cracking models: (a) opened; (b) fixed and (c) rotating crack

Fiksuoto plyšio modelyje (1.3b pav.) plyšio kryptis nusakoma svarbiausiųju itempių kryptimi, susidarant plyšiui. Besisukančio plyšio modelyje (1.3c pav.) svarbiausiujų itempių kryptys sutampa su svarbiausiujų deformacijų kryptimis, o kartu ir su ortotropijos ašimis.

\subsubsection{Armatūros ir betono sukibimas}

Bendras armatūros ir betono deformacijas užtikrina šių medžiagu sukibimas. Dèl labai skirtingų armatūros ir tempiamojo betono deformacinių bei stiprumo sąvybių bendras jų darbas yra sudètingas. Prieš atsirandant plyšiams, armatūros ir betono sukibimą galima laikyti idealiu, tačiau, didejjant apkrovai ir vystantis plyšiams, atsiranda sukibimo defektai, sąlygojantys armatūros praslydimą betone. Sukibimo kokybè priklauso nuo armatūros paviršiaus, betono stiprumo, apkrovimo istorijos, apkrovos krypties, itempių būvio ir kitų faktorių. Pavyzdžiui, veikiant gniuždymo įtempiams skersine kryptimi, maksimalūs tangentiniai įtempiai armatūros ir betono kontakto paviršiuje gali padidèti keletą kartų.

Betono pleišejimo ir sukibimo efektai modeliuojami dvejopai:

1. Tempiamojo betono vidutiniu itempių-deformacijų diagrama, kuria ivertinamas betono pleišèjimas, elgsena tarp plyšių bei armatūros praslydimas. Tokia tempiamojo betono diagrama taikoma vidutinių plyšių modelyje.

2. Armatūros ir tempiamojo betono sukibimo ir praslydimo elgsena. Tokiame modelyje betono ir armatūros sukibimo elgsenai ịvertinti taikomas diskrečiųjų plyšių analitinis modelis. Supleišejusiame elemente armatūros ir betono įtempimai pasiskirsto netolygiai, plyšio vietoje armatūra išlaiko visas veikiančias iražzas, o atkarpose tarp plyšių dalị veikiančių ịtempių perima armatūrą supantis 
betonas. Tolstant nuo plyšio, armatūros ir betono sukibimas gerèja. Todèl tarp plyšiu i darbą isijungia betonas - jame atsiranda tempimo itempimų. Betono ir armatūros sukibimą tyre Watstein ir Seese (1945), Watstein (1947), Lutz ir Gergely (1967), Esfahani ir Rangan (1998) Gambarova et al. (1989), Kwak ir Song (2002), Ruiz et al. (2007), Leutbecher ir Fehlng (2009) Lackner \& Mang (2003), Borosnyói \& Balázs (2005), Eckfeldt (2005), Ruiz et al. (2007), Vollum et al. (2008), Piyasena (2002), Leutbecher \& Fehlng (2009).

\subsubsection{Tempiamojo sustandèjimo modeliai}

Kaip yra žinoma, supleišejusiame gelžbetoniniame elemente plyšio vietoje betono tempimo įtempiai yra lygus nuliui, visą išorinès apkrovos sukeltą irąža atlaiko armatūra. Kadangi plyšyje ir gretimuose pjūviuose armatūra praslysta betono atžvilgiu, kontakto zonoje atsiranda tangentiniai itempiai. Šie itempiai perduodami betonui, todèl jis atlaiko tempimo itempius. Armatūros ir betono sąveika ruožuose tarp plyšių standina gelžbetonini elementą. Supleišejusio betono gebejjimas atlaikyti tempimo itempius vadinama tempiamuoju sustandëjimu (angl. tension stiffening). Pagal Belarbi ir Hsu (1991), Sato et al. (2004), Torres et al. (2004) tempiamojo sustandejjimo efektas susideda iš dviejų komponenčių: pirmoji - supleišèjusiojo tempiamojo betono vidutinių itempių ir deformacijų kreivè, ir antroji - vidutinè plieno įtempių ir deformacijų diagrama. Laikoma, kad ašine jèga apkrautame gelžbetoniniame elemente betono bei plieno vidutinès deformacijos $\varepsilon_{s m}$ yra lygios.

Egzistuoja daug modelių aprašančių gelžbetoninių elementų tempiamojo sustandejjimo efekta, daugelis ju paremti tempiamojo betono vidutinių itempių ir vidutinių deformacijų $\sigma_{t}-\varepsilon_{t}$ diagrama (1.4 pav.).

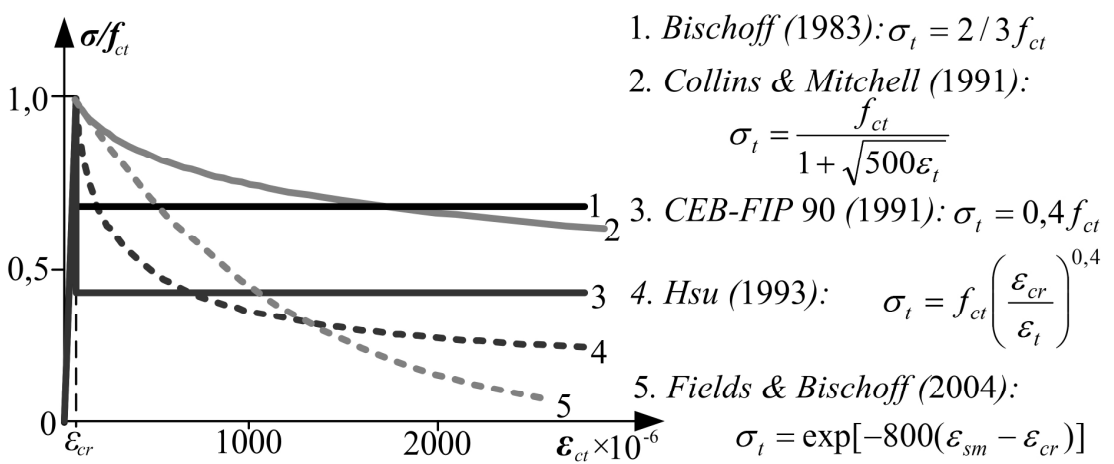

1.4 pav. Tempiamojo sustandèjimo modeliai

Fig. 1.4. Tension stiffening models 
Supleišèjusiojo tempiamojo betono vidutinių itempių ir vidutinių deformacijų diagramą (1.4 pav.) galima suskirstyti ị kylančiają ir krentančiają dalis. Kylančiaja dalimi įvertinama tampri tempiamojo betono elgsena:

$$
\sigma_{t}=E_{c} \varepsilon_{t}, \text { kai } \varepsilon_{t} \leq \varepsilon_{c r},
$$

čia $\sigma_{t}$ ir $\varepsilon_{t}$ yra atitinkamai betono itempiai ir deformacija.

Netiesinei (krentančioji $\sigma_{t}-\varepsilon_{t}$ diagramos dalis 1.4 paveikslas) tempiamojo betono elgsenai charakterizuoti pasiūlyta daug modelių. Careira ir Chu (1986) pasiūlè tempiamojo betono îtempių skaičiavimo formulę analogišką gniuždomojo betono $\sigma-\varepsilon$ diagramai (1.7):

$$
\sigma_{t}=\frac{\beta_{t} f_{c t}\left(\varepsilon_{t} / \varepsilon_{t}\right)}{\beta_{t}-1+\left(\varepsilon_{t} / \varepsilon_{t}\right)^{\beta_{t}}},
$$

čia $\beta_{t}$-empirinis koeficientas.

Hsu (1993) pasiūlè tempiamojo betono ittempius apskaičiuoti taip:

$$
\begin{gathered}
\sigma_{t}=f_{c t}\left(\frac{\varepsilon_{c r}}{\varepsilon_{t}}\right)^{0,4}, \\
f_{c t}=0,311 \sqrt{f_{c}} .
\end{gathered}
$$

Bhide (1986) pasiūlè įvertinti tempiamojo supleišejusio betono vidutinių itempių ir vidutinių deformacijų diagramos krentančiają dalį taip:

$$
\sigma_{t}=\frac{f_{c t}}{1+1000 \varepsilon_{t}(|\Phi| / 90)^{1,5}},
$$

čia $\Phi$ - kampas tarp gelžbetoninio elemento išilginès armatūros bei plyšio krypties, matuojamas laipsniais.

Collins ir Mitchell (1991) pasiūle tokią tempiamojo betono itempių išraišką:

$$
\begin{gathered}
\sigma_{t}=\frac{f_{c t}}{1+\sqrt{500 \varepsilon_{t}}}, \\
f_{c t}=0,33 \sqrt{f_{c}} .
\end{gathered}
$$

Achyutha et al. (1999) tempiamojo sustandejjimo kreivès krentančiają dalị pasiūlè skaičiuoti taip: 


$$
\sigma_{t}=\frac{f_{c k}}{\alpha},
$$

čia $\alpha$ - iš eksperimentinių rezultatų nustatytas koeficientas, apskaičiuojamas taip: $\alpha=-21,67+16,59 \rho+0,66 f_{c k}-0,27 \rho f_{c k}$.

Kai kuriose modeliuose tempiamojo betono itempių ir deformacijų kreivè charakterizuojama koeficientu $\beta$, kuris susietas su pleišejimo deformacija $\varepsilon_{c r}$. Pasiekus vidutinę deformacija $\beta \varepsilon_{c r}$, tempiamojo betono įtempiai tampa lygūs nuliui. Skirtingi autoriai siūlè taikyti ịvairias fiksuotas koeficiento $\beta$ reikšmes. Damjanic ir Owen (1984) siūlè šlyties atveju $\beta$ imti tarp 5 ir 10, o lenkimo atveju - tarp 20 ir 25. Vecchio ir Collins (1986) pasiūlyto koeficiento $\beta$ reikšmè, gauta iš stipriai armuotų elementų eksperimentų rezultatų, apytiksliai buvo lygi 20, Bazant ir Oh (1983) pateikia $\beta=7,7$ reikšmę.

Kaklauskas (2001) pasiūlè tokią tempiamojo sustandèjimo formulę, nustatytą iš lenkiamųjų elementų eksperimentinių duomenų:

$$
\begin{gathered}
\sigma_{t}=0,625 f_{c t}\left(1-\frac{\overline{\varepsilon_{c t}}}{\beta}+\frac{1+0,6 \beta}{\overline{\varepsilon_{c t}}}\right), \overline{\varepsilon_{c t}}=\frac{\varepsilon_{c t}}{\varepsilon_{c r}}, \\
\beta=32,8-27,6 p+7,12 p^{2} .
\end{gathered}
$$

Tempiamujų ir lenkiamuju gelžbetoninių elementų eksperimentiniai tyrimai parode, kad tempiamasis sustandejjimas priklauso ne tik nuo tempiamojo betono stiprio, bet ir nuo armavimo koeficiento, armatūros strypu paviršiaus, skersmens bei kitų veiksnių.

Bichoff (1983) pasiūlytas metodas remiasi bendraja tempiamojo gelžbetoninio elemento pusiausvyros lygtimi:

$$
N=\bar{N}_{s}+\bar{N}_{c},
$$

čia $\bar{N}_{s}$ - vidutinè įrąža, veikianti armatūroje, randama taip: $\bar{N}_{s}=A_{s} E_{s} \varepsilon_{s m} ; \bar{N}_{c}$ - vidutine irąža betone; $A_{s}$ ir $E_{s}$ atitinkamai tempiamos armatūros plotas ir tamprumo modulis; $\varepsilon_{s m}$ - vidutinè santykinè deformacija.

Vidutinè gelžbetoninio elemento tempiamojo betono įrąža $\bar{N}_{c}$ apskaičiuojama taip:

$$
\bar{N}_{c}=A_{c} \bar{\sigma}_{c}=A_{c} \beta f_{c t}=\beta P_{c r},
$$

čia $\bar{\sigma}_{c}$ yra vidutiniai betono itempiai; $P_{c r}$ - pleišèjimo apkrova; $\beta$ - koeficientas ivvertinantis betono sukibimą su armatūra. 
Fields ir Bichoff (2004) pasiūlè tokią tempiamojo sustandèjimo formulę:

$$
\begin{gathered}
\sigma_{t}=\exp \left[-800\left(\varepsilon_{s m}-\varepsilon_{c r}\right)\right], \\
\sigma_{c r}=0,37 \sqrt{f_{c}} .
\end{gathered}
$$

Vidutinè santykinè tempiamojo gelžbetoninio elemento deformacija apskaičiuojama pagal formulę:

$$
\varepsilon_{s m}=\frac{1}{E_{s}}\left(\sigma_{s}-\beta \frac{\sigma_{c r}}{\rho}\right),
$$

čia $\sigma_{s}$ - armatūros įtempiai plyšyje; $\beta$ - koeficientas lygus 0,5 . Vidutinè santykinè tempiamojo gelžbetoninio elemento deformacija gali būti nustatyta taip:

$$
\varepsilon_{s m}=\varepsilon_{s}-\frac{\beta}{n \rho} \varepsilon_{s r}=\frac{\sigma_{s}}{E_{s}}\left(1-\frac{\beta}{1+n \rho} \frac{\sigma_{s r}}{\sigma_{s}}\right),
$$

čia $\sigma_{s r}$ - îtempiai armatūroje elemento pleišejimo pradžioje; $n$ - armatūros ir betono tamprumo modulių santykis: $n=E_{s} / E_{c}$.

Leonhardt (1988) koeficientui $\beta$ nustatyti pasiūlè tokią išraišką: $\beta=\sigma_{s r} / \sigma_{s}$. Išankstinių itempių nuostoliai, apkrovimo tipas ir naujų plyšių atsivèrimas šiame modelyje yra nevertinami. Pritaikius minètų autorių koeficiento $\beta$ skaičiavimo išraišką ir kurią nors iš (1.30) arba (1.31) formulių gaunama:

$$
\varepsilon_{s m}=\left(1-\frac{\beta}{1+n \rho} \frac{\sigma_{s r}^{2}}{\sigma_{s}^{2}}\right)=\varepsilon_{s}\left(1-\frac{\sigma_{s r}^{2}}{\sigma_{s}^{2}}\right)+\frac{\sigma_{s r}}{\sigma_{s}} \varepsilon_{c r} .
$$

Pastaroji formuluote panaudota gelžbetoninių konstrukcijų tempiamojo betono stiprio skaičiavimui CEB-FIP (1978) Model Code. Pagal CEB-FIP (1991) Model Code koeficientas $\beta$ lygus 0,4 .

\subsection{Analiziniai ir empiriniai metodai}

\subsubsection{JAV normos (ACI 318)}

Lenkiamujų gelžbetoninių elementų kreivis išreiškiamas formule $\kappa=M / E I$, čia $E I-$ standis lenkiant. Branson (1963) pasiūlè skirtingiems apkrovimo lygiams taikyti pastovų betono deformacijų moduli (lygu tamprumo moduliui $E_{c}$ ), bet kintamą inercijos momentą $I$. Tampriame būvyje inercijos 
momentas $I_{g}$ nustatomas visam betoniniam skerspjūviui, neịvertinant armatūros. Supleišèjusiam skerspjūviui inercijos momentas $I_{c r}$ apskaičiuojamas neįvertinant tempiamojo betono dalies. Branson (1963) pasiūlè tokią empirinę inercijos momento formuluotę apkrovai, kuri yra atitinkamai didesnè už pleišèjimo, bet mažesnè už armatūros takumą atitinkančias apkrovas:

$$
I_{e}=\left(\frac{M_{c r}}{M}\right)^{3} I_{g}+\left[1-\left(\frac{M_{c r}}{M}\right)^{3}\right] I_{c r},
$$

čia $M_{c r}=f_{r} I_{g} / y_{t}-$ pleišèjimo momentas; $f_{r}=0,643 \sqrt{f_{c}}[\mathrm{MPa}]-$ iš lenkimo bandymų nustatytas tempiamojo betono stipris, neivertinant jo plastinių savybių; $y_{t}$ - atstumas nuo skerspjūvio svorio centro iki tempiamo krašto; $f_{c}-$ cilindrinis gniuždomojo betono stipris.

Teng ir Branson (1993) praplète šio metodo taikymą išankstinio įtempimo atvejui. Ghali (1993) teigè, kad kai kuriems praktinio skaičiavimo atvejams (kai armavimo koeficientas yra mažas arba lenkimo momentas yra nežymiai didesnis už pleišèjimo momenta) ACI metodu apskaičiuoti ịlinkiai gali būti netikslūs.

Atlikti Al-Zaid ir Al-Shaik (1993) eksperimentiniai tyrimai parode, kad koeficiento $\beta$ reikšmè priklauso nuo armavimo koeficiento $\rho$ ir apskaičiuojama pagal pasiūlytą formulę:

$$
\beta=3-0,8 \rho .
$$

Grossman (1981) atliko skirtingų medžiagu ir skerspjūvių sijų parametrinę analizę, nustatydamas efektyvuji inercijos momentą pagal Branson (1963) formulę. Pagal šiuos rezultatus Grossman (1981) patobulino $I_{e}$ skaičiavimo formulę, eliminuodamas būtinybę ịvertinti supleišèjusio skerspjūvio inercijos momentą $I_{c r}$ :

$$
\begin{aligned}
& \frac{I_{e}}{I_{g}}=\left(\frac{M_{c r}}{M}\right)^{2} \leq 1,0, \text { jei } \frac{M}{M_{c r}} \leq 1,6 \text { ir } \\
& \frac{I_{e}}{I_{g}}=0,1\left(\frac{M}{M_{c r}}\right) K^{*}, \text { jei } \frac{M}{M_{c r}}>1,6,
\end{aligned}
$$

čia $K^{*}$ - parametras įvertinantis skerspjūvio matmenis ir medžiagų stiprumo charakteristikas ir apskaičiuojamas taip: 


$$
K^{*}=\left(\frac{d / h}{0,9}\right)\left[\frac{\sqrt{2330 / w_{c}}}{0,4+\left(1,4 M / M_{u}\right)\left(f_{y} / 690\right)}\right],
$$

čia $w_{c}$ - gelžbetonio tūrio svoris $\left(\mathrm{kg} / \mathrm{m}^{3}\right)$ ir $f_{y}$ - armatūros takumo riba (MPa).

Rangan (1982) nagrinèjo stačiakampio skerspjūvio sijų apkrautų išorine apkrova, efektyvuji inercijos momenta, taikydamas Branson (1963) formulę. Pagal tyrimų rezultatus buvo pasiūlytos šios formulès:

jeigu $n \rho>0,045$,

$$
\frac{I_{e}}{b d^{3}}=0,1599 \sqrt{n \rho},
$$

jeigu $n \rho \leq 0,045$,

$$
\frac{I_{e}}{b d^{3}}=0,0019 / n \rho,
$$

čia $n=E_{s} / E_{c}-$ armatūros ir betono tamprumo modulių santykis.

\subsubsection{Murašev metodas}

Rusų mokslininkas Murašev (1950) pasiūlè supleišejusių gelžbetoninių elementų deformacijų apskaičiavimo teorija, pagrisstą plokščiujuc pjūvių prielaida ir eksperimentinių tyrimų rezultatais. Kreivio formulę jis užrašè taip:

$$
\kappa=\frac{\varepsilon_{s m}}{d-x_{m}}=-\frac{\varepsilon_{c m}}{x_{m}},
$$

čia $\varepsilon_{s m}$ ir $\varepsilon_{c m}$ - atitinkamai, betono tempiamojo ir gniuždomojo sluoksnių vidutinès deformacijos; $x_{m}$ - lenkiamojo gelžbetoninio elemento gniuždomosios zonos aukštis, apskaičiuojamas pagal formulę:

$$
x_{m}=\frac{\varepsilon_{c m}}{\varepsilon_{s m}+\varepsilon_{c m}} d .
$$

Gelžbetoninio elemento kreivis gali būti apskaičiuojamas iš vidutinių tempiamosios armatūros arba gniuždomosios zonos betono deformacijų:

$$
\kappa=\frac{\sigma_{s}}{E_{s, r e d}\left(d-x_{m}\right)}-\frac{\sigma_{c}}{E_{c}^{\prime} x_{m}},
$$


čia $E_{s, \text { red }}$ - vidutinis armatūros tamprumo modulis įvertinantis tempiamaji sustandejjimą:

$$
E_{s, r e d}=\frac{E_{s}}{\psi_{s}} .
$$

$E_{c}^{\prime}-$ tampriai-plastinis betono tamprumo modulis gniuždant lygus:

$$
E_{c}^{\prime}=v E_{c},
$$

čia $\psi_{s}$ - vidutinių armatūros deformacijų $\varepsilon_{s m}$ bei armatūros deformacijų plyšio pjūvyje $\varepsilon_{s}$ santykis; $v$ - koeficientas, kuris parodo tampriuju gniuždomojo betono deformacijų dali.

Gelžbetoninio elemento skerspjūvio atsparumo modulis:

$$
W_{t}=\frac{M}{\sigma_{s}}, W_{c}=\frac{M}{\sigma_{c}} .
$$

Pertvarkius lygti (1.43) galima nustatyti lenkiamojo elemento standumą:

$$
B=\frac{E_{s}}{\psi_{s}} A_{s 1}\left(d-x_{m}\right)\left(d-0,5 x_{m}\right) .
$$

Murašev (1950) teorija toliau buvo vystoma Gvozdev (1962) ir jo mokiniu, taip pat ji buvo panaudota sovietinèse projektavimo normose SNiP. Pateiktomis prielaidomis paremtos ir Lietuvos projektavimo normos STR 2.05.05:2005 (2005). Pagal STR 2.05.05:2005 (2005) supleišèjusio gelžbetoninio elemento kreivis išreiškiamas per vidutines tempiamosios armatūros $\varepsilon_{s m}$ ir kraštinio gniuždomojo betono sluoksnio $\varepsilon_{c m}$ deformacijas:

$$
\kappa=\frac{\varepsilon_{s m}+\varepsilon_{c m}}{d},
$$

čia

$$
\begin{gathered}
\varepsilon_{\mathrm{sm}}=\psi_{s} \varepsilon_{s}=\psi_{s} \frac{\sigma_{s}}{E_{s}}=\psi_{s} \frac{M}{z A_{s} E_{s}}, \\
\varepsilon_{\mathrm{cm}}=\psi_{c} \varepsilon_{c}=\psi_{c} \frac{\sigma_{c}}{v E_{c}}=\psi_{c} \frac{M}{\left(1+\varphi_{f}\right) E_{c} z b v d},
\end{gathered}
$$


čia $M$ - išorès momentas; $z$ - skerspjūvio vidaus jëgu petys; $d$ - efektyvus skerspjūvio aukštis; $\psi_{s}$ - vidutinių armatūros deformaciju $\varepsilon_{s m}$ bei armatūros deformacijų plyšio pjūvyje $\varepsilon_{s}$ santykis; $\psi_{c}$ - analogiškas koeficientas kraštiniam gniuždomojo betono sluoksniui; $A_{s}$ - tempiamosios armatūros skerspjūvio plotas, $E_{s}$ ir $E_{c}$ - atitinkamai armatūros ir betono tamprumo moduliai; v koeficientas, kuriuo ịvertinamos gniuždomojo betono plastinès deformacijos; $\varphi_{f}$ - koeficientas, kuriuo ịvertinama gniuždomosios armatūros bei gniuždomosios tejinio skerspjūvio lentynos įtaka.

\subsubsection{Rusijos normos (SP 52-101)}

SP 52-101 (2003) metodas remiasi medžiagu atsparumo bei statybinès mechanikos taisyklèmis. Nesupleišèjusiojo ir supleišèjusiojo gelžbetoninio elemento kreivis apskaičiuojamas taip:

$$
\kappa=\frac{M}{D},
$$

čia $M$ yra išorinių apkrovų sukeltas lenkimo momentas; $D$ - lenkiamojo gelžbetoninio elemento skerspjūvio standumas.

Tamprumo modulis $E_{c 1}$ nesupleišejusiems elementams tempiamoje zonoje apskaičiuojamas taip:

$$
E_{c 1}=0,85 E_{c},
$$

čia $E_{c}$ - betono tamprumo modulis apskaičiuotas pagal SP 52-101 (2003).

Transformuoto nesupleišejusio skerspjūvio inercijos momentas tempiamojoje zonoje yra lygus:

$$
I_{\text {red }}=I+n I_{s 1}+n I_{s 2},
$$

čia $n$ - armatūros ir betono tamprumo modulių santykis; $I$ - elemento betoninio skerspjūvio inercijos momentas apskaičiuotas pagal transformuoto skerspjūvio centrą; $I_{s 1}$ ir $I_{s 2}$ atitinkamai gniuždomosios ir tempiamosios armatūros inercijos momentai nustatyti pagal elemento transformuoto skerspjūvio centrą:

$$
\begin{gathered}
I_{s 1}=A_{s 1}\left(d-y_{c}\right)^{2}, \\
I_{s 2}=A_{s 2}\left(y_{c}-a_{2}\right)^{2},
\end{gathered}
$$


čia $y_{c}$ - atstumas tarp gniuždomosios zonos krašto ir elemento transformuoto skerspjūvio centro; $\alpha_{2}$ - gniuždomosios armatūros apsauginio betono sluoksnio storis.

Transformuoto supleišèjusio skerspjūvio inercijos momentas tempiamojoje zonoje apskaičiuojamas pagal tokią formulę:

$$
I_{\text {red }}=I_{c}+\alpha_{s 2} I_{s 1}+\alpha_{s 1} I_{s 2},
$$

čia $I_{s 1}$ ir $I_{s 2}$ atitinkamai gniuždomosios ir tempiamosios armatūros inercijos momentai, nustatyti pagal elemento transformuoto skerspjūvio centra; $I_{c}$ - elemento betoninio skerspjūvio inercijos momentas, apskaičiuotas pagal transformuoto skerspjūvio centra; $\alpha_{s 1}$ ir $\alpha_{s 2}$ atitinkamai tempiamosios ir gniuždomosios zonos armatūros ir betono tamprumo modulių santykių koeficientai.

Stačiakampio skerspjūvio inercijos momentas apskaičiuojamas pagal formulę:

$$
I_{c}=\frac{b x_{m}^{3}}{3},
$$

čia $x_{m}$ - vidutinis betono gniuždomosios zonos aukštis apskaičiuotas pagal SP 52-101 (2003).

Armatūros ir betono tamprumo modulių santykių koeficientai: gniuždomajai armatūrai:

$$
\alpha_{s 1}=\frac{E_{s}}{E_{c, \text { red }}},
$$

tempiamajai armatūrai:

$$
\alpha_{s 2}=\frac{E_{s, r e d}}{E_{c, r e d}},
$$

čia $E_{s, r e d}$ - vidutinis armatūros tamprumo modulis įvertinantis tempiamojo betono ịtaką tarp plyšių:

$$
E_{s, r e d}=\frac{E_{s}}{\psi_{s}},
$$

čia $\psi_{s}$ ivvertina tempiamojo betono elgseną tarp plyšių ir parodo vidutinę tempiamosios zonos armatūros deformaciją ir apskaičiuojamas taip: 


$$
\begin{gathered}
\psi_{s}=\frac{\varepsilon_{s m}}{\varepsilon_{s, c r}}=1-0,8 \frac{M_{c r}}{M}, \\
M_{c r}=\frac{f_{c t} I_{r e d}}{y_{t}},
\end{gathered}
$$

čia $\varepsilon_{s m}$ - vidutiné tempiamosios armatūros deformacija; $\varepsilon_{s, c r}$ - armatūros deformacija supleišèjusiame skerspjūvyje; $f_{c, t n}$ - betono stipris tempiant pagal SP 52-101 (2003).

\subsubsection{A. Rozembliumo metodas}

Pagal Rozembliumo (1966) skaičiavimo metodiką supleišèjusiame gelžbetoniniame elemente apkrautame trumpalaike išorine apkrova itempių ir įlinkių priklausomybè ivertinama kaip tiesinè - tampri.

Lenkiamojo gelžbetoninio elemento gniuždomosios zonos įtempiai aprašomi trapezoidine diagrama. Išorinès apkrovos lenkimo momentai ir ašinès jègos nagrinejjami skerspjūvio krašto atžvilgiu. Gelžbetoninio elemento kreivis apskaičiuojamas:

$$
\frac{1}{\rho}=\frac{1}{\rho_{0}}(1-k)+\frac{1}{\rho_{I}} k
$$

čia $1 / \rho_{0}-$ supleišèjusio elemento skerspjūvio kreivis; $1 / \rho_{I}-$ nesupleišèjusio skerspjūvio kreivis; $\mathrm{k}$ - koeficientas, ivertinantis betono $\sigma_{c}$ ir armatūros $\sigma_{s}$ itempių diagramas tarp plyšių. Koeficientas k priklauso nuo $\varphi_{s}$ ir $\varphi_{c}$ parametrų, kurie apskaičiuojami pagal tokias išraiškas:

$$
\begin{aligned}
& \varphi_{s}=(1-k)+k \frac{\sigma_{s}^{\prime}}{\sigma_{s}}, \\
& \varphi_{c}=(1-k)+k \frac{\sigma_{c}^{\prime}}{\sigma_{c}} .
\end{aligned}
$$

Analizuodamas kreivio kitimą elemente, Rozembliumas (1966) nustate, kad kreivi pakanka apskaičiuoti tik dviejuose skerspjūviuose - ten, kur lenkimo momentas $M$ turi didžiausią ir mažiausią reikšmes. Kituose pjūviuose kreivis nustatomas interpoliuojant tarp šių ribinių reikšmių, laikant, kad jo kitimas proporcingas momento $M$ kitimui. 


\subsubsection{R. Šimkaus metodas}

R. Šimkus (1998) remiantis eksperimentinių tyrimų rezultatais pasiūlè tokią gelžbetoninio elemento kreivio formulę:

$$
\kappa=a M_{u}\left(\frac{M}{M_{u}}-b\right) / E_{c} I_{t r},
$$

čia parametrai $a$ ir $b$ skaičiuojami elementams be išankstinio ittempimo:

$$
\begin{gathered}
a=3,70 e^{0,19(\alpha-1,75)-2,5(\mu n-0,134)}, \\
b=0,085\left(\ln \alpha+\sqrt{(\ln \alpha)^{2}+2,44}, \alpha=I_{t r} / n A_{s} h^{2},\right.
\end{gathered}
$$

čia $M$ ir $M_{u}$ - atitinkamai yra išorinès apkrovos ir ribinis lenkimo momentai; $I_{t r}$ - transformuoto skerspjūvio inercijos momentas; $\mu=A_{s} / A_{c}-$ armavimo koeficientas; $n$ - armatūros ir betono tamprumo modulių santykis; $h-$ skerspūvio aukštis.

\subsubsection{Kuznycky metodas}

Kuznysky (1975) elemento kreivị siūlo skaičiuoti ịvertinant statmeno pjūvio standumo sumažèjimą iki nulio prieš suyrant elementui. Nagrinèjamos sijos ilgio ruožo vidutinis standumas. Nesupleišèjusio ir supleišejusio ruožų elemento standumas apskaičiuojamas pagal išraiškas:

$$
\begin{gathered}
B_{1}=\gamma E_{c} I_{1}, \\
B_{I I}=B_{1}\left[1-\frac{M}{M_{u}}\left(1-\frac{I_{I I}}{I_{1}}\right) \varphi_{c x} \varphi_{N}\right],
\end{gathered}
$$

čia $\gamma$ - koeficientas, ivertinantis statinès apkrovos pasikartojimus (sijai, apkraunamai pirmą karta, $\gamma=0,67), I_{1}$ ir $I_{I I}$ - atitinkamai pirmojo ir antrojo ruožų inercijos momentai, $\varphi_{c x}$ - koeficientas, ivvertinantis apkrovimo schemą (grynojo lenkimo atveju $\varphi_{c x}=1,25$ ).

Santykinis vidutinis gniuždomosios zonos aukštis II elemento darbo stadijoje apskaičiuojamas, kaip vienas iš lygties sprendinių:

$$
\zeta_{I I}^{2}+\zeta_{I I}\left[2\left(\frac{b_{f}^{\prime}}{b}-1\right) \frac{h_{f}^{\prime}}{d}+2 \mu n\right]-\left[\left(\frac{b_{f}^{\prime}}{b}-1\right)\left(\frac{h_{f}^{\prime}}{d}\right)^{2}+\mu n\right]=0 .
$$


Žinant parametro $\zeta_{I I}$ reikšmę, skaičiuojamas $I_{I I}$ dydis, laikant, kad plyšys kerta visą tempiamają skerspjūvio dalị.

\subsubsection{Rokačiaus metodas}

Rokačius (1975) gniuždomojo betono ịtempių epiūros formą prièmé trikampę, o apskaičiuodamas deformacijas naudoja vidutinį santykini gniuždomosios zonos aukšti $\zeta_{\text {ave }}$, kuris apskaičiuojamas pagal formulę:

$$
\zeta_{\text {ave }}=-A+\sqrt{A^{2}+2 \alpha k}
$$

čia

$$
\begin{gathered}
A=\alpha k_{1}+\left(b_{f}^{\prime}-b\right) h_{f}^{\prime} / b d, \\
\alpha=\mu n / v \varphi_{s}, \\
k_{1}=1+M_{H} / M, \\
M_{H}=N_{02} z, \\
M_{1}=M-N_{02} z .
\end{gathered}
$$

Šiame metode, apskaičiuojant $\zeta_{\text {ave }}$ reikšmę, kai elementą veikia išilginè jèga $N_{02}$, reikia atlikti iteracini skaičiavimo ciklą, iš anksto prièmus $\zeta_{\text {ave }}$ reikšmę. Vidaus jègu peties dydis z statmenojo stačiakampio skerspjūvio pjūvio elementui lygus $0,85 d$. Žinant $\zeta_{\text {ave }}$, nesunku apskaičiuoti vidutines santykines betono ir armatūros deformacijas $\varepsilon_{c, \text { ave }}$ ir $\varepsilon_{s, \text { ave }}$ :

$$
\begin{gathered}
\varepsilon_{c, \text { ave }}=\frac{2 M}{A_{c} z v E_{c}}, \\
\varepsilon_{\text {s,ave }}=\frac{\varepsilon_{c, \text { ave }} x_{\text {ave }}}{d-x_{\text {ave }}} .
\end{gathered}
$$

Elemento kreivis šiuo atveju skaičiuojamas pagal žinomą formulę:

$$
d / \rho=\varepsilon_{c, a v e}+\varepsilon_{s, a v e} .
$$




\subsection{Pirmojo skyriaus rezultatai, išvados ir disertacijos uždavinių formulavimas}

1. Skaičiuojant gelžbetoninių elementų deformacijas didelę itaką turi supleišèjusio tempiamojo betono itempių ir deformacijų diagrama. Deja, Euronormose tokio modelio nèra, o pateikiama tik gniuždomojo betono įtempių ir deformacijų diagrama. Todèl skaitiniais metodais negalima atlikti sudètingu konstrukcijų analizès pagal Euronormų nuostatas.

2. Sparčiai besivystantys skaitiniai metodai grindžiami įvairiais skaičiavimo principais ir gali ịvertinti visus imanomus faktorius: betono pleišejimą, medžiagų fizini netiesiškumą, betono susitraukimo deformaciją bei valkšnuma, armatūros praslydimą ir t. t. Vis dèl to progresas labiau susijęs su matematinio aparato tobulinimu, o ne medžiagų modelių vystymu, tai yra siūlomi tempiamojo sustandèjimo modeliai yra supaprastinti ir ne visada atspindi sudètingą elgseną.

Atsižvelgiant $i$ apibendrinimus, suformuluoti pagrindiniai šio darbo tyrimų uždaviniai:

- taikant Euronormų deformacijų skaičiavimo metodiką bei naudojant skaitini eksperimenta, gauti trumpalaike apkrova veikiamų tempiamuju ir lenkiamujuc gelžbetoninių elementų tempiamojo betono vidutinių itempių ir vidutinių deformacijų diagramas;

- atlikti parametrų turinčių itakos supleišèjusio betono itempių ir deformacijų diagramos formai, analizę;

- pasiūlyti tempiamojo sustandejjimo modelius tempiamiesiems ir lenkiamiesiems gelžbetoniniams elementams;

- naudojant literatūroje paskelbtus eksperimentinius duomenis, atlikti tempiamujų elementų deformacijų ir lenkiamujų elementų ilinkių skaičiavimo tikslumo statistinę analizę, taikant šio darbo ir kitų autorių pasiūlytus modelius ir metodus. 


\section{Tempiamujų gelžbetoninių elementų tempiamojo sustandëjimo modelis}

Šiame skyriuje aptariamas tempiamujų gelžbetoninių elementų tempiamojo sustandèjimo modelio gavimas. Pagal EC2 skaičiavimo metodiką buvo sugeneruotas tempiamuju gelžbetoninių elementų skaitinis eksperimentas. Atlikta svarbiausių faktorių turinčiu įtakos supleišejusio betono vidutinių įtempių ir vidutinių deformacijų diagramai analizè. Pasiūlytas tempiamojo sustandèjimo modelis, atitinkantis Euronormų tempiamujų elementų deformacijų skaičiavimo nuostatas. Skyriaus tematika paskelbtas vienas autoriaus straipsnis (Girdžius, Kaklauskas, Zamblauskaitė 2007). 


\subsection{Deformacijų skaičiavimo metodas pagal Euronormas}

Šiame poskyryje pateikiamas tempiamujų gelžbetoninių elementų Euronormų (EC2) deformacijų skaičiavimo metodas. Pagal ši metodą, apskaičiuojant gelžbetoninio elemento deformacijas, išskiriami nesupleišèję ir supleišeję būviai. Nesupleišejusiame gelžbetoniniame elemente daroma prielaida, kad tarp armatūros ir betono yra idealus sukibimas (nèra praslydimo), t. y. armatūra ir betonas deformuojasi kartu. Supleišèjusiame elemente plyšio vietoje visą tempimo jègą perima armatūra, o tarp plyšių - armatūra ir betonas (2.1 pav.).

Tamprioje stadijoje tempiamojo gelžbetoninio elemento vidutinès deformacijos apskaičiuojamos taip:

$$
\varepsilon_{s m}=\varepsilon_{c m}=\frac{P}{E_{c}\left(A_{c}+n A_{s}\right)} .
$$

Elementas, apkrautas ašine jëga, dirba tampriai tol, kol pasiekia pleišejimo apkrovą:

$$
P_{c r}=f_{c t}\left(A_{c}+n A_{s}\right) \text {, }
$$

čia $f_{c t}$ - tempiamo betono stipris; $A_{c}$ ir $A_{s}$ betono ir armatūros skerspjūviuc plotas; $n=E_{s} / E_{c} ; E_{s}$ - armatūros tamprumo modulis; $E_{c}$ - betono tamprumo modulis.

Kai pasiekiama pleišèjimo apkrova plyšio atsivèrimo vietoje visą tempimo jèga perima armatūra. Staigus ittempių padidejjimas armatūroje sąlygoja žymų vidutinių deformacijų padidejjimą jos apskaičiuojamos pagal tokią išraišką:

$$
\varepsilon_{m}=(1-\xi) \varepsilon_{s 1}+\xi \varepsilon_{s 2},
$$

čia $\varepsilon_{s 1}$ ir $\varepsilon_{s 2}$ - atitinkamai tempiamo gelžbetoninio elemento vidutinès deformacijos tamprioje ir supleišèjusioje stadijose, apskaičiuojamos pagal (2.4) ir (2.5); $\xi$ - pasiskirstymo koeficientas:

$$
\xi=1-\left(\frac{\sigma_{s r}}{\sigma_{s 2}}\right)^{2}\left(\text { čia } \sigma_{s 2}>\sigma_{s r}\right),
$$

čia $\sigma_{s 2}$ - tempiamosios armatūros itempiai, apskaičiuoti pjūviui su plyšiu; $\sigma_{s r}$ - tempiamosios armatūros itempimai, apskaičiuoti pjūviui su plyšiu dèl apkrovos, kuriai esant nagrinejjamame pjūvyje atsiranda plyšių. 


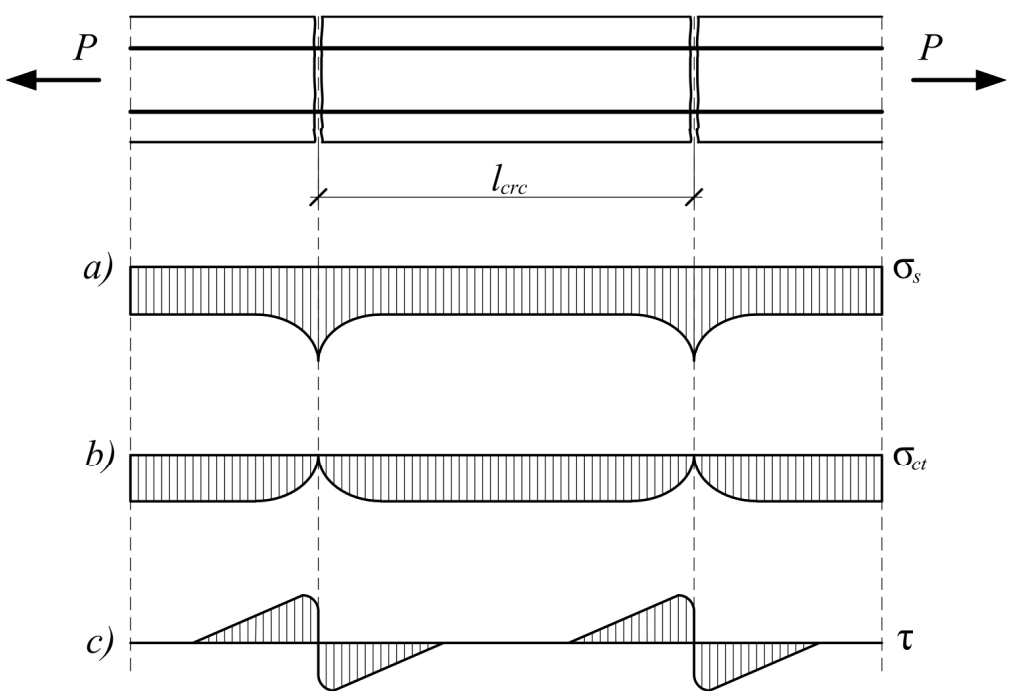

2.1 pav. Centriškai tempiamojo supleišèjusio gelžbetoninio elemento ittempiai:

(a) armatūroje; (b) betone; (c) tangentiniai

Fig. 2.1. Stress in a cracked RC member subjected to uniaxial tension: (a) reinforcement; (b) concrete; (c) tangent

Visiškai supleišèjusio tempiamojo elemento (vidutiniai tempiamojo betono itempiai lygūs nuliui) deformacijos:

$$
\varepsilon_{s 2}=\frac{P}{E_{s} A_{s}} .
$$

Nesupleišèjusio ir supleišejusio gelžbetoninio elemento skerspjūvio vidutinèms deformacijoms apskaičiuoti gali būti taikoma tokia formulè:

$$
\varepsilon_{s m}=\frac{\Delta l}{l}=\varepsilon_{s 2}-\Delta \varepsilon_{s},
$$

čia $\Delta l$ - bendras tempiamo gelžbetoninio elemento pailgejjimas jo ilgyje $l$ nuo išorinès apkrovos $P ; \Delta \varepsilon_{s}$ - tempiamo gelžbetoninio elemento deformacijos tarp plyšių:

$$
\Delta \varepsilon_{s}=\Delta \varepsilon_{s \max } \frac{\sigma_{s r}}{\sigma_{s 2}}
$$

čia $\varepsilon_{s \max }$ - didžiausias tampraus ir supleišèjusio elemento deformacijų skirtumas (2.2 pav). 


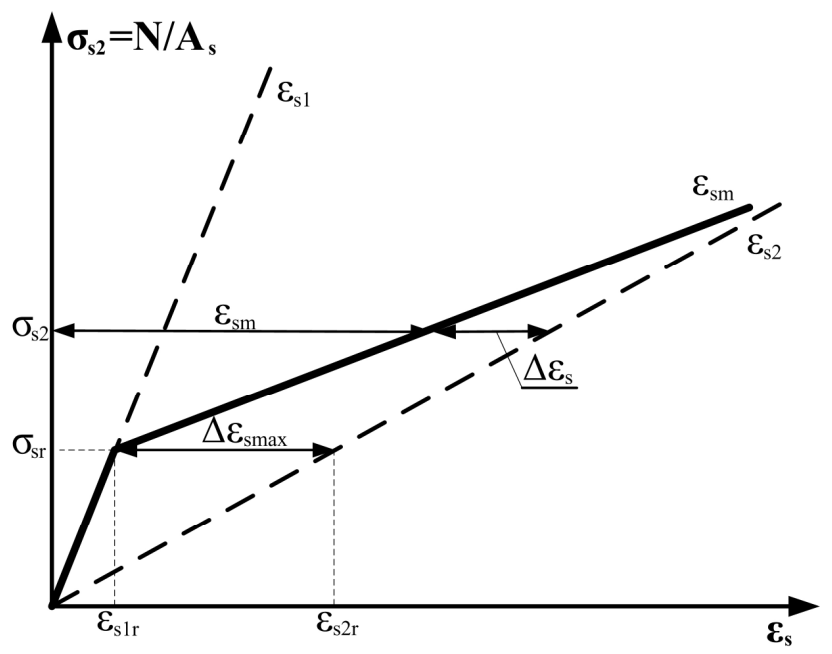

2.2 pav. Gelžbetoninio elemento įtempių-deformacijų diagrama pagal EC2

Fig. 2.2. RC element stress-strain diagram according to the EC2

Vidutinių deformacijų formulè gaunama išraišką (2.7) îstačius i (2.6):

$$
\begin{gathered}
\varepsilon_{s m}=\varepsilon_{s 2}-\varepsilon_{s \max }\left(\frac{\sigma_{s r}}{\sigma_{s 2}}\right)=\varepsilon_{s 2}-\left(\varepsilon_{s 2 r}-\varepsilon_{s 1 r}\right)\left(\frac{\sigma_{s r}}{\sigma_{s 2}}\right), \\
\varepsilon_{s m}=\varepsilon_{s 2}\left[1-\frac{\varepsilon_{s 2 r}}{\varepsilon_{s 2}}\left(\frac{\sigma_{s r}}{\sigma_{s 2}}\right)\right]+\varepsilon_{s 1 r}\left(\frac{\sigma_{s r}}{\sigma_{s 2}}\right), \\
\varepsilon_{s m}=\left(\frac{\sigma_{s r}}{\sigma_{s 2}}\right)^{2} \varepsilon_{s 1}+\left[1-\left(\frac{\sigma_{s r}}{\sigma_{s 2}}\right)^{2}\right] \varepsilon_{s 2},
\end{gathered}
$$

čia $\varepsilon_{s 1 r}$ ir $\varepsilon_{s 2 r}$ - atitinkamai nesupleišèjusio ir supleišejusio būvių tempiamo gelžbetoninio elemento deformacijos atitinkančios įtempius $\sigma_{s r}$. 


\section{2. [tempių ir deformacijų diagramų nustatymo metodika}

Šiame poskyryje pateikiamas tempiamojo sustandèjimo kreivès nustatymas iš tempiamojo gelžbetoninio elemento apkrovos ir deformacijų diagramos. Bet kuriai apkrovimo stadijai gali būti užrašyta jègu pusiausvyros lygtis:

$$
P=N_{s m}+N_{c m},
$$

čia $N_{s m}$ ir $N_{c m}$ - atitinkamai vidutinè įrąža armatūroje ir betone. Žinant deformaciją duotai apkrovai, iražza armatūroje apskaičiuojama taip:

$$
N_{s m}=A_{s} E_{s} \varepsilon_{s m},
$$

čia $\varepsilon_{s m}$ vidutinè armatūros deformacija; $E_{s}$ - armatūros tamprumo modulis; $A_{s}$ - tempiamos armatūros skerspjūvio plotas.

Iš (2.9) ir (2.10) išraiškų nustatome vidutinę iražžą betone:

$$
N_{c m}=P-A_{s} E_{s} \varepsilon_{s m} .
$$

Taikant (2.11) formulę, apskaičiuojami vidutiniai tempiamojo betono įtempiai:

$$
\sigma_{t m}=\frac{P-A_{s} E_{s} \varepsilon_{s m}}{A_{c}}
$$

\subsection{Skaitinis eksperimentas}

Šiame poskyryje pateikiamas tempiamojo sustandejjimo diagramos išvedimas tempiamiesiems gelžbetoniniams elementams. Pagal EC2 deformacijų skaičiavimo metodiką generuojamas skaitinis eksperimentas ir atliekama parametriné bei regresinè analizès. Remiantis skaitinio eksperimento gautais rezultatais, išvedama nauja supleišejusiojo tempiamojo betono vidutinių itempių ir vidutinių deformacijų kreivè. Modelio išvedimas atliekamas dviem žingsniais.

1 žingsnis. Dideliam tempiamujų gelžbetoninių elementų skaičiui (viso 160) pagal EC2 skaičiavimo metodiką (2.1 poskyris) generuojamos apkrovos ir deformacijų diagramos. Skaitiniame eksperimente varijuojami šie parametrai: armavimo koeficientas $(\rho=0,4-3,0 \%)$, betono klasė $(C 20 / 25-C 60 / 75)$ ir armatūros tamprumo modulis $\left(E_{s}=170-210 \mathrm{GPa}\right)$. 
Skaitiniame eksperimente generuotų apkrovos ir deformacijų diagramų ivairių parametrų palyginimo pavyzdžiai pateikti $2.3-2.5$ paveiksluose.
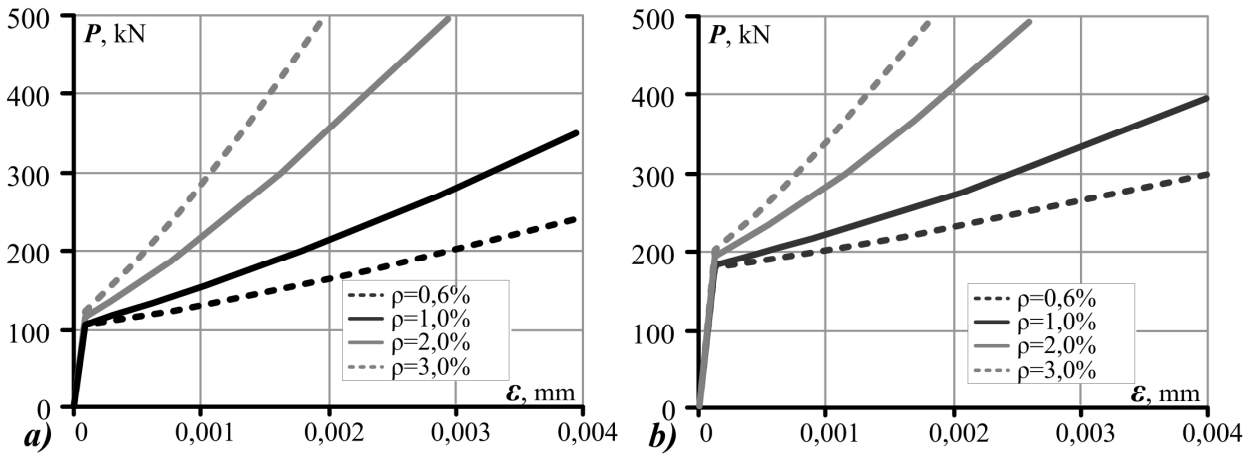

2.3 pav. Apkrovos ir deformacijų diagramos kintant armavimo koeficientui. Betono klasès: (a) $C 20 / 25$ ir (b) $C 60 / 75$

Fig. 2.3. Load-deformation diagrams for ranging reinforcement ratio. Grades of concrete: (a) $C 20 / 25$ and (b) $C 60 / 75$

Analizès, kurių rezultatai pateikti 2.3 paveiksle, kai armatūros tamprumo modulis $\left(E_{s}=200 \mathrm{GPa}\right)$ pastovus. Kaip matyti, armavimo koeficientas turi didelę itaką tempiamu gelžbetoninių elementų deformacijoms, bet beveik neturi itakos pleišejimo apkrovai.
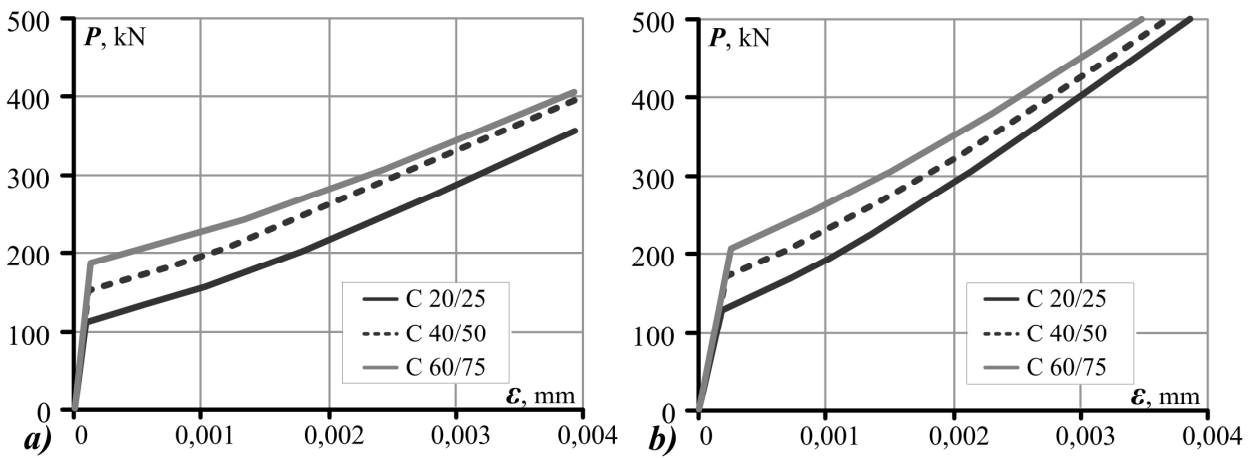

2.4 pav. Apkrovos ir deformaciju diagramos kintant betono klasei. Armavimo koeficientai: (a) $\rho=1,0 \%$ ir (b) $\rho=3,0 \%$

Fig. 2.4. Load-deformation diagrams for ranging grade of concrete. Reinforcement ratio: (a) $\rho=1,0 \%$ and (b) $\rho=3,0 \%$

2.4 paveiksle parodytos apkrovos ir deformacijų diagramos, kai armatūros tamprumo modulis pastovus $\left(E_{s}=200 \mathrm{GPa}\right)$, bet kinta betono klasè. Kaip matyti 
betono klasė turi didelę itaką tempiamujų gelžbetoninių elementų deformacijoms. Silpnai ir vidutiniškai armuotuose elementuose $(\rho \leq 1,0 \%)$ betono klasei kintant nuo $C 60 / 75$ iki $C 20 / 25$ pleišèjimo apkrova sumažèja $46 \%$, o stipriai armuotuose elementuose $(\rho \geq 2,0 \%)$ betono klasei kintant nuo $C 60 / 75$ iki $C 20 / 25$ pleišèjimo apkrova sumažèja $43 \%$.
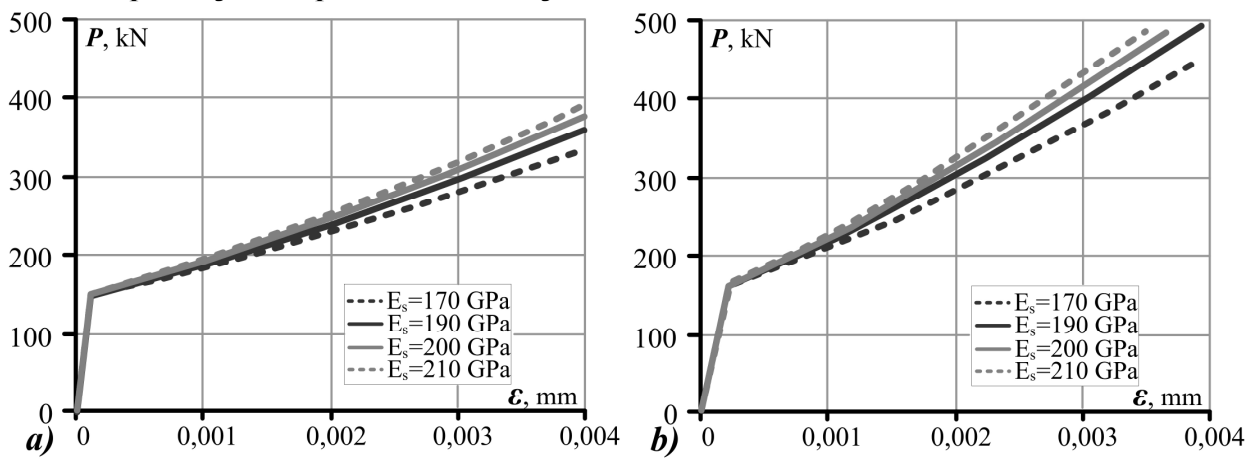

2.5 pav. Apkrovos ir deformacijų diagramos kintant armatūros tamprumo moduliui. Armavimo koeficientai: (a) $\rho=1,0 \%$ ir (b) $\rho=3,0 \%$

Fig. 2.5. Load-deformation diagrams for ranging elastic modulus of reiforcement. Reinforcement ratio: (a) $\rho=1,0 \%$ and (b) $\rho=3,0 \%$

Analizèse, kurių rezultatai pateikti 2.5 paveiksle, buvo imta vienoda betono klasè $(C 20 / 25)$, bet kintantis armatūros tamprumo modulis. Didejjant armatūros tamprumo moduliui tempiamojo gelžbetoninio elemento deformacijos mažèja. Kaip matyti, armatūros tamprumo modulis neturi įtakos pleišèjimo apkrovai.

2 žingsnis. Taikant lygti (2.12), apskaičiuojama vidutinių itempių ir vidutinių deformacijų kreivè kiekvienai apkrovos ir deformacijų diagramai, generuotai pirmajame žingsnyje. Kaip minèta, tempiamojo betono modeli sudaro kylančioji ir krentančioji dalys. Kylančiaja dalimi modeliuojama tampri betono elgsena, o krentančiaja dalimi įvertinamas tempiamojo sustandejjimo efektas.

2.6 paveiksle parodytos skaitiškai nustatytos tempiamojo betono vidutinių itempių ir vidutinių deformacijų diagramos, esant skirtingai betono klasei. Kaip matyti, didejant betono stipriui tempiant didèja tempimo itempiai betone. 

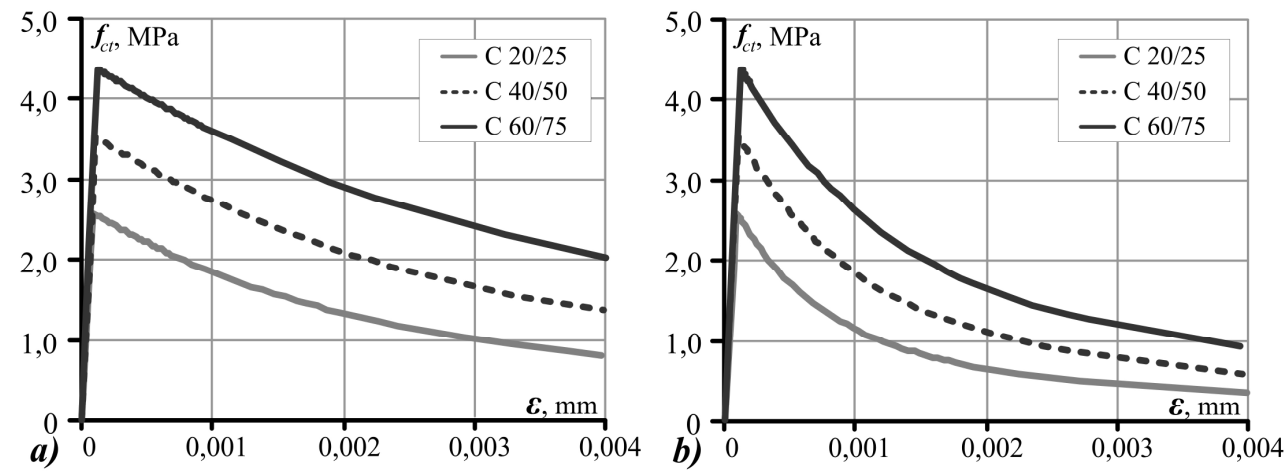

2.6 pav. Skaitiškai nustatytos ittempių ir deformacijų diagramos kintant betono klasei. Armavimo koeficientai: (a) $\rho=1,0 \%$ ir (b) $\rho=3,0 \%$

Fig. 2.6. Numerically derived stress-strain diagrams for varying grade of concrete. Reinforcement ratio: (a) $\rho=1,0 \%$ ir (b) $\rho=3,0 \%$

Išvedant tempimo sustandèjimo modeli parametrinèje analizèje tikslinga tempiamojo betono vidutinių ịtempių ir vidutinių deformacijų diagramas išreikšti santykiniais dydžiais $\sigma / f_{c t}$ ir $\varepsilon / \varepsilon_{c r}$. Tuomet tempiamojo sustandejjimo diagrama, apskaičiuota skirtingiems betono stipriams, praktiškai sutapo (2.7 pav.). Kitos gautos tempiamojo sustandejjimo diagramos, kintant armavimo koeficientui ir armatūros tamprumo moduliui, parodytos 2.8-2.9 paveiksluose.
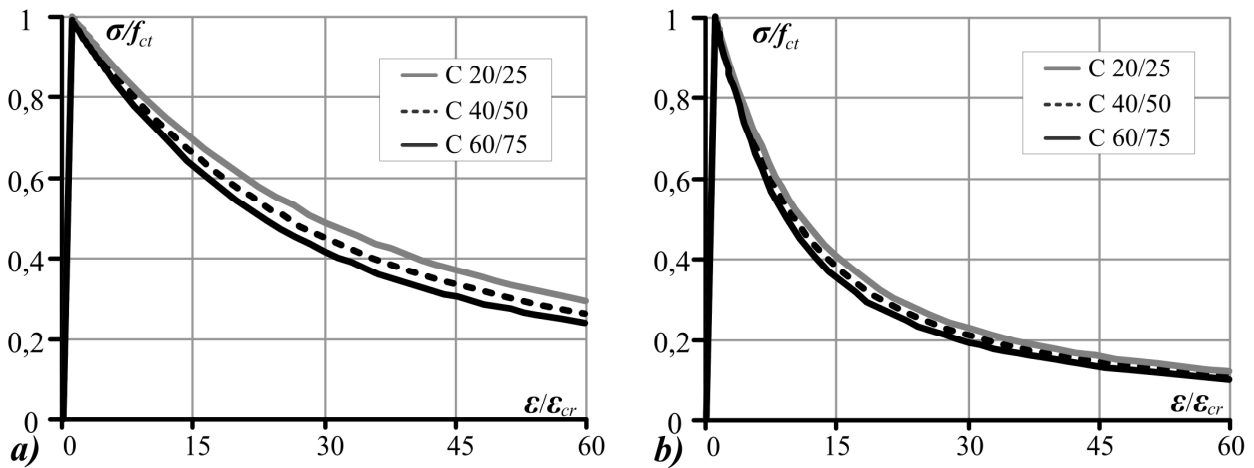

2.7 pav. Skaitiškai nustatytos tempiamojo sustandejjimo diagramos kintant betono klasei. Armavimo koeficientai: (a) $\rho=1,0 \%$ ir (b) $\rho=3,0 \%$

Fig. 2.7. Numerically derived tension stiffening diagrams for varying grade of concrete.

Reinforcement ratio: (a) $\rho=1,0 \%$ ir (b) $\rho=3,0 \%$ 

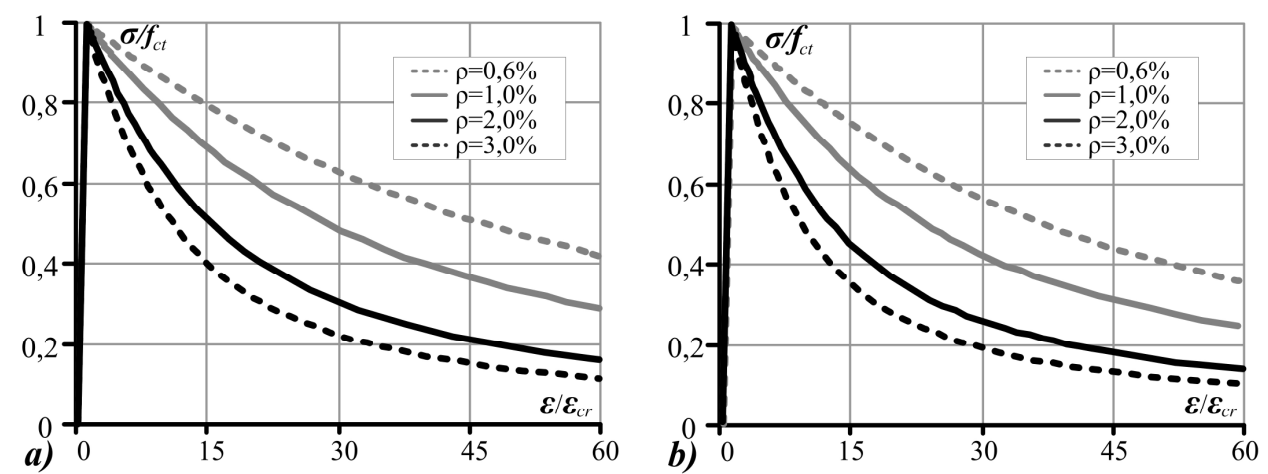

2.8 pav. Skaitiškai nustatytos tempiamojo sustandèjimo diagramos kintant armavimo koeficientui. Betono klasès: (a) C20/25 ir (b) C60/75

Fig. 2.8. Numerically derived tension stiffening diagrams for varying reinforcement ratio. Grades of concrete: (a) $C 20 / 25$ and (b) $C 60 / 75$

Kaip matyti iš 2.8 paveikslo, stipriai armuotų elementų ( $\rho \geq 2,0 \%)$ tempiamasis sustandejjimas yra ženkliai mažesnis lyginant su mažai ir vidutiniškai armuotais elementais ( $\rho \leq 1,0 \%)$. Čia buvo imtas vienodas armatūros tamprumo modulis $\left(E_{s}=200 \mathrm{GPa}\right)$.
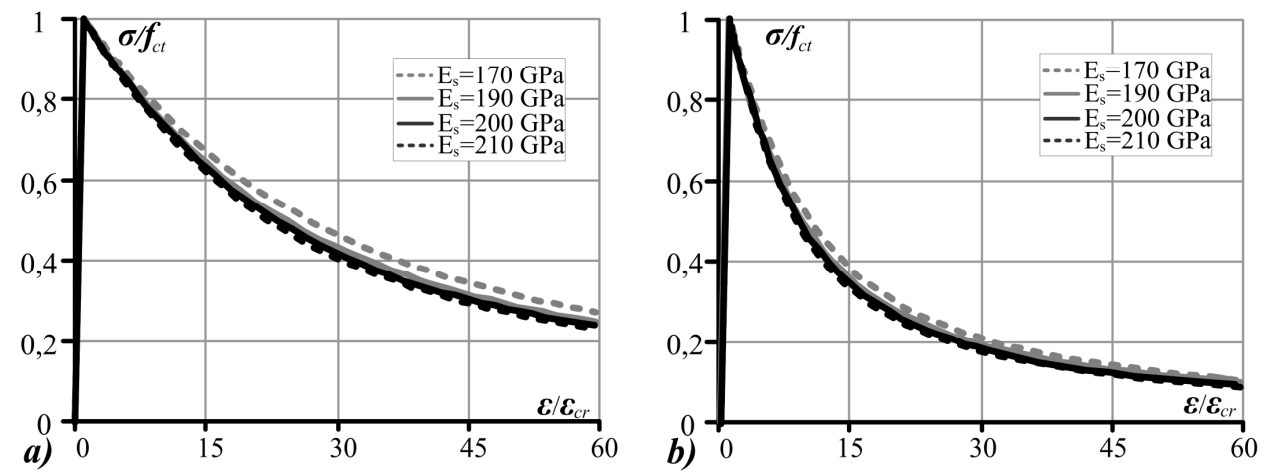

2.9 pav. Skaitiškai nustatytos tempiamojo sustandèjimo diagramos kintant armatūros tamprumo moduliui. Armavimo koeficientai: (a) $\rho=1,0 \%$ ir (b) $\rho=3,0 \%$

Fig. 2.9. Numerically derived tension stiffening diagrams for varying elastic modulus of reiforcement. Reinforcement ratio: (a) $\rho=1,0 \%$ ir (b) $\rho=3,0 \%$

2.9 paveiksle parodytos tempiamojo betono vidutiniu itempių ir vidutiniu deformacijų diagramos, esant pastoviai betono klasei (C20/25), bet skirtingam 
armatūros tamprumo moduliui. Nustatyta, kad armatūros tamprumo modulio itaka tempiamojo sustandèjimo diagramos formai nedidelè.

Siekiant patikrinti, ar tempiamojo sustandejjimo modeliui turi itakos tempiamojo gelžbetoninio elemento aukštis, skirtingų skerspjūvio matmenų $(200 \times 200$ ir $400 \times 400 \mathrm{~mm})$ elementams buvo apskaičiuotos vidutiniu itempių ir vidutinių deformacijų diagramos. Analizè atlikta, esant armavimo koeficientui $(\rho=3,0 \%)$, betono klasei $(C 60 / 75)$ ir armatūros tamprumo moduliui $\left(E_{s}=200 \mathrm{GPa}\right)$. Gautos tempiamojo sustandejimo diagramos tarpusavyje sutapo, jos parodytos 2.10 paveiksle.

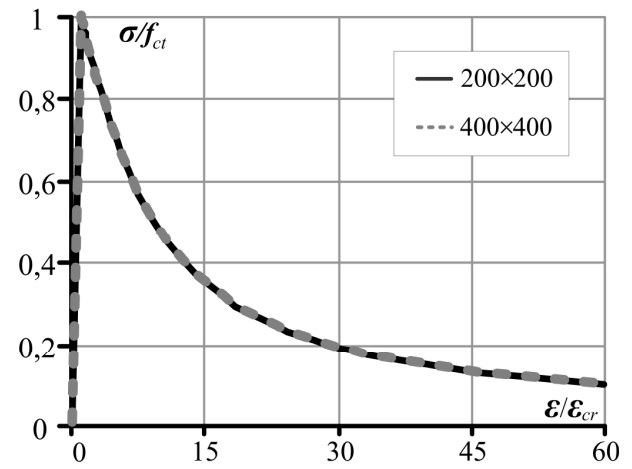

2.10 pav. Skaitiškai nustatytos tempiamojo sustandejjimo diagramos kintant skerspjūviui

Fig. 2.10. Numerically derived tension stiffening diagrams for varying cross-section

\subsection{Tempiamojo sustandèjimo modelis}

Kaip minèta, tempiamojo betono vidutinių itempių ir vidutinių deformacijų diagramą sudaro dvi dalys. Pirmoji ịvertina tampriają elemento elgseną, tempiamojo betono įtempiai apskaičiuojami pagal formulę:

$$
\sigma=\varepsilon E_{c} .
$$

Antrają tempiamojo betono vidutiniu itempių ir vidutinių deformacijų diagramos dalị sudaro tempiamasis sustandejjimas. Atlikus regresinę analizę, nustatyta, kad tempiamajam sustandejjimui didžiausią itaką turi armavimo koeficientas bei armatūros ir betono tamprumo moduliai. Siekiant pasiūlyti kuo paprastesni modeli, buvo priimtas vienas nepriklausomas kintamasis - armavimo koeficiento ir armatūros ir betono tamprumo moduliu santykio sandauga ( $\rho n)$. Tempiamajam sustandejjimui aprašyti, pasiūlyta nesudètinga formulè: 


$$
\sigma_{t}=\frac{f_{c t}}{1+A\left(\frac{\varepsilon}{\varepsilon_{c r}}-1\right)^{1,15}}
$$

čia $A$ - koeficientas, kuris nustatomas taip:

$$
A=0,0022(2 \rho n-1),
$$

čia nustatytas $\rho n$ parametro koreliacijos koeficientas lygus 0,987 , o pasiūlytojo modelio determinacijos koeficientas $-r^{2}=0,991$.

2.11 paveiksle parodytas pagal EC2 metodiką ir pasiūlytaji modeli apskaičiuotų tempiamojo sustandejjimo diagramų palyginimas. Ištisine linija pavaizduotos tempiamojo sustandejjimo diagramos nustatytos pagal pasiūlytaji modeli (2.14), o punktyrine linija apskaičiuotos pagal EC2 metodiką. Kaip matyti, gautieji rezultatai tarpusavyje sutapo.
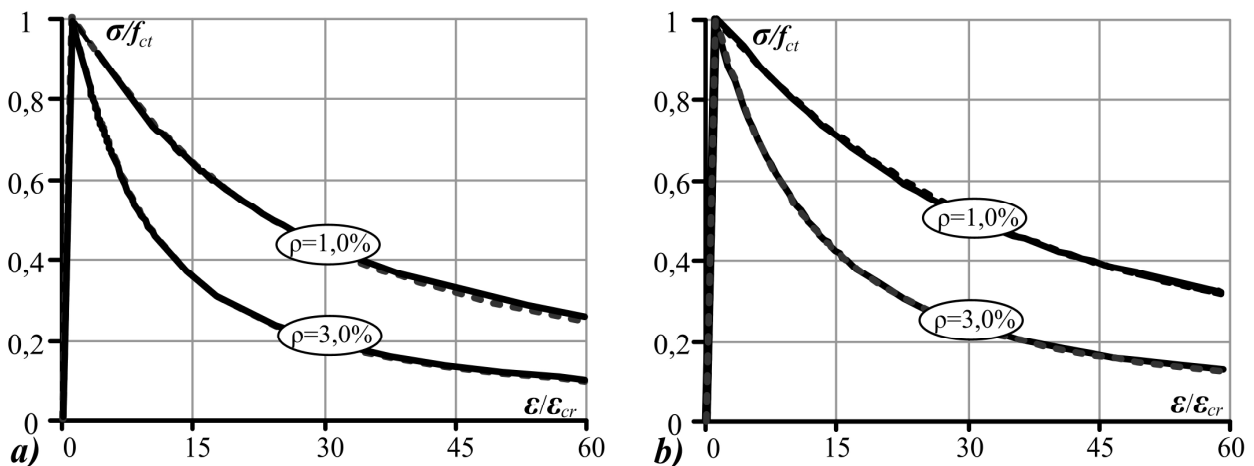

2.11 pav. Pasiūlyto modelio palyginimas su skaitiškai nustatytomis įtempių-deformaciju diagramomis taikant EC2 metodą. Betono klasès: (a) C16/20 ir (b) C60/75

Fig. 2.11. Comparison of numerically derived stress-strain diagrams by proposed model and EC2. Grades of concrete: (a) C16/20 ir (a) C60/75

2.12 paveiksle parodytos pagal EC2 metodiką ir pasiūlytaji modeli apskaičiuotų tempiamuju gelžbetoninių elementų apkrovos ir deformacijų diagramos. Ištisine linija pavaizduotos diagramos nustatytos pagal pasiūlytaji tempiamojo sustandejjimo modeli (2.14), o punktyrine linija pagal EC2 skaičiavimo metodiką. Kaip matyti, gautas geras skaitinio eksperimento bei pasiūlytojo tempiamojo sustandejjimo modelio skaičiavimo rezultatų sutapimas. Čia imta viena betono klasė $(C 20 / 25)$ bei pastovus armatūros tamprumo modulis $\left(E_{s}=200 \mathrm{GPa}\right)$. 


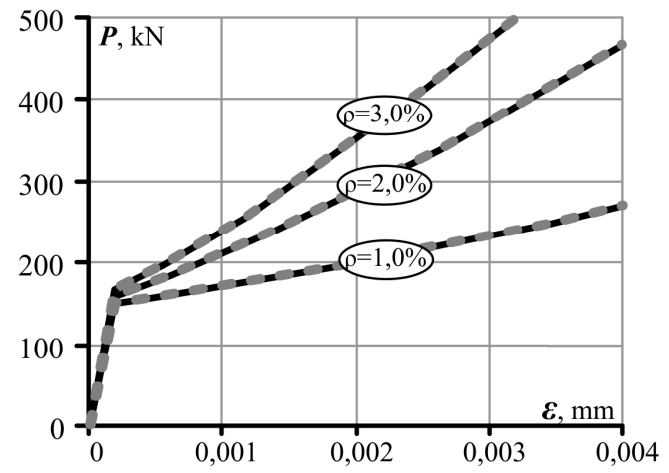

2.12 pav. Apkrovos ir deformacijų diagramos gautos taikant pasiūlytaji modelị ir EC2

Fig. 2.12. Load-deformation diagrams obtained by proposed model and EC2

Pasiūlytas tempiamojo sustandejimo modelis (2.14) gerai įvertina armatūros ir betono tamprumo modulių santykio $\left(n=E_{s} / E_{c}\right)$ kaita. 2.13 paveiksle pavaizduotos tempiamojo betono vidutiniu itempių ir vidutinių deformacijų kreivès, imant armatūros ir betono tamprumo modulių santykius: $n=1 ; 2 ; 4$ ir 6 . Punktyrine linija parodytos pagal EC2 metodiką nustatytos tempiamojo sustandejjimo diagramos, o ištisine linija apskaičiuotos pagal pasiūlytaji modeli (2.14). Kaip matyti, gautieji rezultatai praktiškai sutapo. Nustatytos nedidelès paklaidos mažai ir vidutiniškai armuotiems elementams $(\rho=1,0 \%)$, esant armatūros bei betono tamprumo modulių santykiui $n=1$.
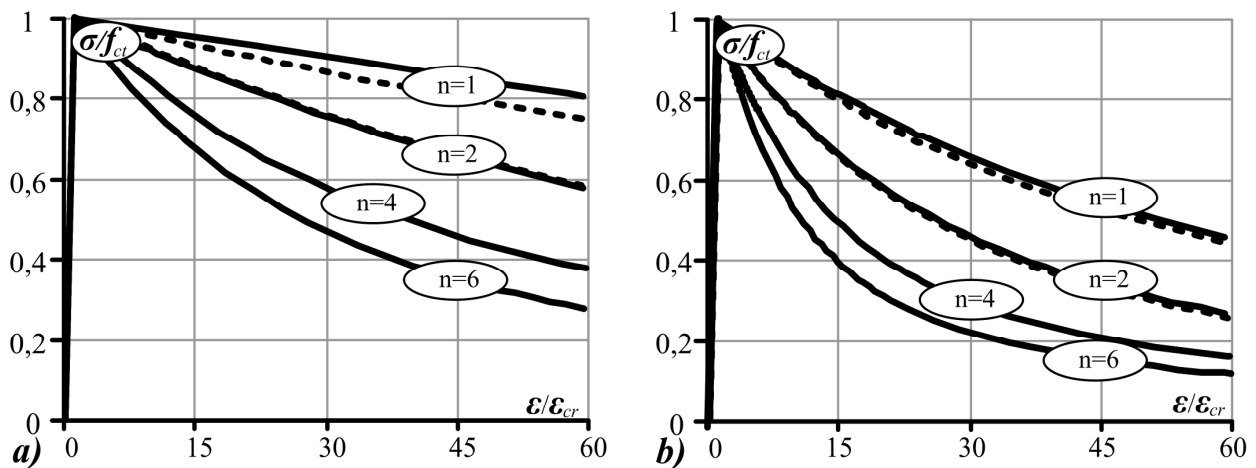

2.13 pav. Skaitiškai nustatytos tempiamojo sustandejjimo diagramos taikant pasiūlytaji modeli ir EC2. Armavimo koeficientus: (a) $\rho=1,0 \%$ ir (b) $\rho=3,0 \%$

Fig. 2.13. Numerically derived tension stiffening diagrams by proposed model and EC2.

Reiforcement ratio: (a) $\rho=1,0 \%$ ir (b) $\rho=3,0 \%$ 


\subsection{Tempiamojo sustandèjimo diagrama pagal CEB- FIP metodą}

Šiame poskyryje pateikiamas kitas, plačiai taikomas, tempiamuju gelžbetoninių elementų deformacijų skaičiavimo CEB-FIP (1990) metodas. Pagal ši metodą buvo apskaičiuotos tempiamuju gelžbetoninių elementų apkrovos ir deformaciju diagramos bei nustatytos tempiamojo sustandejjimo kreivès. Atliktas minètų diagramų palyginimas su EC2 skaičiavimo metodo gautais rezultatais.

Pagal CEB-FIP (1990) metodą tempiamuju gelžbetoniniu elementų deformacijų skaičiavimas suskirstytas i keturis etapus (2.14 pav.):

- nesupleišejęs ruožas:

$$
\varepsilon_{s, m}=\varepsilon_{s, 1}, \text { kai } 0<\sigma_{s} \leq \sigma_{s r 1},
$$

- plyšių formavimosi etapas:

$$
\begin{gathered}
\varepsilon_{s, m}=\varepsilon_{s 2}-\frac{\beta_{t}\left(\sigma_{s}-\sigma_{s r 1}\right)+\left(\sigma_{s r n}-\sigma_{s}\right)}{\sigma_{s r n}-\sigma_{s r 1}}\left(\varepsilon_{s r 2}-\varepsilon_{s r 1}\right), \\
\text { kai } \sigma_{s r 1}<\sigma_{s} \leq \sigma_{s r n},
\end{gathered}
$$

- pleišejjimo stabilizavimasis:

$$
\varepsilon_{s, m}=\varepsilon_{s 2}-\beta_{t}\left(\varepsilon_{s r 2}-\varepsilon_{s r 1}\right) \text { kai } \sigma_{s r n}<\sigma_{s} \leq f_{y k},
$$

- vidutinè tempiamojo gelžbetoninio elemento deformacija pasiekus plieno takumą:

$$
\varepsilon_{s, m}=\varepsilon_{s y}-\beta_{t}\left(\varepsilon_{s r 2}-\varepsilon_{s r 1}\right)+\delta\left(1-\frac{\sigma_{s r 1}}{f_{y k}}\right)\left(\varepsilon_{s 2}-\varepsilon_{s y}\right),
$$

čia $\varepsilon_{s, m}$ - vidutinè deformacija visame tempiamojo gelžbetoninio elemento ilgyje, $\varepsilon_{1}$ ir $\varepsilon_{2}$ - atitinkamai: gelžbetoninio elemento nesupleišejusio ir supleišèjusio ruožų deformacijos, $\varepsilon_{s y}$ - armatūros takumo deformacija, $\sigma_{s r 1}-$ armatūros itempiai supleišèjusiame pjūvyje prie pleišèjimo apkrovos, $\sigma_{s r n}$ - armatūros itempiai plyšyje pleišẻjimo stabilizavimosi etape: $\sigma_{s r n}=1,3 \sigma_{s r 1}$. 


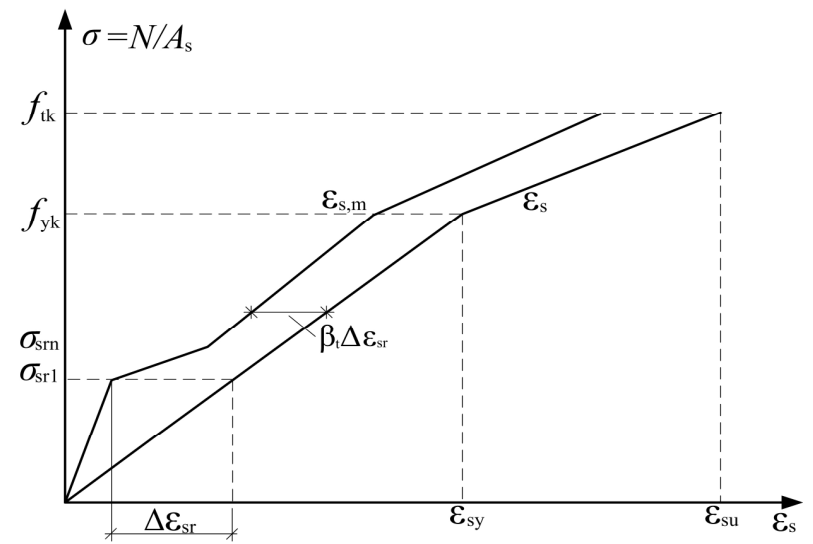

2.14 pav. Itempių ir deformacijų diagrama pagal CEB-FIP

Fig. 2.14. Stress-strain diagram according to the CEB-FIP

Pagal pateiktą tempiamujų gelžbetoninių elementų CEB-FIP (1990) deformacijų skaičiavimo metodiką apskaičiuotos apkrovos ir deformacijų diagramos, kurios buvo palygintos su EC2 skaičiavimo metodo gautais rezultatais (2.15 pav.). Taikant 2.2 poskyryje aptartą metodiką buvo apskaičiuotos tempiamojo sustandèjimo kreivès (2.16 pav.). Kaip matyti, gautų tempiamojo sustandejjimo kreivių forma nesutampa. Pagal CEB-FIP metodą apskaičiuota tempiamojo sustandèjimo diagrama sudaryta iš dviejų dalių: krentančiosios ir tiesės, kurios santykiniai itempiai lygus 0,4 . Šioje analizejje buvo imta betono klasė $(C 20 / 25)$ bei armatūros tamprumo modulis $\left(E_{s}=200 \mathrm{GPa}\right)$.
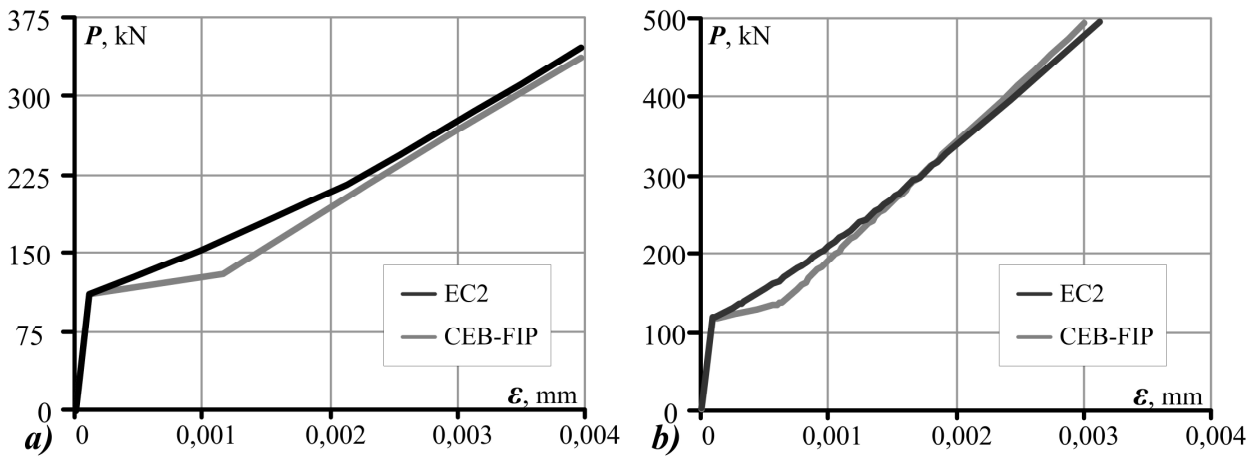

2.15 pav. Apkrovos ir deformacijų diagramos gautos taikant EC2 ir CEP-FIP. Armavimo koeficientai: (a) $\rho=1,0 \%$ ir (b) $\rho=3,0 \%$

Fig. 2.15. Load-deformation diagrams obtained by EC2 and CEP-FIP. Reiforcement ratio: (a) $\rho=1,0 \%$ ir (b) $\rho=3,0 \%$ 

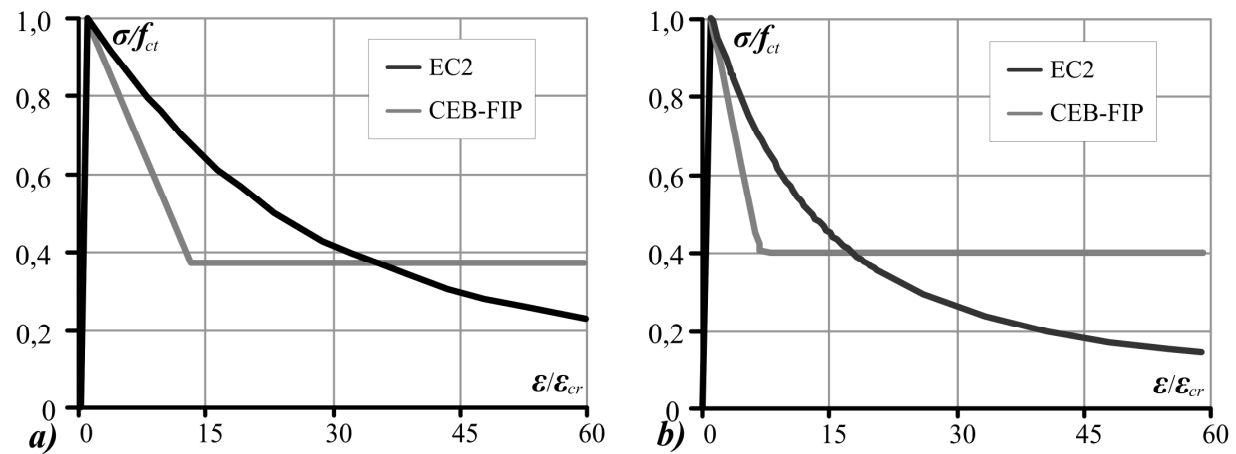

2.16 pav. Skaitiškai nustatytos tempiamojo sustandejjimo diagramos taikant EC2 ir CEPFIP. Armavimo koeficientai: (a) $\rho=1,0 \%$ ir (b) $\rho=3,0 \%$

Fig. 2.16. Numerically derived tension stiffening diagrams by EC2 and CEP-FIP. Reiforcement ratio: (a) $\rho=1,0 \%$ ir (b) $\rho=3,0 \%$

\subsection{Antrojo skyriaus rezultatai ir išvados}

1. Atlikta tempiamojo sustandèjimo modelio, gauto pagal Euronormas, analizè. Nustatyta, kad centriškai tempiamuosiuose gelžbetoniniuose elementuose betono tempiamojo sustandejjimo diagrama priklauso nuo betono stiprio, armavimo koeficiento bei armatūros ir betono tamprumo modulių santykio.

2. Pasiūlytasis tempiamujuc elementų tempiamojo sustandèjimo modelis gerai atitinka Euronormų nuostatas, nustatytos iki $1 \%$ deformacijų skaičiavimo paklaidos. 



\section{Lenkiamuju gelžbetoninių elementų tempimo sustandèjimo modelis}

Šiame skyriuje pateikiamas tempiamojo sustandejjimo modelio išvedimas lenkiamiesiems gelžbetoniniams elementams. Pagal EC2 metodiką buvo apskaičiuotos momentų-kreivių diagramos. Taikant sluoksnių metodą iš skaitinio eksperimento rezultatų nustatytos tempiamojo betono vidutinių itempių-deformacijų diagramos ir atlikta parametrinè analizè. Remiantis gautais rezultatais pasiūlytas naujas, atitinkantis Euronormų deformacijų skaičiavimo nuostatas, lenkiamujuc gelžbetoninių elementų tempiamojo sustandejjimo modelis. Skyriaus tematika paskelbti trys autoriaus straipsniai (Kaklauskas, Bačinskas, Girdžius, Sokolov 2008; Kaklauskas, Gribniak, Girdžius 2011; Girdžius, Kaklauskas, Zamblauskaitè, Jakubovskis 2011). 


\subsection{Momentų-kreivių skaičiavimas pagal EC2 metodą}

Šiame poskyryje pateikiamas lenkiamuju gelžbetoninių elementų EC2 kreivių skaičiavimo metodas. Pagal ši metodą apskaičiuojant gelžbetoninio elemento kreivius, išskiriami nesupleišèję ir supleišèję būviai. Nesupleišèjusiame būvyje betonas ir armatūra deformuojasi tampriai, tuo tarpu supleišejusiame visus tempimo įtempius perima armatūra. Supleišèjusio elemento vidutinis kreivis randamas pagal formulę:

$$
\kappa_{m}=(1-\xi) \kappa_{1}+\xi \kappa_{2},
$$

čia $\kappa_{1}$ ir $\kappa_{2}$-atitinkamai nesupleišèjusio ir supleišejusiojo lenkiamojo gelžbetoninio elemento kreiviai; $\xi$ - pasiskirstymo koeficientas:

$$
\xi=1-\beta\left(\frac{M_{c r}}{M}\right)^{2},
$$

čia $\beta$ - koeficientas, kuriuo ivvertinama apkrovos trukmè ir pobūdis: 1 - trumpalaikei apkrovai, 0,5 - ilgalaikei arba ciklinei apkrovai.

Kreiviai $\kappa_{1}$ ir $\kappa_{2}$ apskaičiuojami pagal formules:

$$
\begin{gathered}
\kappa_{1}=\frac{M}{E_{c} I_{1}}, \\
\kappa_{2}=\frac{M}{E_{c} I_{2}},
\end{gathered}
$$

čia $I_{1}$ ir $I_{2}$ - atitinkamai nesupleišèjusiojo ir supleišejusiojo lenkiamojo gelžbetoninio elemento redukuoti inercijos momentai; $E_{c}$ - betono tamprumo modulis.

Lenkiamojo gelžbetoninio elemento pleišejimo momentas pagal EC2 metodiką apskaičiuojamas pagal išraišką:

$$
M_{c r}=W_{1} f_{c t},
$$

čia $f_{c t}$ - betono stipris tempiant; $W_{1}$ - skerspjūvio atsparumo momentas tamprioje stadijoje. 


\subsection{Trumpas metodo aprašymas tempiamojo sustandejjimo kreivei išvesti iš lenkiamuju gelžbetoninių elementų momentų-kreivių diagramų}

Šiame poskyryje pateikiamas Kaklausko (2001) pasiūlytas integralinis metodas supleišèjusio tempiamo betono vidutinių itempių ir vidutinių deformacijų diagramoms nustatyti iš lenkiamų gelžbetonių elementų eksperimentinių duomenų. Tokia diagrama apima betono pleišèjimo, betono su armatūra sukibimo tarp plyšių, armatūros praslydimo betone ir betono susitraukimo efektus.

Integralinis modelis apima tradicines armatūros ir gniuždomo betono įtempių ir deformacijų diagramas bei integralinę tempiamo betono fizinę kreivę. Terminu ,integralinis“ taip pat pažymima, kad fizinis modelis skirtas ne įtempių ir deformacijų būviui nustatyti tam tikrame elemento pjūvyje arba taške, o elemento ruožo, kaip atskirų pjūvių visumos, vidutinių deformacijų (ir įtempių) apskaičiavimui.

\subsubsection{Taikytos prielaidos} darbą:

Taikomos šios prielaidos, ivvertinančios lenkiamų gelžbetoninių elementų

a) plokščiuju pjūvių hipotezè, t. y. deformacijos skerspjūvio aukštyje kinta tiesiškai;

b) armatūros ir betono sukibimas laikomas idealiu. Armatūros praslydimas betone, atsirandantis prie didesnių apkrovų, ivertinamas tempiamo betono fizine priklausomybe;

c) fizinis modelis pagrịstas vidutinių plyšių modeliu, t. y. skaičiavimuose taikomi vidutiniai itempiai bei vidutinès deformacijos;

d) visiems tempiamo betono sluoksniams galioja ta pati itempių ir deformacijų diagrama. Analogiška prielaida taikoma visiems gniuždomo betono sluoksniams.

Pastaroji prielaida yra mažiau tiksli tempiamam betonui, nes, esant duotai deformacijai, supleišejusio betono vidutiniai itempiai yra didesni sluoksniuose prie armatūros, nei sluoksniuose labiau nutolusiuose nuo armatūros (3.1 pav.). 

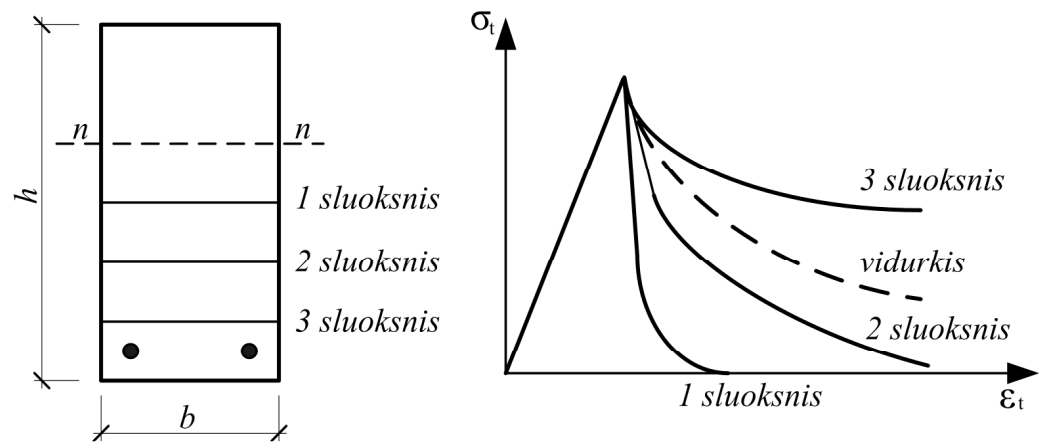

3.1 pav. Skirtingais atstumais nuo armatūros strypų nutolusių tempiamo betono sluoksnių vidutinès įtempių ir deformacijų diagramos

Fig. 3.1. Average stress-strain relationships for cracked concrete in tension for different fibres of a cross-section

\subsubsection{Pagrindinès geometrijos ir pusiausvyros lygtys}

Nagrinejjamas dvipusiai armuotas be išankstinio itempio gelžbetoninis elementas (3.2 pav.), apkrautas lenkimo momentu (skersinès jègos neivertinamos). Žinant dviejų skirtingų sluoksnių deformacijas lenkiamo gelžbetoninio elemento kreivis gali būti apskaičiuojamas taip:

$$
\kappa=\frac{\varepsilon_{t}-\varepsilon_{c}}{h}=\frac{\varepsilon_{s}-\varepsilon_{c}}{d},
$$

čia $\varepsilon_{t}, \varepsilon_{c}-$ kraštinių betono sluoksnių (atitinkamai tempiamo ir gniuždomo) vidutinès deformacijos; $\varepsilon_{s}$ - tempiamos armatūros vidutiné deformacija; h, datitinkamai skerspjūvio aukštis ir naudingasis aukštis.

Neutraliosios ašies padètis gali būti nustatyta iš sąlygos:

$$
y_{c}=\frac{\varepsilon_{c}}{\varepsilon_{t}-\varepsilon_{c}} h=\frac{\varepsilon_{c}}{\varepsilon_{s}-\varepsilon_{c}} d .
$$

Bet kurio sluoksnio deformacija ịvertinama pagal tokią formulę:

$$
\varepsilon_{z, i}=\kappa y_{i},
$$

čia $y_{i}-i$-ojo sluoksnio atstumas neutraliosios ašies atžvilgiu. Laikomasi tokios ženklų taisyklès, kad tempimo deformacija bei $y_{i}$ reikšmès sluoksniams, esantiems žemiau neutraliosios ašies, būtų teigiamos. 

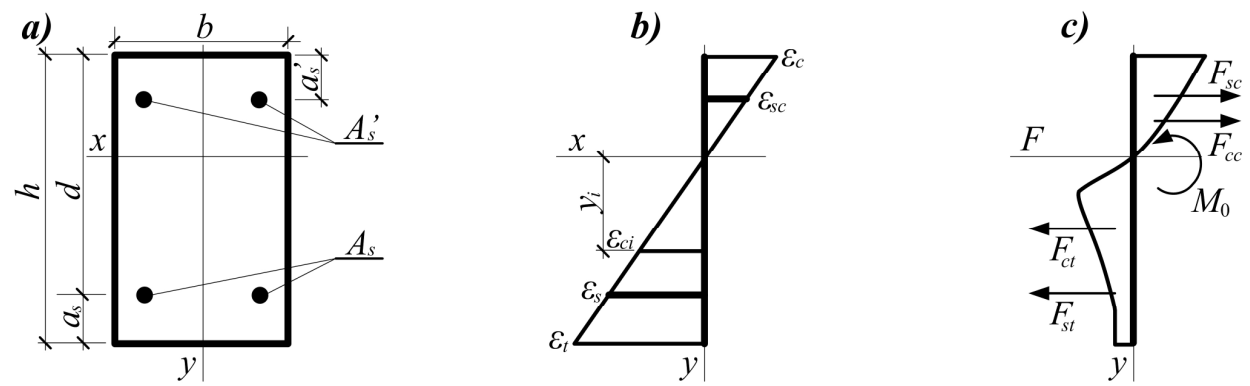

3.2 pav. Lenkiamo gelžbetoninio elemento skerspjūvio deformacijos ir įrąžos:

(a) dvipusiai armuoto elemento skerspjūvis;

(b) deformacijų diagrama; (c) vidaus jègos ir išorès momentas

Fig. 3.2. Reinforced concrete beam section subjected to bending moment: (a) doubly reinforced section; (b) strain compatibility; (c) internal forces and external bending moment

Lenkiamo gelžbetoninio elemento vidaus jègu pusiausvyros lygtys:

$$
\begin{gathered}
F_{c c}+F_{s c}+F_{c t}+F_{s t}=0, \\
M_{c c}+M_{s c}+M_{c t}+M_{s t}-M_{0}=0,
\end{gathered}
$$

čia $F$ - vidaus jègos; $M$ - vidaus jègų momentai neutraliosios ašies atžvilgiu; $M_{0}$ - išorès lenkimo momentas. Pirmoji indekso raidè atitinka betoną ( $c$ concrete) arba tempimą ( $t$ - tension). Vidaus jègų ženklai tokie pat, kaip atitinkamų deformacijų.

\subsubsection{Supleišèjusio betono i̇tempių-deformacijų diagramų nustatymo metodas, taikant lenkiamuju gelžbetoninių elementų eksperimentinius duomenis}

Turimi tokie lenkiamų gelžbetoninių elementų eksperimentiniai duomenys: a) momento ir vidutinių deformacijų diagrama kraštiniam gniuždomo betono sluoksniui; b) momento ir vidutinių deformacijų diagrama kraštiniam tempiamo betono sluoksniui; c) armatūros itempių ir deformacijų diagrama. Turint (a) ir (b) diagramas, iš (3.6) ir (3.8), gali būti nustatyta neutralios ašies padètis ir bet kurio sluoksnio deformacija. Bet kuriai apkrovos pakopai gali būti išspręstos dvi pusiausvyros lygtys - (3.9) ir (3.10), apskaičiuojant dviejų nežinomujų reikšmes. Vidutinių jègų apskaičiavimui patogu naudoti skerspjūvị sudalinta ị sluoksnius. Žinant armatūros deformacija, jos ittempiai bei atstojamoji nesunkiai nustatomi iš itempių ir deformacijų diagramos. Išorès momentas $M_{o}$ ir visų tempiamojo bei gniuždomojo betono sluoksnių deformacijos taip pat yra žinomi. Nežinomieji 
tèra - tempiamo bei gniuždomo betono itempiai, tačiau tiek tempiamoje tiek gniuždomoje skerspjūvio dalyje yra daug sluoksnių, todèl turimų pusiausvyros lygčiu (3.9) ir (3.10) nepakanka tų sluoksnių itempiams apskaičiuoti.

Nežinomujų skaičius gali būti sumažintas iki dviejų tokiu būdu. Nežinomaisiais laikomi kraštutinių sluoksnių gniuždomo ir tempiamo betono itempiai. Skaičiavime apkrova didinama pakopomis. Pirmajai apkrovos pakopai apskaičiuojami vidutiniai tempiamo ir gniuždomo betono įtempiai, atitinkantys eksperimentines kraštinių sluoksnių deformacijas. Gautos įtempių ir deformacijų diagramos taikomos visiems kitiems gniuždomo ir tempiamo betono sluoksniams, kurių deformacijos yra mažesnès už kraštinių sluoksnių deformacijas. Antrajai apkrovos pakopai nustatomos naujos kraštinių sluoksnių itempių prieaugių reikšmès, o gautosios itempių ir deformacijų diagramos taikomos mažiau deformuotiems sluoksniams. Tokiu būdu didèjančia tvarka nustatomos gniuždomo ir tempiamo betono vidutinių îtempių ir deformacijų diagramos. Pasiūlytojo metodo esmé parodyta 3.3 paveiksle, kur eksperimentiniai taškai pažymèti apskritimais.
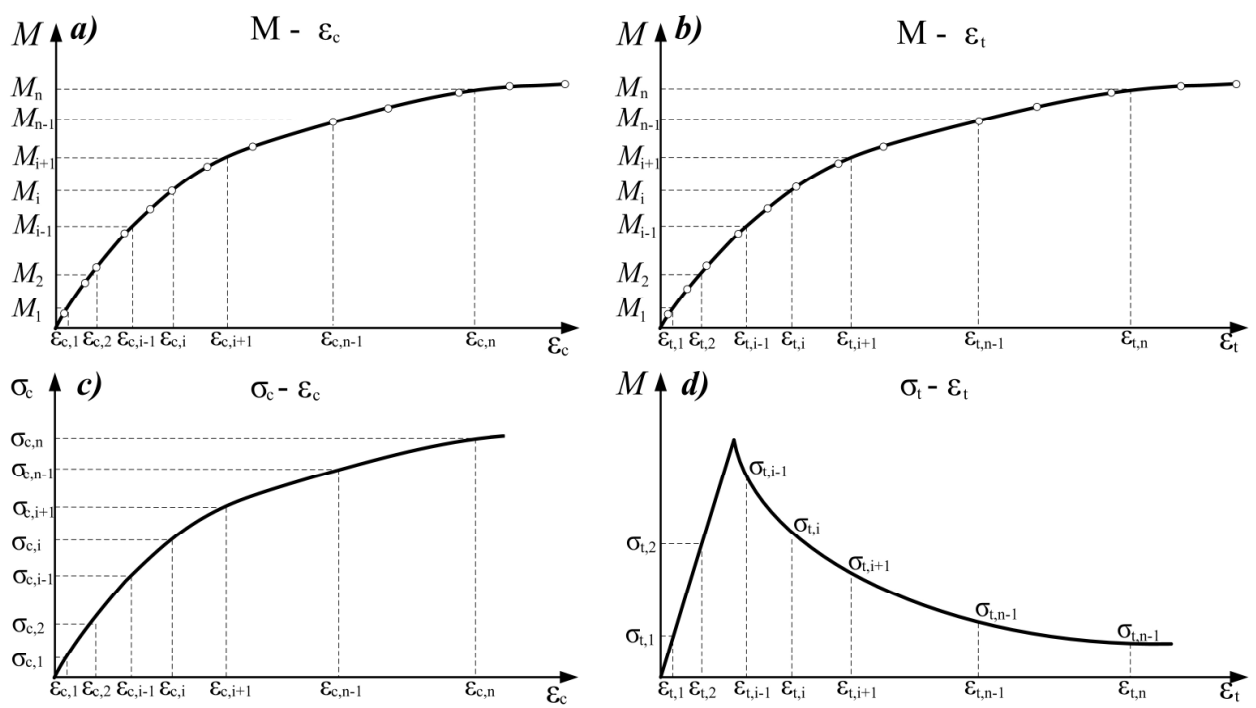

3.3 pav. „Eksperimentinès“ momentų ir deformacijų diagramos: kraštiniams (a) gniuždomo ir (b) tempiamo betono sluoksniams; apskaičiuotos vidutinių itempių ir deforrmacijų kreivès (c) gniuždomam ir (d) tempiamam betonui

Fig. 3.3. „Experimental“ moment strain curves: for extreme fibre of (a) compressive and (b) tensile concrete; computed average stress-strain relation for concrete in (c) compression and (d) tension 
Eksperimentinius taškus sujungę tiesiomis atkarpomis, gautume netolydžias momentų ir deformacijų diagramas. Tokiomis diagramomis apskaičiuotos medžiagos $\sigma-\varepsilon$ kreivès būtu trūkios. Todèl eksperimentinès momentų ir deformacijų diagramos, taikant kompiuterinę programą MATLAB, skaitiškai interpoliuojamos, t. y. padaromos tolydžiomis. Interpoliuotos kreivès parodytos ištisinèmis linijomis 3.3a ir 3.3b paveiksluose. Skaičiavimas atliekamas užduotam apkrovos pakopų skaičiui $\mathrm{n}$. Kad apskaičiuotosios itempių ir deformacijų kreivès (3.3c ir 3.3d pav.) taip pat būtų tolydžios, $n$ turi būti pakankamai didelis. Momento prieaugis $\Delta M=M_{\max } / n$, o momentas $i$-ajam prieaugiui $M_{i}=i \cdot \Delta M$, kur $M_{\max }$ - maksimali momento reikšmè eksperimentinèse momentų ir deformacijų diagramose.

Kraštinio gniuždomo betono sluoksnio deformacijos (3.3a pav.):

$$
\varepsilon_{c, i}=\varepsilon_{c, 1}, \varepsilon_{c, 2} \ldots \varepsilon_{c, n-1}, \varepsilon_{c, n},
$$

bei kraštinio tempiamo betono sluoksnio deformacijos (3.3b pav.):

$$
\varepsilon_{t, i}=\varepsilon_{t, 1}, \varepsilon_{t, 2} \ldots . \varepsilon_{t, n-1}, \varepsilon_{t, n},
$$

atitinkančios momentus:

$$
M_{i}=M_{1}, M_{2} \ldots . M_{n-1}, M_{n},
$$

nustatomos skaitiškai interpoliuotoms $M-\varepsilon$ kreivèms.

Vaizdumo ir skaičiavimo supaprastinimo dèlei galima imti ne pastovų, o kintamą skerspjūvio sluoksnių skaičių. Betono sluoksnių skaičius tiek tempiamoje, tiek gniuždomoje zonoje imamas lygiu apkrovos pakopos numeriui i $(i \leq n)$. Gniuždomo betono zonos j-ojo sluoksnio $(j \leq i)$ storis nustatomas ir sąlygos, kad jo kraštinių sluoksnių deformacija $\varepsilon_{c, j}$ būtų pastovi visoms apkrovos pakopoms:

$$
t_{c, j, i}=y_{c, i}\left|\frac{\varepsilon_{c, j}-\varepsilon_{c, j-1}}{\varepsilon_{c, i}}\right| .
$$

Analogiškai nustatomas tempiamo betono zonos j-ojo sluoksnio storis:

$$
t_{c, j, i}=\left(h-y_{c, i}\right) \frac{\varepsilon_{t, j}-\varepsilon_{t, j-1}}{\varepsilon_{t, j}},
$$

čia $y_{c, i}$ - gniuždomosios zonos aukštis, esant $i$-ajai apkrovos pakopai; indeksas c pažymi gniuždomą, o $t$ - tempiamą betoną. 
Didejjant apkrovos pakopos numeriui, sluoksnių skaičius didejja, o jų storis mažeja. Gniuždomo ir tempiamo betono sluoksnių skaičius pakopai $(i=1)$ imama po vieną gniuždomo ir tempiamo betono sluoksni, kurių kraštinių sluoksnių deformacijos lygios atitinkamai $\varepsilon_{c, 1}$ ir $\varepsilon_{t, 1}$ (3.4b paveikslas). iš pusiausvyros lygčių (3.9) ir (3.10) apskaičiuojami atitinkami įtempiai $\sigma_{c, 1}$ ir $\sigma_{t, 1}$. Antrajai apkrovos pakopai $(t=1)$ imama po du gniuždomo ir tempiamo betono sluoksnius. Pirmujų sluoksnių $(j=1)$ deformacijos $\varepsilon_{c, 1}$ ir $\varepsilon_{t, 1}$ bei itempiai $\sigma_{c, 1}$ ir $\sigma_{t, 1}$ yra žinomi. Antrujų sluoksnių ( $j=2$ ) kraštinès deformacijos yra lygios $\varepsilon_{c, 2}$ ir $\varepsilon_{t, 2}$, o jas atitinkantys įtempiai $\sigma_{c, 2}$ ir $\sigma_{t, 2}$ nustatomi iš pusiausvyros lygčių.

Bendrasis atvejis $i$-ajai apkrovos pakopai parodytas $3.4 \mathrm{~d}$ paveikslas. Itempių $\sigma_{c, i}$ ir $\sigma_{t, i}$ nustatymui pusiausvyros lygtyse (3.9) ir (3.10) nariai, $F_{c c} F_{c t}$, $M_{c c}$ ir $M_{c t}$ suskaidomi į du komponentus:

$$
\begin{gathered}
F_{c c, i-1}+\Delta F_{c c, i}+F_{s c}+F_{c t, i-1}+F_{c t, i}+F_{s t}=0, \\
M_{c c, i-1}+\Delta M_{c c, i}+M_{s c}+M_{c t, i-1}+M_{c t, i}+M_{s t}+M_{0}=0,
\end{gathered}
$$

čia $F_{c c, i-1}, F_{c t, i-1}, M_{c c, i-1}$ ir $M_{c t, i-1}$ - itempių, veikiančių betone, atstojamosios ir jų momentai, nustatyti atitinkamai betono zonai, neįvertinus kraštinio sluoksnio $(j=1,2 \ldots . i-1) \Delta F_{c t, i}, \Delta F_{c c, i}, \Delta F_{c c, i}, \Delta M_{c t, i}, \Delta M_{c c, i}-$ tas pats, ivertinus tik kraštinius sluoksnius $(j=1)$.

I-ajai apkrovos pakopai $F_{c c, i-1}, F_{c t, i-1}, M_{c c, i-1}$ ir $M_{c t, i-1}$ gali būti nesunkiai nustatyti, nes tiek gniuždomo, tiek tempiamo betono įtempiai atitinkamiems sluoksniams $(j=1,2 \ldots . . i-1)$ buvo apskaičiuoti ankstesnèse apkrovos pakopose. Likusieji keturi betono atstojamujų ir jų momentų komponentai galo būti išreikšti per itempių prieaugius $\Delta \sigma_{c, i}$ ir $\Delta \sigma_{t, i}$ kraštiniuose sluoksniuose (3.4d paveikslas):

$$
\begin{gathered}
\Delta F_{c c, i}=b t_{c, i, i}\left(\sigma_{c, i-1}+\frac{1}{2} \Delta \sigma_{c, i}\right), \\
\Delta M_{c c, i}=b t_{c, i, i}\left[\sigma_{c, i-1}\left(y_{c, i}-\frac{1}{2} t_{c, i, i}\right)+\frac{1}{2} \Delta \sigma_{c, i}\left(y_{c, i}-\frac{1}{3} t_{c, i, i}\right)\right], \\
\Delta F_{c t, i}=b t_{t, i, i}\left(\sigma_{t, i-1}+\frac{1}{2} \Delta \sigma_{t, i}\right)
\end{gathered}
$$




$$
\Delta M_{c t, i}=b t_{t, i, i}\left[\sigma_{t, i-1}\left(t-y_{c, i}-\frac{1}{2} t_{t, i, i}\right)+\frac{1}{2} \Delta \sigma_{t, i}\left(y_{c, i}-\frac{1}{3} t_{t, i, i}\right)\right] .
$$
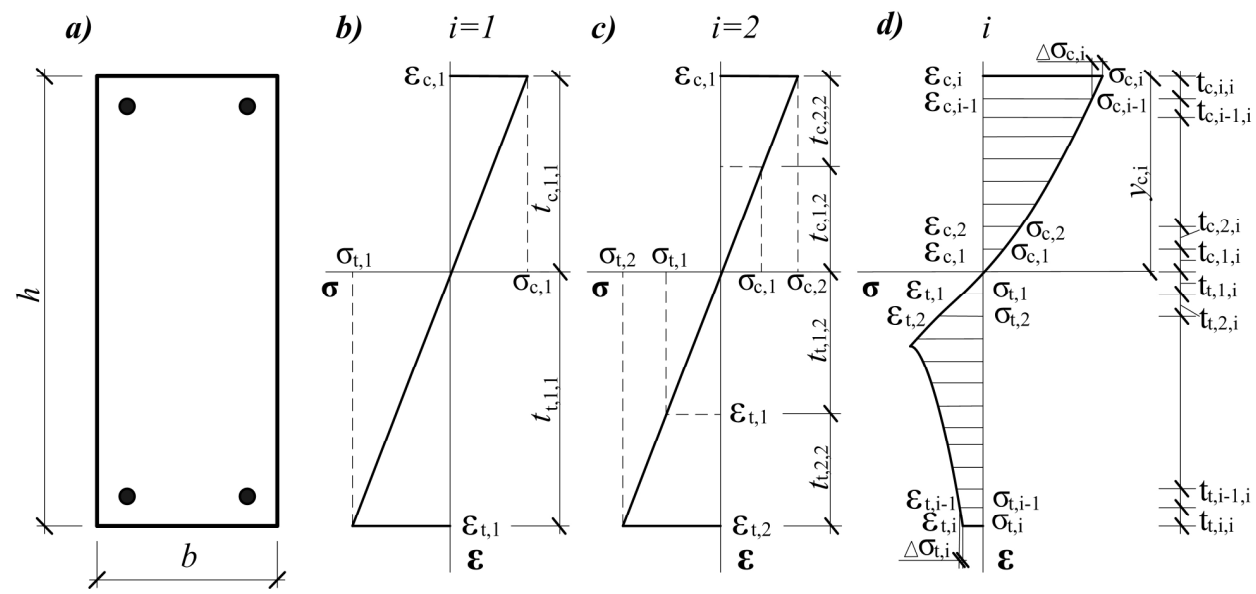

3.4 pav. Betono sluoksnių skaičius ịvairioms apkrovos pakopoms bei atitinkamai įtempiai ir deformacijos

Fig. 3.4. Stresses and strains and concrete layer assumption in a cross-section for different load stages

Itempių prieaugiai $\Delta \sigma_{c, i}$ ir $\Delta \sigma_{t, i}$ nustatomi tiesiogiai iš pusiausvyros lygčių (3.16) ir (3.17). Tuomet betono įtempiai apskaičiuojami iš šiu priklausomybių:

$$
\begin{gathered}
\sigma_{c, i}=\sigma_{c, i-1}+\Delta \sigma_{c, i}, \\
\sigma_{t, i}=\sigma_{t, i-1}+\Delta \sigma_{t, i} .
\end{gathered}
$$

Metodas buvo patikrintas statiškai, taikant tokią testavimo procedūrą. Nagrinejjamas lenkiamas stačiakampio skerspjūvio elementas, kurio visi geometriniai duomenys bei armatūros, gniuždomo ir tempiamo betono medžiagų diagramos buvo žinomi. Visų pirma, taikant sluoksnių metoda, apskaičiuojamos momentų ir deformacijų diagramos. Vèliau, turint šias diagramas, pasiūlytuoju metodu apskaičiuojamos tempiamo bei gniuždomo betono įtempių ir deformacijų diagramos. Testavimas laikomas pavykusiu, jei imtos ir apskaičiuotos medžiagų itempių ir deformacijų diagramos sutampa. Atlikus testavimą, buvo gautas puikus šių kreivių sutapimas. 


\subsection{Skaitinis eksperimentas}

Šiame poskyryje pateikiamas tempiamojo sustandejimo modelio išvedimas lenkiamiesiems stačiakampio skerspjūvio gelžbetoniniams elementams. Pagal EC2 kreivių skaičiavimo metodika generuojamas skaitinis eksperimentas ir atliekama parametrinè bei regresinè analizès. Remiantis skaitinio eksperimento gautais rezultatais, išvedama nauja tempiamojo sustandejjimo kreive. Kaip ir tempiamiems elementams (2.3 poskyris) išvedimas atliekamas dviem žingsniais.

1 žingsnis. Pagal EC2 skaičiavimo metodiką generuojamas skaitinis eksperimentas, momentų ir kreivių diagramos (viso 450 elementu). Visų lenkiamujų elementų aukštis buvo $400 \mathrm{~mm}$, o plotis $-200 \mathrm{~mm}$. Analizuojami elementai turejo skirtinga armavimo koeficientą $(\rho=0,2-2,0 \%)$, betono klasę $(C 20 / 25-$ $C 60 / 75)$, armatūros tamprumo moduli $\left(E_{s}=170-210 \mathrm{GPa}\right)$ bei naudingojo skerspjūvio aukščio santykį su visu skerspjūvio aukščiu $(d / h=0,75-0,975)$.

Skaitiniame eksperimente generuotu momentų ir kreivių diagramų ivairių parametrų palyginimo pavyzdžiai pateikti $3.5-3.8$ paveiksluose.
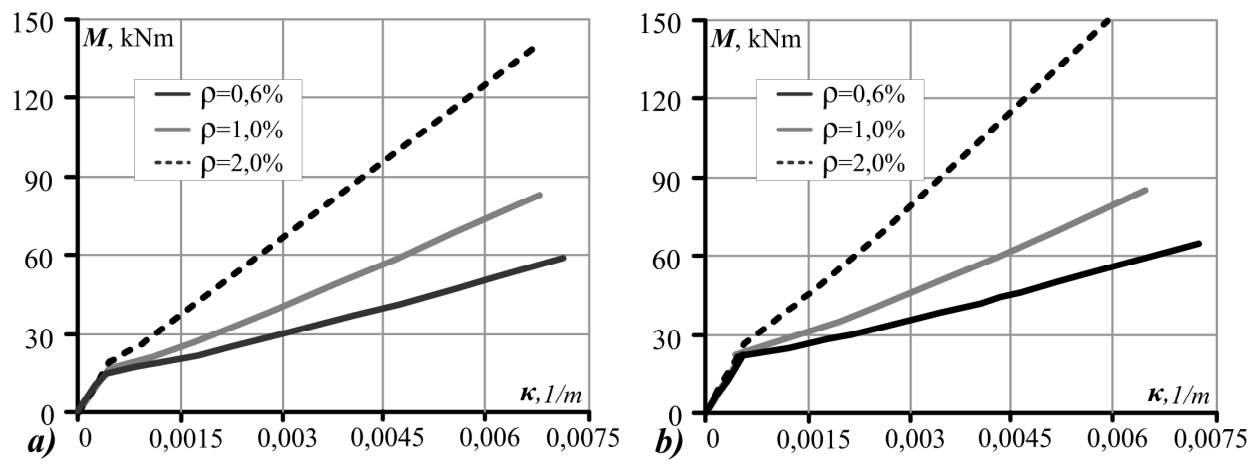

3.5 pav. Momentu-kreivių diagramos kintant armavimo koeficientui. Betono klasės: (a) $C 20 / 25$ ir (b) $C 40 / 50$

Fig. 3.5. Moment-curvature diagrams for ranging reinforcement ratio. Grades of concrete: (a) $C 20 / 25$ ir (b) $C 40 / 50$

3.5 paveiksle parodytos momentų ir kreivių diagramos, kai armatūros tamprumo modulis $\left(E_{s}=210 \mathrm{GPa}\right)$ ir efektyvusis skerspjūvio aukštis $(d=0,37 \mathrm{~m})$ pastovūs, bet kinta armavimo koeficientas. Kaip matyti, armavimo koeficientas turi didelę itaką lenkiamujų gelžbetoninių elementų kreiviams, bet beveik neturi itakos pleišejjimo momentui. 

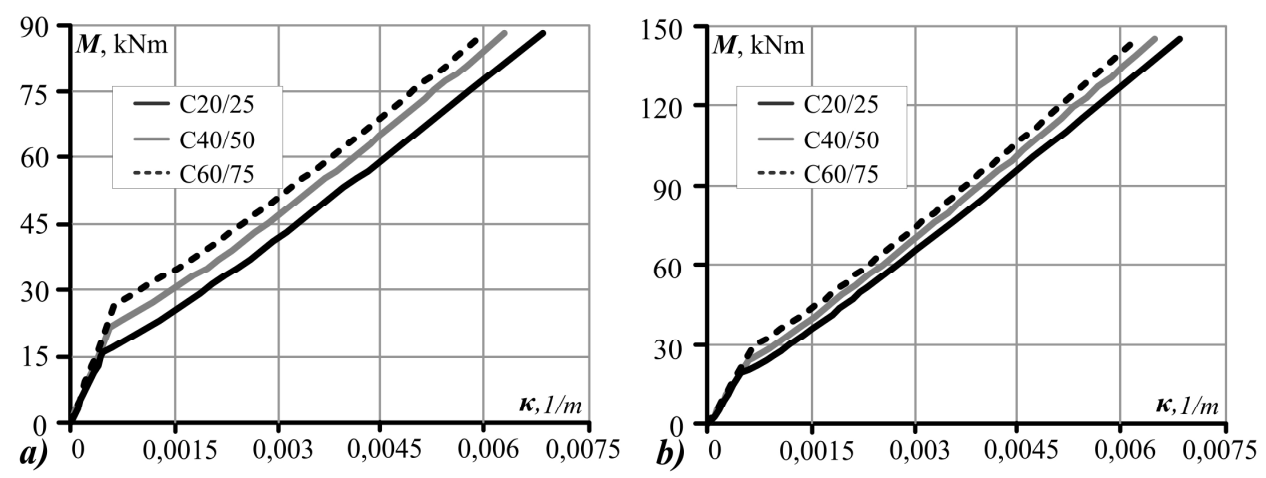

3.6 pav. Momentų-kreivių diagramos kintant betono klasei. Armavimo koeficientai:

(a) $\rho=1,0 \%$ ir (b) $\rho=2,0 \%$

Fig. 3.6. Moment-curvature diagrams for ranging grade of concrete. Reinforcement ratio: (a) $\rho=1,0 \%$ ir (b) $\rho=2,0 \%$

3.6 paveiksle parodytos momentų ir kreivių diagramos, imant pastovų armatūros tamprumo moduli $\left(E_{s}=210 \mathrm{GPa}\right)$ bei efektyvuji skerspjūvio aukštị $(d=0,37 \mathrm{~m})$. Iš gautų rezultatų matyti, kad betono klasè turi didelę itaką lenkiamuju gelžbetoninių elementų deformacijoms. Silpnai ir vidutiniškai armuotuose elementuose ( $\rho \leq 1,0 \%$ ) betono klasei mažejant nuo $C 60 / 75$ iki $C 20 / 25$ atitinkamai mažeja pleišèjimo momentas $41 \%$. Stipriai armuotuose elementuose ( $\rho=2,0 \%$ ) betono klasei kintant nuo $C 60 / 75$ iki $C 20 / 25$ pleišèjimo momentas mažèja $29 \%$.
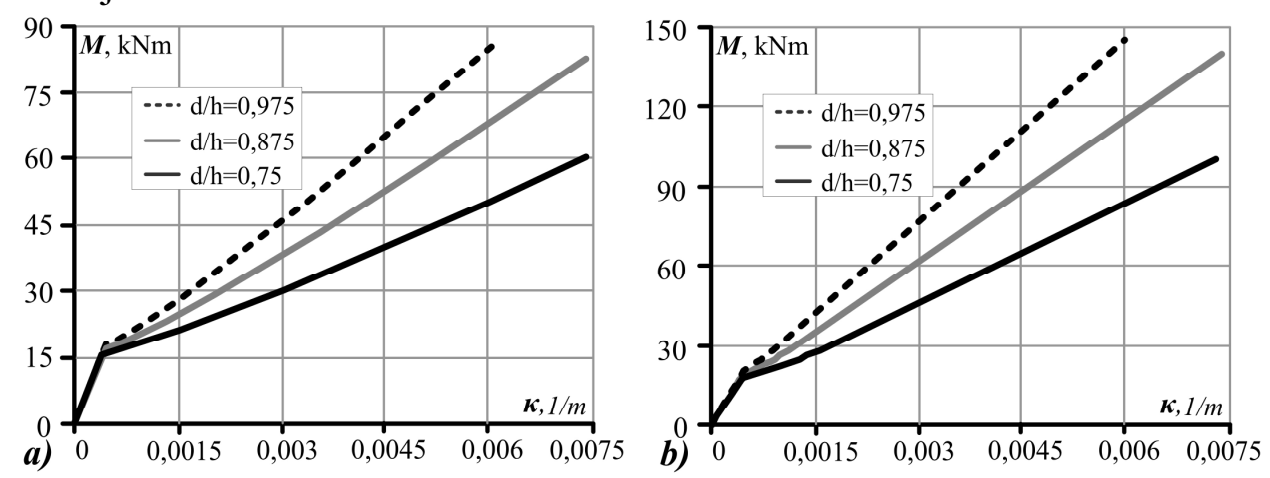

3.7 pav. Momentų-kreivių diagramos kintant naudingam skerspjūvio aukščiui. Armavimo koeficientai: (a) $\rho=1,0 \%$ ir (b) $\rho=2,0 \%$

Fig. 3.7. Moment-curvature diagrams for ranging normalised effective depth. Reinforcement ratio: (a) $\rho=1,0 \%$ ir (b) $\rho=2,0 \%$ 
Atlikta analizè lenkiamiesiems gelžbetoniniams elementams kintant armavimo koeficientui, imant vienodą betono klasę $(C 20 / 25)$ bei pastovų armatūros tamprumo moduli ( $\left.E_{s}=210 \mathrm{GPa}\right)$. Iš gautujų momentų-kreivių diagramų (3.7 pav.), galima teigti, kad efektyvus skerspjūvio aukštis turi itakos lenkiamų gelžbetoninių elementų kreiviams, bet neturi įtakos pleišejimo apkrovai.
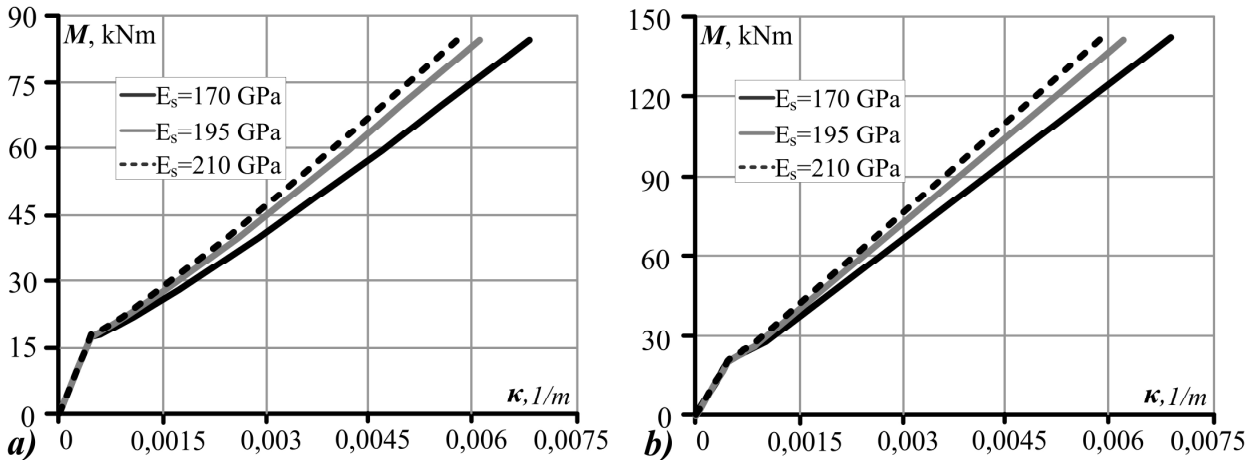

3.8 pav. Momentų-kreivių diagramos kintant armatūros tamprumo moduliui. Armavimo koeficientai: (a) $\rho=1,0 \%$ ir (b) $\rho=2,0 \%$

Fig. 3.8. Moment-curvature diagrams for ranging elastic modulus of reiforcement. Reinforcement ratio: (a) $\rho=1,0 \%$ ir (b) $\rho=2,0 \%$

3.8 paveiksle parodytos momentų ir kreivių diagramos, imant vienodą betono klasę $(C 20 / 25)$ bei efektyvu skerspjūvio aukšti $(d=0,37 \mathrm{~m})$. Kaip matyti, didejjant armatūros tamprumo moduliui lenkiamojo gelžbetoninio elemento kreiviai mažèja. Armatūros tamprumo modulis praktiškai neturi įtakos pleišejimo momentui.

2 žingsnis. Taikant sluoksnių metodą, aprašytą 3.3 poskyryje, apskaičiuojama tempiamojo betono vidutinių itempių ir vidutinių deformacijų kreive kiekvienai momentų-kreivių diagramai generuotai pirmajame žingsnyje. Atliekama parametrų turinčių i̇takos tempiamajam sustandèjimui analizè. Vidutinių įtempių ir vidutinių deformacijų diagramos, išreikštos santykiniais $\sigma / f_{c t}$ ir $\varepsilon / \varepsilon_{c r}$ dydžiais pateiktos 3.9-3.11 paveiksluose. 

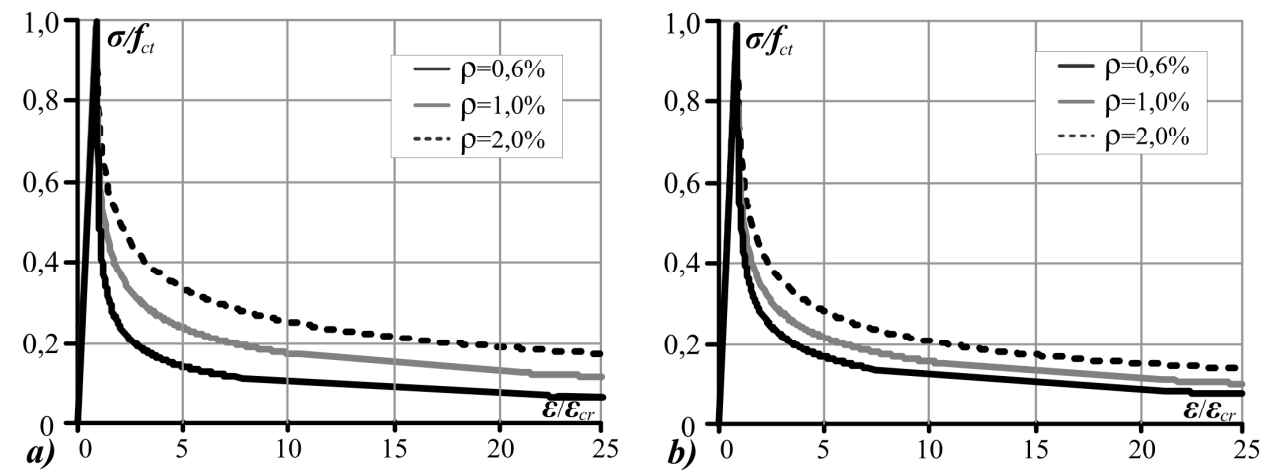

3.9 pav. Skaitiškai nustatytos tempimo sustandejjimo diagramos kintant armavimo koeficientui. Betono klasès: (a) $C 20 / 25$ ir (b) $C 60 / 75$

Fig. 3.9. Numerically derived tension stiffening diagrams for varying reinforcement ratio. Grades of concrete: (a) C20/25 and (b) C60/75

Kaip matyti iš 3.9 paveikslo, stipriai armuotų elementų ( $\rho=2,0 \%)$ tempiamasis sustandejjimas yra ženkliai mažesnis lyginant su mažai ir vidutiniškai armuotais elementais ( $\rho \leq 1,0 \%$ ). Čia buvo imtas vienodas armatūros tamprumo modulis $\left(E_{s}=210 \mathrm{GPa}\right)$ bei efektyvusis skerspjūvio aukštis $(d=0,37 \mathrm{~m})$.
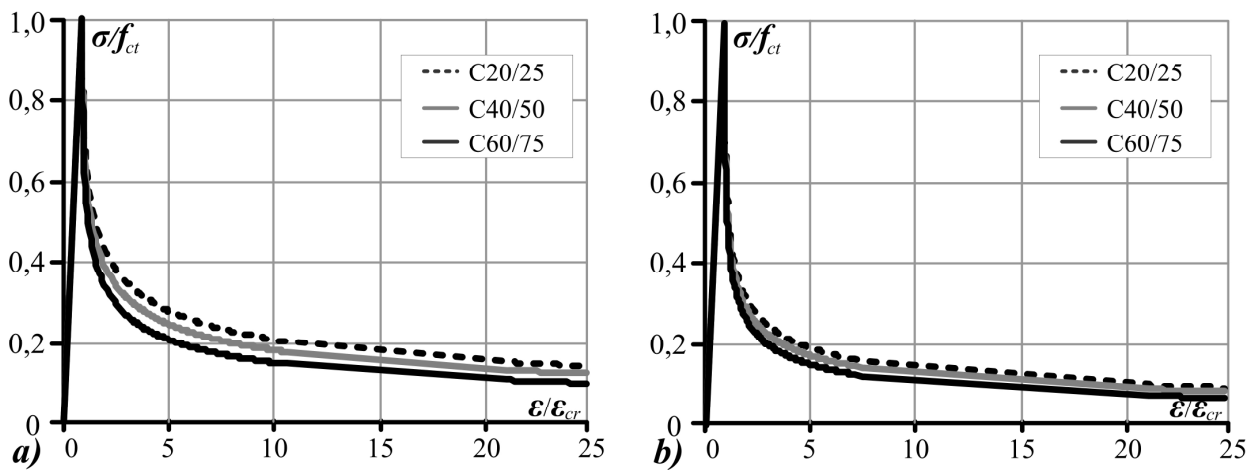

3.10 pav. Skaitiškai nustatytos tempimo sustandejjimo diagramos kintant betono klasei. Armavimo koeficientai: (a) $\rho=1,0 \%$ ir (b) $\rho=2,0 \%$

Fig. 3.10. Numerically derived tension stiffening diagrams for varying grade of concrete. Reinforcement ratio: (a) $\rho=1,0 \%$ ir (b) $\rho=2,0 \%$

3.10 paveiksle parodytos tempiamojo betono vidutinių itempių ir vidutinių deformacijų diagramos, kintant betono klasei. Kaip matyti, šios diagramos išreikštos santykiniais itempiais $\sigma / f_{c t}$ praktiškai sutapo. Analizès metu nustaty- 
ta, kad didejant betono stipriui tempiant dideja tempimo ittempiai betone. Čia buvo imti pastovūs armatūros tamprumo modulis $\left(E_{s}=210 \mathrm{GPa}\right)$ bei efektyvus skerspjūvio aukštis $(d=0,37 \mathrm{~m})$.
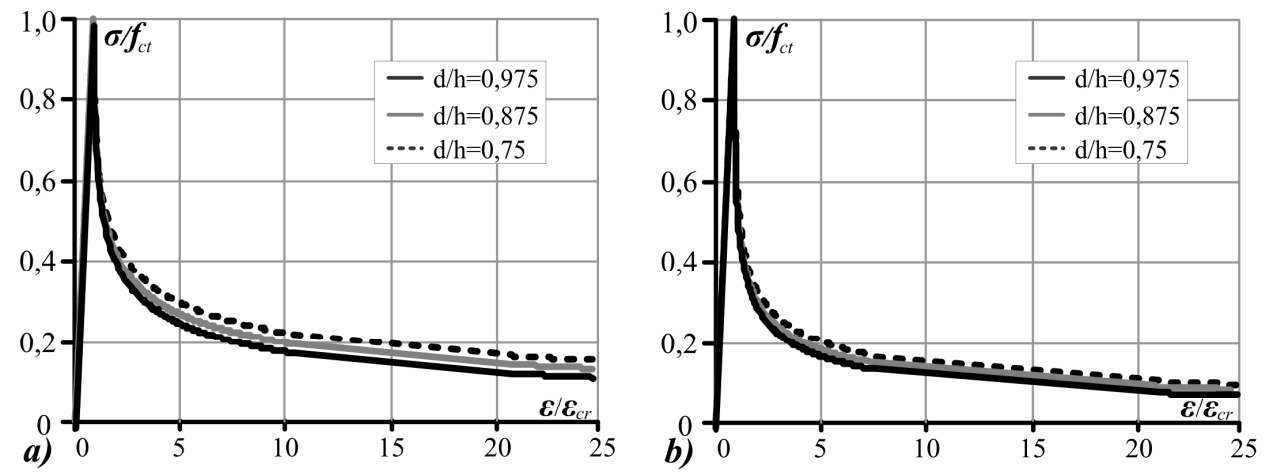

3.11 pav. Skaitiškai nustatytos tempimo sustandèjimo diagramos kintant naudingam skerspjūvio aukščiui. Armavimo koeficientai: (a) $\rho=1,0 \%$ ir (b) $\rho=2,0 \%$

Fig. 3.11. Numerically derived tension stiffening diagrams for varying normalised effective depth. Armavimo koeficientai: (a) $\rho=1,0 \%$ ir (b) $\rho=2,0 \%$

3.11 paveiksle parodytos tempiamojo betono vidutinių itempių ir vidutinių deformacijų diagramos, kintant efektyviajam skerspjūvio aukščiui. Nustatyta, kad efektyviojo skerspjūvio aukščio itaka tempiamojo sustandejjimo diagramos formai nedidele.
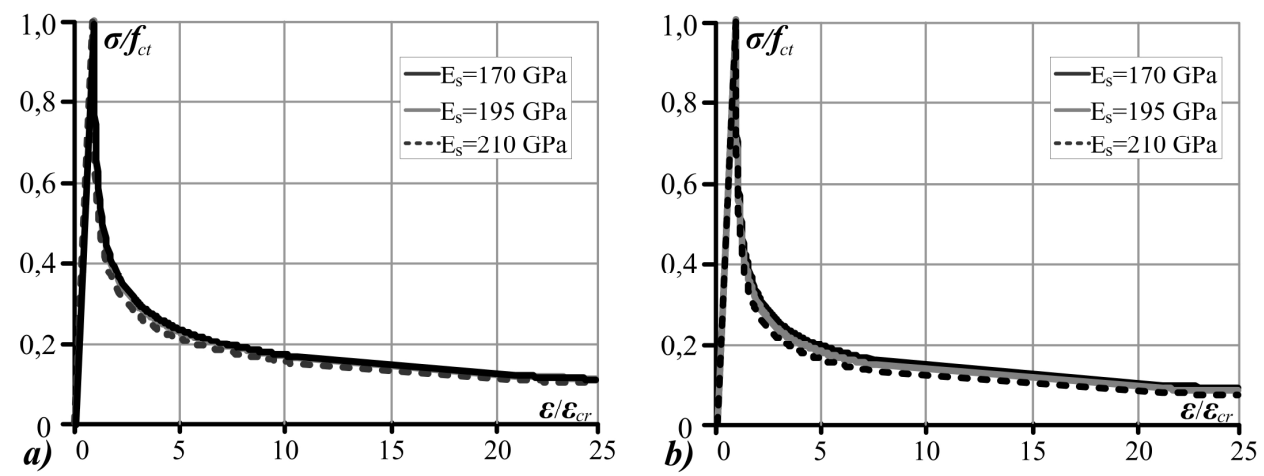

3.12 pav. Skaitiškai nustatytos tempimo sustandejjimo diagramos kintant armatūros tamprumo moduliui. Armavimo koeficientai: (a) $\rho=1,0 \%$ ir (b) $\rho=2,0 \%$

Fig. 3.12. Numerically derived tension stiffening diagrams for varying elastic modulus of reiforcement. Reinforcement ratio: (a) $\rho=1,0 \%$ ir (b) $\rho=2,0 \%$ 
3.12 paveiksle parodytos tempiamojo betono vidutinių itempių ir vidutinių deformacijų diagramos esant skirtingiems armatūros tamprumo moduliams. Kaip matyti armatūros tamprumo modulio itaka tempiamojo sustandejjimo diagramos formai nedidelè.

\subsection{Tempiamojo sustandèjimo modelis}

Atlikus regresinę analizę, nustatyta, kad didžiausią itaką tempiamajam sustandejjimui turi armavimo koeficientas bei armatūros ir betono tamprumo moduliai. Pasiūlytame modelyje buvo priimtas vienas nepriklausomas kintamasis armavimo koeficiento ir armatūros ir betono tamprumo moduliu santykio sandauga ( $\rho n)$. Tempiamajam sustandejjimui aprašyti, pasiūlyta tokia formulè:

$$
\sigma_{t}=\frac{f_{c t}}{1+A\left(\frac{\varepsilon}{\varepsilon_{c r}}-1\right)^{0,5}},
$$

čia A - koeficientas, kuris apskaičiuojamas pagal formulę:

$$
A=0,76+0,165 \rho n,
$$

čia nustatytas $\rho n$ parametro koreliacijos koeficientas lygus 0,921 , o pasiūlytojo modelio determinacijos koeficientas $-r^{2}=0,943$.

3.13a paveiksle punktyrine linija pavaizduotos tempiamojo sustandejimo diagramos, gautos taikant pasiūlytą modeli (3.24). Kartu 3.13a paveiksle ištisine linija parodytos tempiamojo sustandejjimo kreivès gautos iš skaitinio eksperimento momentų-kreivių diagramų. Taikant pagal pasiūlytą modelị gautas tempiamojo sustandejjimo kreives buvo apskaičiuotos momentų-kreivių diagramos, kurios parodytos punktyrine linija $3.13 \mathrm{~b}$ paveikslas. Kartu $3.13 \mathrm{~b}$ paveiksle ištisine linija atidètos momentų-kreivių diagramos apskaičiuotos pagal EC2. Kaip matyti, gautas geras EC2 ir pasiūlyto modelio (3.24) skaičiavimo rezultatų sutapimas. 

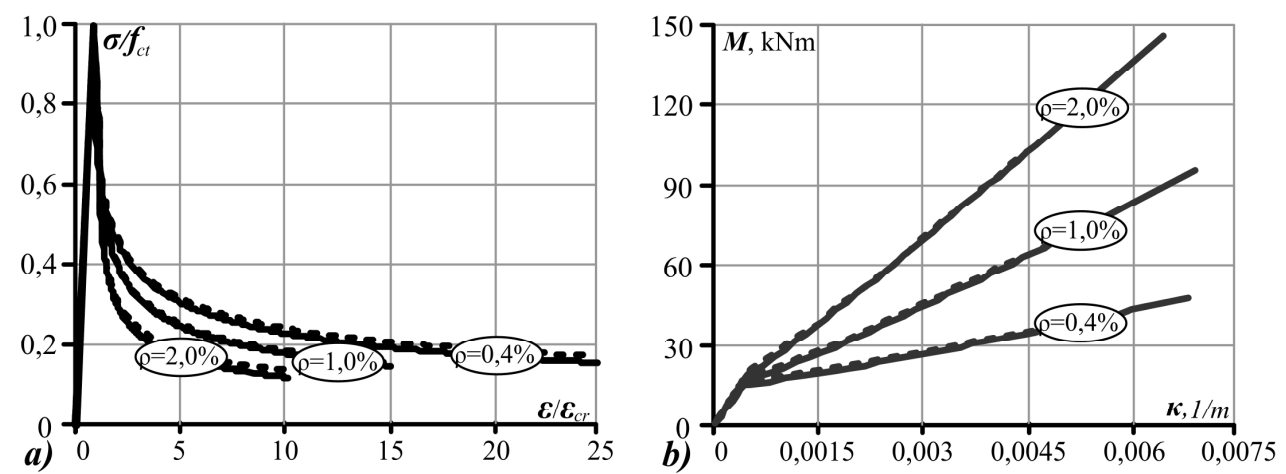

3.13 pav. (a) tempiamojo sustandèjimo kreivès; (b) apskaičiuotos momentų-kreiviu diagramos

Fig. 3.13. (a) tension stiffening curves; (b) calculated moment-curvature diagrams

\subsection{Nesudėtingas lenkiamujų gelžbetoninių elementų kreivių skaičiavimo metodas}

Šiame poskyryje pateikiamas autoriaus pasiūlytas nesudetingas lenkiamujjų gelžbetoninių elementų kreivių skaičiavimo metodas. Kaip parodyta 3.14 paveiksle, momentų-kreivių diagrama sudalinama i dvi tiesines dalis. Tamprioje stadijoje kreiviai apskaičiuojami pagal žinomą formulę:

$$
\kappa_{e l}=\frac{M}{E_{c} I_{e l}},
$$

čia $I_{e l}$ - nesupleišèjusiojo lenkiamojo gelžbetoninio elemento inercijos momentas; $E_{c}$ - betono tamprumo modulis.

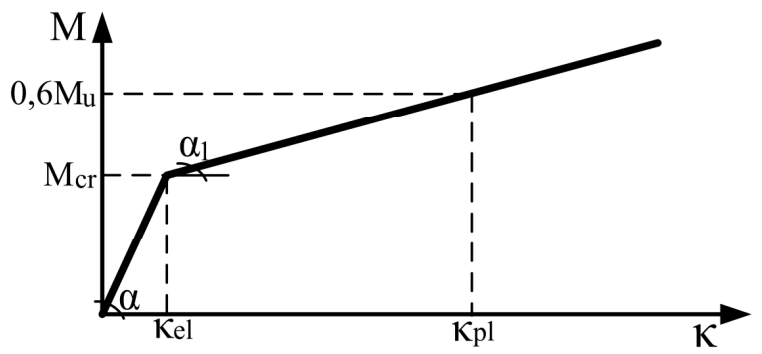

3.14 pav. Lenkiamo gelžbetoninio elemento momentų-kreivių diagrama

Fig. 3.14. Moment-curvature diagram for RC element in bending 
Supleišejusio lenkiamojo gelžbetoninio elemento kreiviai nustatomi taip:

$$
\kappa=\frac{M_{c r}}{E_{c} I_{e l}}+\frac{M-M_{c r}}{E_{c} I_{e l} \gamma} .
$$

Koeficientas $\gamma$ nustatomas, remiantis EC2 kreivių skaičiavimo metodu $0,6 M_{u}$ apkrovos intensyvumo lygyje ir apskaičiuojamas taip:

$$
\gamma=\frac{\operatorname{tg} \alpha_{1}}{\operatorname{tg} \alpha} \text { arba } \gamma=\frac{I_{e f}}{I_{e l}},
$$

čia

$$
\begin{gathered}
\operatorname{tg} \alpha=E_{c} I_{e l}, \\
\operatorname{tg} \alpha_{1}=E_{c} I_{e f} .
\end{gathered}
$$

Remiantis skaitinio eksperimento metu gautosiomis momentų-kreivių diagramomis, esant $0,6 M_{u}$ apkrovos intensyvumo lygiui, buvo atlikta regresinè analizè koeficientui $\gamma$ nustatyti:

$$
\gamma=-0,033-0,354 d / h-0,092 \ln \left(\frac{\rho n}{d / h}\right)+0,436 d / h(\rho n)^{0,4} .
$$

Apskaičiuoti elementų, turinčių skirtingus armavimo koeficientus, $\rho$, kreiviai, atitinkantys $0,6 M_{u}$ apkrovos intensyvumo lygi, taikant pasiūlytaji bei EC2 metodus, pateikti 3.15 paveiksle. Gautieji rezultatai išreikšti santykiniais dydžiais $\kappa_{\text {calc }} / \kappa_{\text {obs }}$.

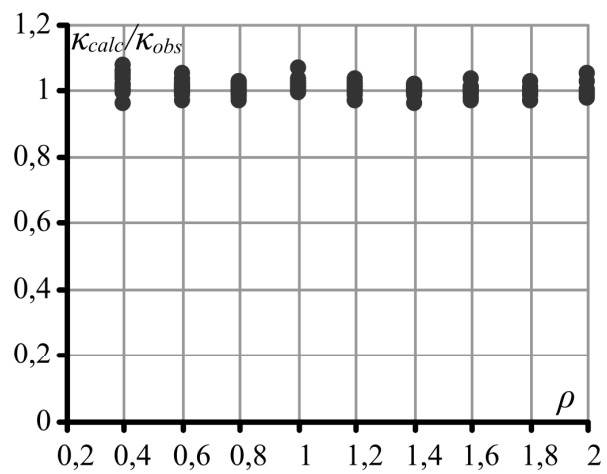

3.15 pav. $\kappa_{\text {cald }} / \kappa_{o b s}$ kintant armavimo koeficientui

Fig. 3.15. $\kappa_{c a l d} / \kappa_{o b s}$ for varying reinforcement ratio 
Kaip matyti iš pateiktojo 3.15 paveikslo, pasiūlytas lenkiamuju gelžbetoninių elementų kreivių skaičiavimo metodas (3.31) gerai atitinka EC2 metodo skaičiavimo rezultatus.

\subsection{Trečiojo skyriaus rezultatai ir išvados}

1. Atlikta tempiamojo sustandejjimo modelio lenkiamiesiems elementams parametrinè analizè. Nustatyta, kad šis efektas priklauso nuo tempiamojo betono stiprio, armavimo koeficiento bei armatūros ir betono tamprumo modulių santykio.

2. Pasiūlytasis lenkiamujų elementų tempiamojo sustandejjimo modelis gerai atitinka Euronormų nuostatas, nustatytos iki $1 \%$ kreivių skaičiavimo paklaidos.

3. Nustatyta, kad tempiamojo sustandèjimo diagramos gautos iš tempiamujų ir lenkiamuju gelžbetoninių elementų yra skirtingos. Tempiamojo sustadejimo efektas yra didesnis tempiamuose elementuose lyginant su lenkiamaisiais. 


\section{Skaitiniai ir palyginamieji skaičiavi- mai taikant pasiūlytuosius medžiagu modelius}

Šiame skyriuje statistiškai nagrinejjamas pasiūlytujjų betono tempiamojo sustandejjimo diagramų, gautų iš tempiamujų ir lenkiamujų gelžbetoninių elementų, tikslumas. Skyrių sudaro dvi dalys. Pirmojoje dalyje atlikta tempiamiesiems elementams gautos tempiamojo sustandejimo diagramos adekvatumas, analizès rezultatus palyginant su literatūroje paskelbtų eksperimentinių tyrimų rezultatais. Palyginime panaudoti 7 autoriu grupių tyrimo duomenys bei 4 skaičiavimo metodikos. Antrojoje skyriaus dalyje atlikta lenkiamujų gelžbetoninių elementų metodų tikslumo analizè. Be pasiūlytojo modelio buvo analizuoti normų metodai ir kiti tempiamojo sustandejjimo modeliai (viso 6 modeliai). Tuo tikslu panaudoti Gribniak (2009) surinkti 6 autorių grupių eksperimentiniai duomenys. 


\subsection{Tempiamujų gelžbetoninių elementų eksperimentinių ir teorinių deformacijų palyginimas}

Poskyryje pateikiami kitų autorių gauti centriškai tempiamujju gelžbetoninių elementų eksperimentų duomenys ir palyginami su skaičiavimo rezultatais pagal ivairius metodus ir modelius.

\subsubsection{Eksperimentiniai duomenys}

Darbe panaudoti 7 tyrimo grupių išbandytu trumpalaike apkrova eksperimentiniai duomenys (viso 35 gelžbetoniniai elementai). Visi tempiamieji gelžbetoniniai elementai buvo kvadratinio arba stačiakampio skerspjūvio, bet turëjo skirtingą ilgi $l$ bei atstumą $l_{0}$, kuriame buvo išmatuotos deformacijos. Pagrindinès eksperimentinių bandinių charakteristikos pateiktos 4.1 lentelèje, o skaičiuojamoji schema 4.1 paveiksle.

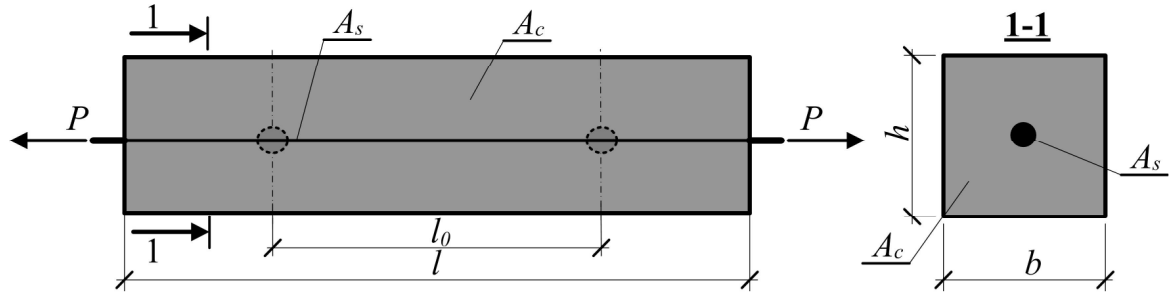

4.1 pav. Centriškai tempiamojo gelžbetoninio elemento skaičiuojamoji schema

Fig. 4.1. Uniaxial tension RC element calculation scheme

Fields ir Bishoff (2004), Bischoff ir MacLaggan (2006), Gilbert ir Wu (2008), Al-Fayadh (1997), Fischer ir Li (2002), Ouyang et al. (1997) išbandyti tempiamieji gelžbetoniniai elementai buvo vidutiniškai $(\rho \leq 1,5 \%)$ arba stipriai ( $\rho>1,5 \%$ ) armuoti. Abrisami ir Mitchel (1996) eksperimentiniai bandiniai buvo vidutiniškai armuoti. Gelžbetoniniai elementai buvo armuoti vienu arba keliais armatūros strypais, jų skaičius $n$ bei armatūros skersmuo $\phi_{s}$ pateikti 4.1 lentelëje. Eksperimentiniai bandiniai betonuoti iš vidutinio stiprio bei stipraus betono $f_{c m}=34,9-132,55 \mathrm{MPa}$ ir kietejo ivvairiomis sąlygomis. Kai kurie elementai buvo laikomi drègnoje aplinkoje, todèl juose nepasireiškè betono traukimasis. 4.1 lentelejje pateikta elementų laisvojo betono traukimosi deformacija $\varepsilon_{s h 0}$. 
4.1 lentelè. Pagrindinės eksperimentinių tempiamujų gelžbetoninių elementų charakteristikos

Table 4.1. Main characteristics of experimental unaxial tension RC elements

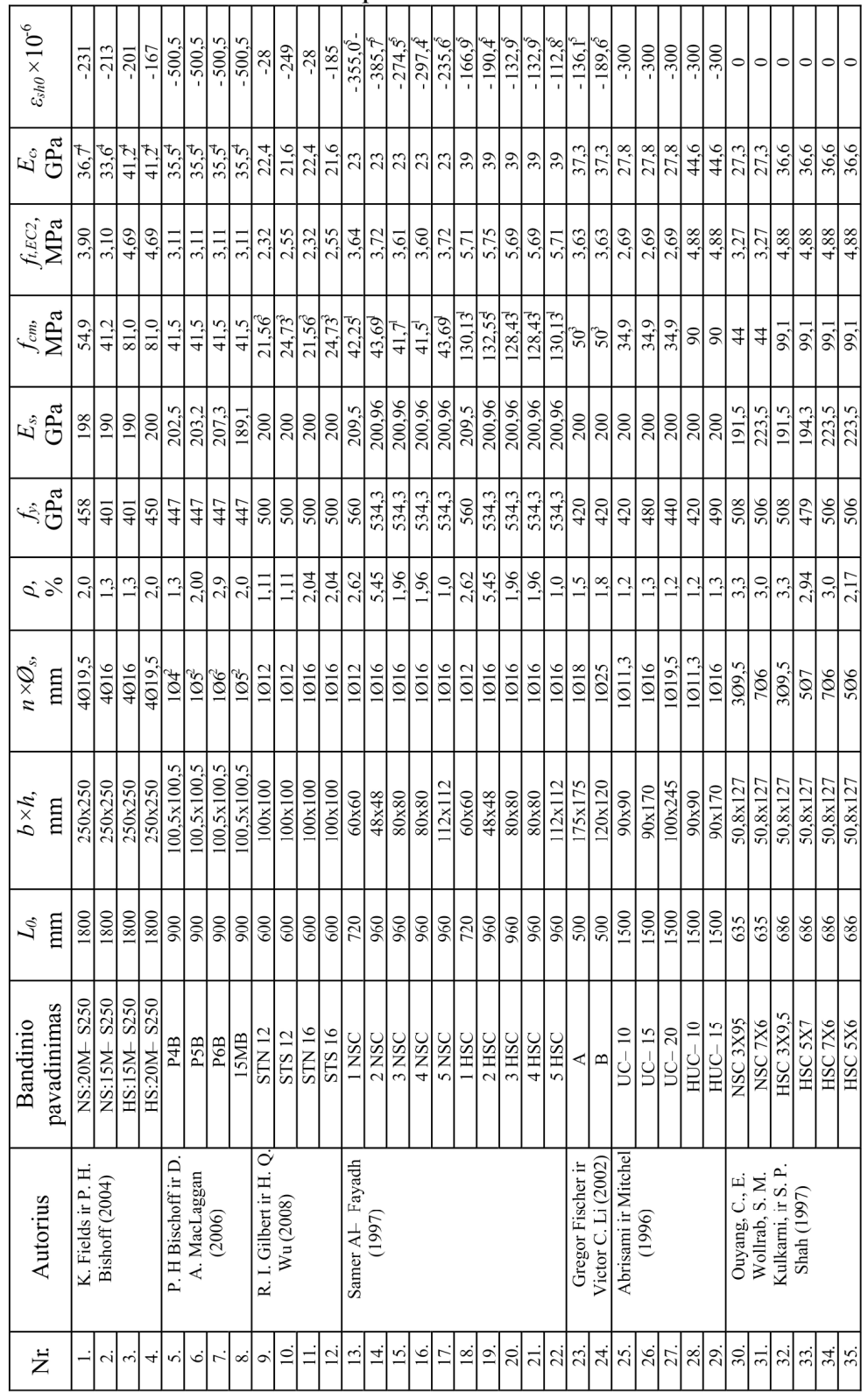

${ }^{1}$ - betono $f_{c m}$ apskaičiuotas pagal eksperimentiškai nustatytaji betono kubelini $\left(f_{c 15}\right)$ stiprị; ${ }^{2}-$ lygūs armatūros strypai; ${ }^{3}$ - eksperimentiškai nustatytas betono kubelinis $f_{c m}$ stipris; ${ }^{4}$ - betono tamprumo modulis $E_{c}$ apskaičiuotas pagal EC2 skaičiavimo metodika, kai santykinis oro drègnis $R H=70 \%$. 
4.2 paveiksle pateikti Gilbert ir Wu (2008) keturių tempiamuju gelžbetoninių elementų eksperimentinès apkrovos ir deformacijų diagramos. 4.2a paveiksle parodyti STN12 ir STS12 bandinių (4.1 lentelè, Nr. 9 ir 10) eksperimentiniai rezultatai. Bandinys 9 buvo laikytas drègnoje aplinkoje $(\mathrm{RH}=100 \%)$, todèl jame nepasireiškè betono traukimasis. Dèl betono traukimosi elementas STS12 pradèjo anksčiau pleišèti, todèl turejo didesnes deformacijas. Analogiški rezultatai gauti bandiniams STN16 ir STS16 (Nr. 11 ir 12). Kitu statistineje analizèje panaudotų elementų eksperimentinès apkrovos ir deformacijos diagramos pateiktos priede A.
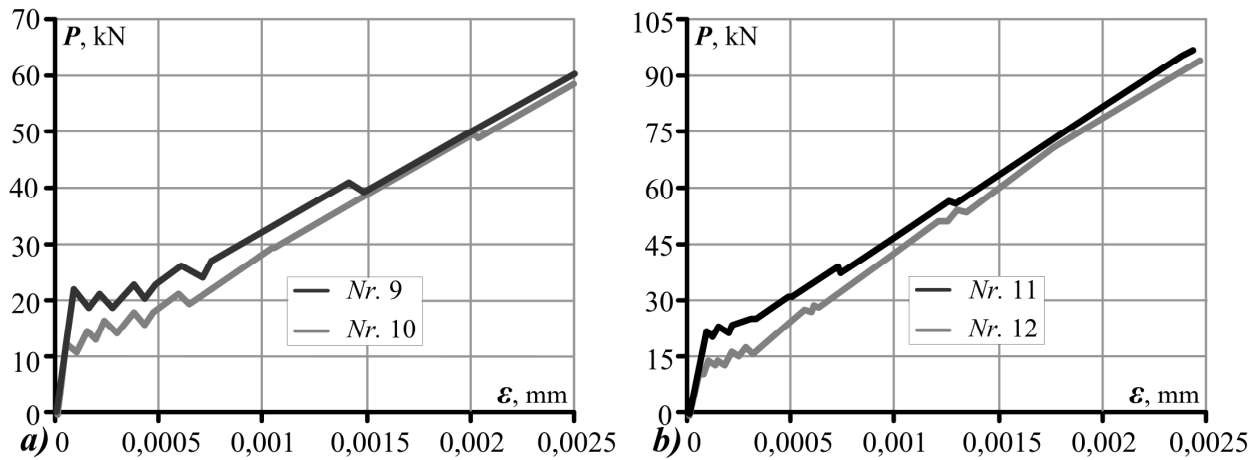

4.2 pav. Centriškai tempiamujų gelžbetoninių elementų eksperimentų apkrovosdeformacijų diagramos

Fig. 4.2. Unaxial tension RC elements experimental stress-strain diagrams

\subsubsection{Tempiamojo betono itempių ir deformacijų diagramų gavimas iš eksperimentinių duomenų}

Taikant eksperimentines tempiamujų gelžbetoninių elementų apkrovos ir deformacijų kreives, pateiktas 4.1.1 skirsnyje ir priede A, bei formules, aprašytas 2.2 poskyryje, gautos betono tempiamojo sustandejjimo diagramos. $4.2 \mathrm{a}$ paveiksle parodytos apskaičiuotos STN12 ir STS12 bandinių (4.1 lentelè, Nr. 9 ir 10) tempimo sustandejjimo diagramos. Jos pavaizduotos taikant santykinius $\sigma / f_{c t}$ ir $\varepsilon / \varepsilon_{c r}$ dydžius. Kaip minèta, bandiniai 9 ir 11 buvo laikyti drègnoje aplinkoje $(\mathrm{RH}=100 \%)$, todèl juose nepasireiške betono traukimasis. Kita vertus, elementuose STS12 ir STS16 dèl traukimosi betone atsirado tempimo itempiai, todèl jie pradèjo anksčiau pleišèti. $4.2 \mathrm{~b}$ paveiksle pateiktos apskaičiuotos vidutinių itempių ir vidutinių deformacijų diagramos bandiniams STN16 ir STS16 (Nr. 11 ir 12). Kitiems elementams gautos diagramos pateiktos priede A. 

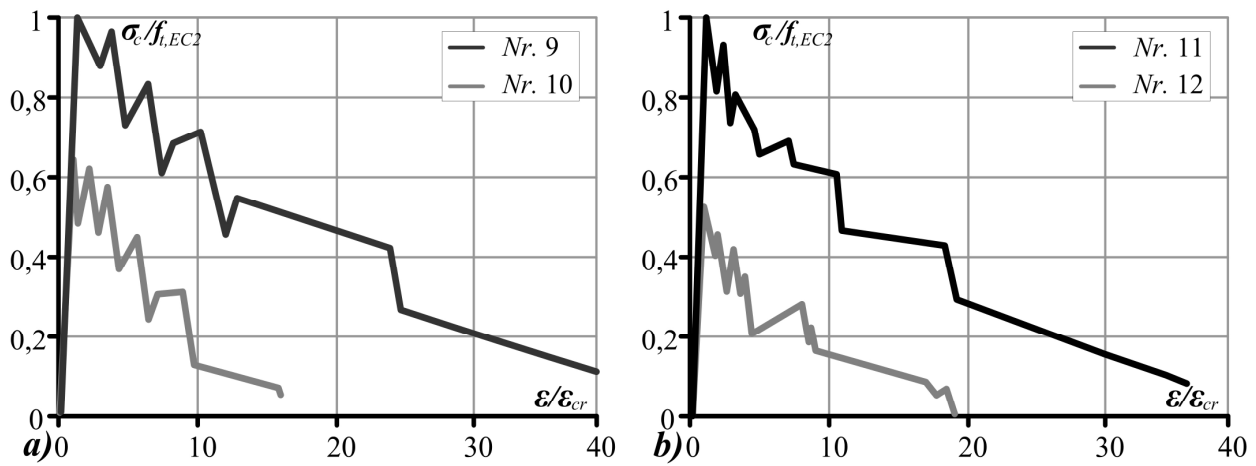

4.3 pav. Eksperimentinių centriškai tempiamujų gelžbetoninių elementų tempiamojo betono vidutinių itempių ir vidutinių deformacijų diagramos

Fig. 4.3. Experimental unaxial tension RC members computed tension-stiffening relationship for concrete in tension

Kaip matyti iš 4.3 paveikslo, betono traukimasis gali turèti nemažą itaką tempiamojo sustandejjimo diagramų formai. Betono traukimasis sukelia papildomų įtempių armatūroje (gniuždymo) ir betone (tempimo). Dèl šios priežasties gali ženkliai sumažèti tempiamojo gelžbetoninio elemento atsparumas pleišèjimui bei padidèti tokio elemento deformacijos.

Betono traukimosi itaką trumpalaike apkrova apkrautų gelžbetoninių elementu deformacijoms tyrinejo Bischoff (1983), Foster et al. (1996), Gilbert (1999, 2001), Kaklauskas ir Gribniak (2005), Gribniak ir kt. (2008), Kaklauskas et al. (2009), Sato et al. (2007), Bischoff ir Johnson (2007). Centriškai tempiamojo gelžbetoninio elemento betono traukimosi deformacija apskaičiuojama taip:

$$
\varepsilon_{c, s h}(t, \tau)=\frac{P+N_{s h}(t, \tau)}{E_{c, e f f}(t, \tau) A_{c}+E_{s} A_{s}}=\frac{P+\varepsilon_{s h}(t, \tau) E_{c, e f f}(t, \tau) A_{c}}{E_{c, e f f}(t, \tau) A_{c}+E_{s} A_{s}},
$$

čia $P$ - išorinè apkrova; $A_{c}$ ir $A_{s}$ - atitinkamai gelžbetoninio elemento betono bei armatūros skerspjūvio plotai; $\varepsilon_{s h}$ - betono traukimosi deformacija; $E_{s}-$ armatūros tamprumo modulis; $E_{c, e f f}$ - efektyvusis betono tamprumo modulis.

Efektyvusis betono tamprumo modulis nustatomas taip:

$$
E_{c, e f f}(t, \tau)=\frac{E_{c}(\tau)}{1+\varphi(t, \tau)},
$$

čia $E_{c}$ - betono tamprumo modulis; $\varphi$ - valkšnumo koeficientas.

Dèl traukimosi atsiradę įtempiai betone nustatomi pagal formulę: 


$$
\sigma_{c, s h}(t, \tau)=-\frac{\varepsilon_{s h}(t, \tau) E_{s} \rho}{1+E_{s} \rho / E_{c, e f f}(t, \tau)}
$$

čia $\alpha=A_{s} / A_{c}-$ armavimo koeficientas.

Iš apkrovos ir deformacijų diagramų gautos tempimo sustandèjimo kreivès perskaičiuojamos, taikant (4.1) ir (4.3). Elementams STS12 ir STS16 perskaičiuotos tempiamojo sustandejjimo kreivès parodytos 4.4 paveiksle kartu su nesitraukusių elementu STN12 ir STN16 kreivemis. Kaip matyti, eliminavus susitraukima, susitraukusiems ir nesusitraukusiems elementams gautosios diagramos praktiškai sutapo.
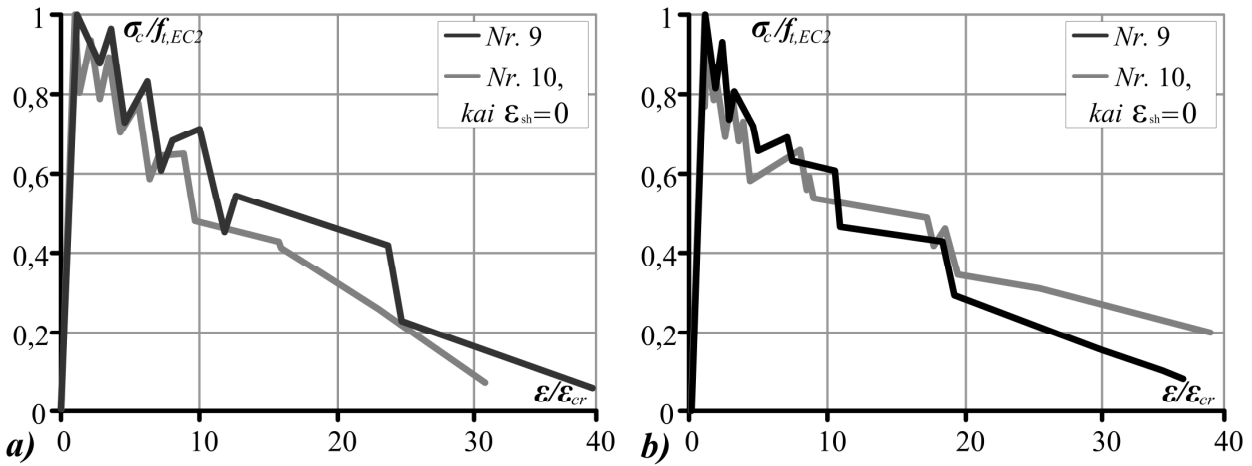

4.4 pav. Tempimo sustandejimo diagramos, eliminavus betono susitraukimą

Fig. 4.4. Tension-stiffening diagrams taking into consideration shrinkage effect

\subsubsection{Gautosios ir kitų autorių pasiūlytų tempiamojo betono itempių ir deformacijų diagramų palyginimas}

Šiame skirsnyje atlikta dviejų dalių statistinè lyginamoji analizè. Pirmojoje dalyje eksperimentinès apkrovos ir deformacijų diagramos, aprašytos 4.1.1 skirsnyje, palygintos su skaičiavimo rezultatais pagal pasiūlytaji modeli. Reikia pažymèti, kad ši analizè buvo atlikta dvejopai: 1) nevertinant betono traukimosi ir 2) ji eliminavus. Antrojoje lyginamosios statistikos dalyje eksperimentiniai duomenys palyginti su skaičiavimo rezultatais gautais iš kitų fizinių modelių bei normų metodų:

1. CEB-FIP (1990) (2.5);

2. Hsu (1993) (1.12);

3. Collins ir Mitchell (1991) (1.14);

4. Fields ir Bischoff (2004) (1.20).

Eksperimentinių duomenų masyvo deformacijų taškai pagal apkrovos intensyvumą $P^{\prime}$ suskirstyti į dešimt santykinès apkrovos intervalų, kurie nustatomi taip: 


$$
P^{\prime}=\left(P-P_{c r}\right) /\left(P_{u}-P_{c r}\right), P^{\prime}=\{0,1,0,2, \ldots, 0,9,1\},
$$

čia $P_{u}$ - tempiamojo gelžbetoninio elemento laikomoji galia, imant armatūros takumo ribą $f_{y d}=400 \mathrm{MPa} ; P_{c r}$ - pleišèjimo apkrova, apskaičiuota pagal EC2.

Deformacijų skaičiavimo tikslumas buvo įvertintas santykinemis paklaido$\operatorname{mis} \Delta_{i, k}$ :

$$
\Delta_{i, k}=x_{\text {calc }} / x_{\text {obs }}, i=1,2,3, \ldots, 10, k=35,
$$

čia $x_{c a l c}$ ir $x_{o b s}$ atitinkamai - apskaičiuotos bei eksperimentiškai nustatytos tempiamuju gelžbetoninių elementų deformacijos; $i$-osios apkrovos $P^{\prime}$ lygis; $\mathrm{k}-$ eksperimentinių duomenu skaičius.

Vertinant skaičiavimo metodų tikslumą buvo nustatyti santykinės paklaidos $\Delta_{i, k}$ vidurkis $m_{\Delta}$ bei vidutinis kvadratinis nuokrypis $s_{\Delta}^{2}$ :

$$
\begin{gathered}
m_{\Delta}=\frac{1}{n} \sum_{i=1}^{n} \Delta_{i}, \\
s_{\Delta}^{2}=\frac{1}{n-1} \sum_{i=1}^{n}\left(\Delta_{i}-m_{\Delta}\right)^{2} .
\end{gathered}
$$

Deformacijų skaičiavimo adekvatumas (skaičiavimo rezultatų atitikimas eksperimentų duomenims) buvo įvertintas, taikant pasikliautinujų intervalų metodą: jeigu vienetas patenka $\mathfrak{i}$ atitinkamą pasikliautinaji intervalą, skaičiavimo metodas laikomas adekvačiu. Pasikliautinasis intervalas $1-\alpha$ tikimybei apskaičiuojamas pagal formulę:

$$
\mu_{\Delta} \in\left[m_{\Delta}-t_{1-\alpha / 2}(n-1) \times \frac{s_{\Delta}}{\sqrt{n}} ; \quad m_{\Delta}+t_{1-\alpha / 2}(n-1) \times \frac{s_{\Delta}}{\sqrt{n}}\right],
$$

čia $t(n-1)$ yra $t-$ Stjudento skirstinys, turintis $(n-1)$ laisvès laipsnių ir reikšmingumo lygmeniu $\alpha / 2 ; 1-\alpha$-patikimumo koeficientas.

Pirma, tempiamujų gelžbetoninių elementų eksperimentai palyginti su skaičiavimo rezultatais pagal pasiūlytaji modeli, neįvertinus betono traukimosi $\varepsilon_{s h}$. Antra, buvo eliminuotas betono traukimasis, perskaičiuojant eksperimentiniu duomenu apkrovos ir deformacijos diagramas pagal skirsnyje 4.1.2 pateiktą metodiką. Perskaičiuotos eksperimentinès apkrovos ir deformacijų diagramos statistiškai palygintos su modeliavimo rezultatais, kurie pateikti 4.5 ir 4.6 paveiksluose bei priede B.1 lenteleje.

Analizè parodè, kad skaičiavimo tikslumas priklauso nuo armavimo koeficiento. Todèl eksperimentiniai duomenys buvo sudalinti i dvi grupes: 


$$
\rho \leq 1,5 \% \text { ir } \rho>1,5 \% \text {. }
$$
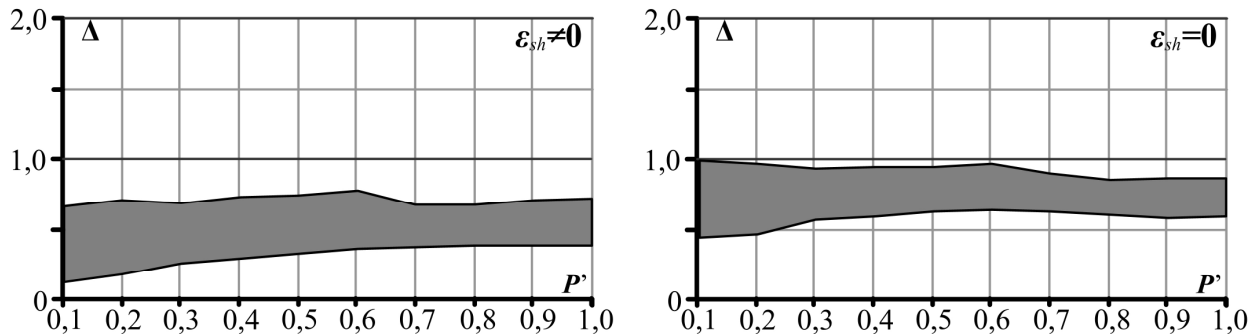

4.5 pav. Santykinès paklaidos $95 \%$ pasikliautinieji intervalai $(\rho \leq 1,5 \%)$

Fig. 4.5. Relative error $95 \%$ confidence intervals $(\rho \leq 1,5 \%)$
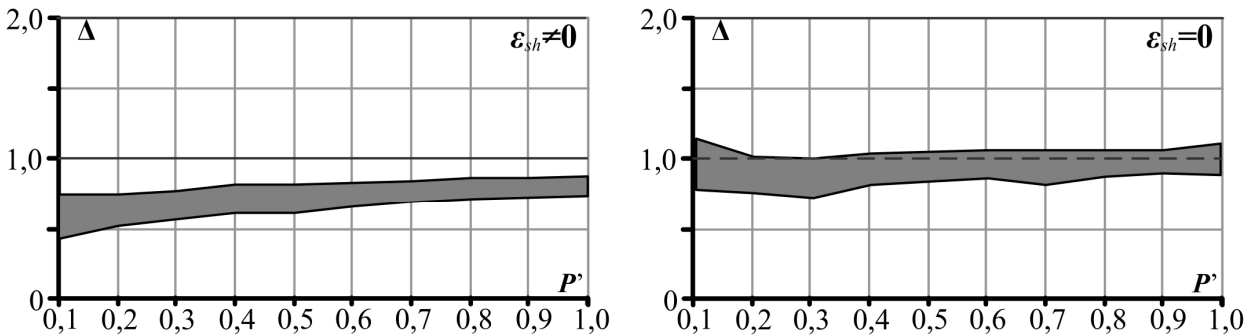

4.6 pav. Santykinès paklaidos $95 \%$ pasikliautinieji intervalai $(\rho>1,5 \%)$

Fig. 4.6. Relative error $95 \%$ confidence intervals $(\rho>1,5 \%)$

4.5 ir 4.6 paveiksluose pavaizduoti tikimybiniai intervalai charakterizuoja santykinès paklaidos variaciją (4.8), kurios kitimas priklauso nuo armavimo koeficiento $\rho$, apkrovos intensyvumo $P^{\prime}$ bei betono traukimosi $\varepsilon_{s h}$.

Apskaičiuotos tempiamuju gelžbetoninių elementų deformacijos, taikant originaliają EC2 metodiką, buvo žymiai mažesnès už eksperimentines. Nevertinant betono traukimosi, mažiau armuotiems elementams $(\rho \leq 1,5 \%)$ apkrovos lygiuose, artimuose pleišèjimo ribai, apskaičiuotos deformacijos vidutiniškai tesiekè 39,6 \% eksperimentinès reikšmès. Visuose apkrovos intervaluose santykinès paklaidos vidurkis kito nuo 0,40 iki 0,57 . Stipriau armuotiesiems elementams gautos kiek mažesnès paklaidos: $0,58-0,80$. Kai betono traukimasis buvo eliminuotas, skaičiavimas geriau atitiko eksperimento rezultatus. Mažiau armuotiems $(\rho \leq 1,5 \%)$ ir stipriau armuotiems $(\rho>1,5 \%)$ elementams santykinès paklaidos vidurkis kito ribose: atitinkamai $0,70-0,79$ ir $0,86-0,99$.

Antrojoje lyginamosios statistikos dalyje eksperimentiniai duomenys palyginti su skaičiavimo rezultatais, taikant kitus normų metodus ir fizinius modelius. 4.7 ir 4.8 paveiksluose bei priede B.2 lentelèje pateikti lyginamosios statistikos rezultatai atskirai skirtingiems armavimo koeficiento intervalams. Mažiau armuotiems elementams santykinès paklaidos vidurkis atskiriems metodams kito 
ribose: 0,64-0,70 (CEB-FIP), 0,74-1,12 (Hsu), 0,64-0,85 (Collins ir Mitchell), 0,83-0,92 (Fields ir Bischoff).
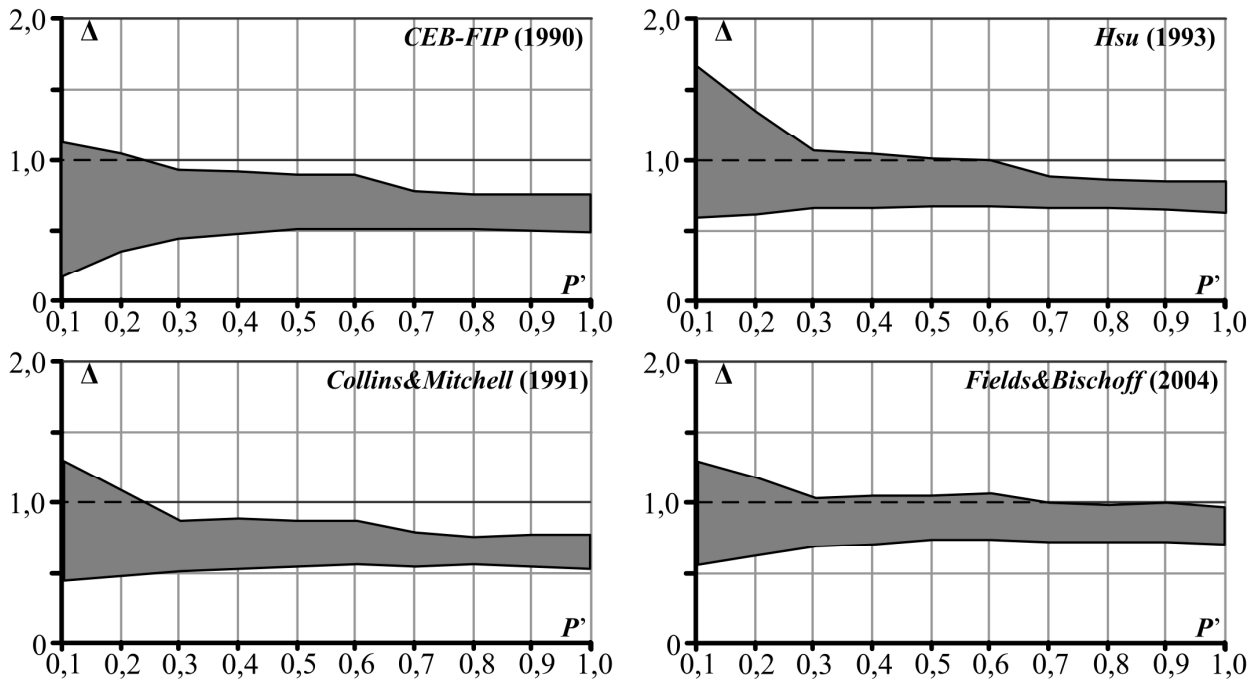

4.7 pav. Santykinès paklaidos $95 \%$ pasikliautinieji intervalai $(\rho \leq 1,5 \%)$

Fig. 4.7. Relative error $95 \%$ confidence intervals $(\rho \leq 1,5 \%)$
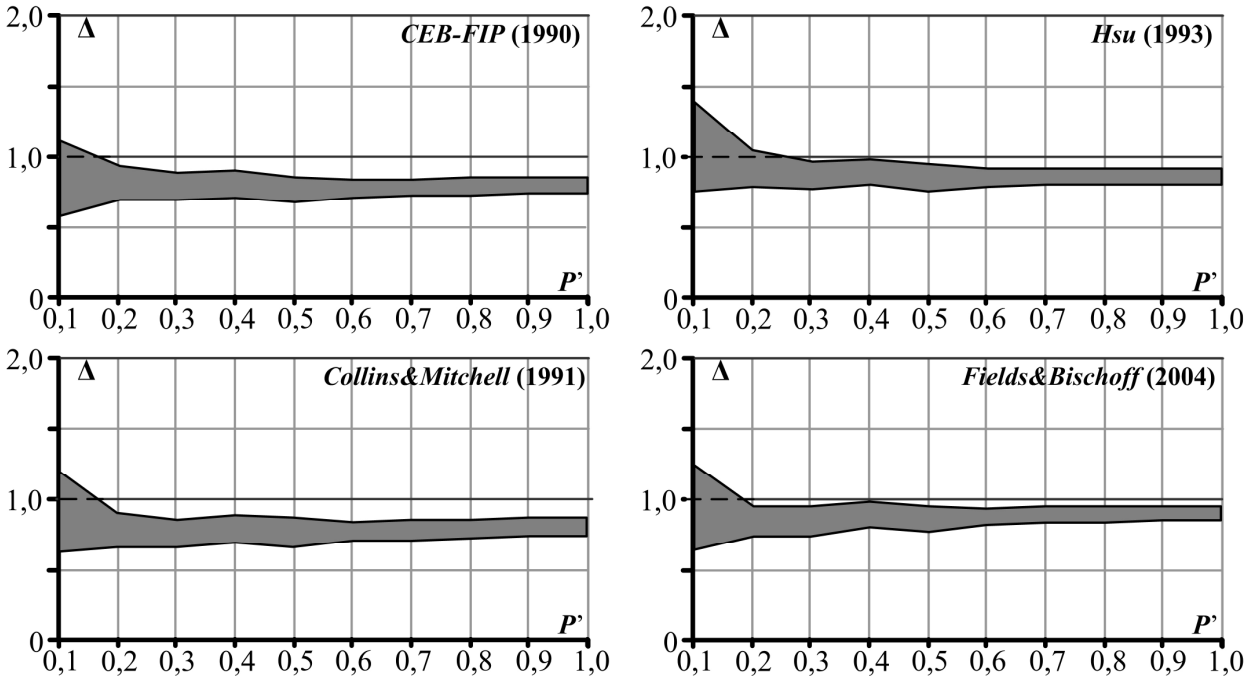

4.8 pav. Santykinès paklaidos $95 \%$ pasikliautinieji intervalai $(\rho>1,5 \%)$

Fig. 4.8. Relative error $95 \%$ confidence intervals $(\rho>1,5 \%)$

4.8 paveiksle parodytiems daugiau armuotiems elementams $(\rho>1,5 \%)$ gauti tokie rezultatai 0,77-0,85 (CEB-FIP), 0,85-1,08 (Hsu), 0,76-0,91 (Collins ir Mitchell), 0,85-0,94 (Fields ir Bischoff). Pastebetina, kad skaičiavimo rezulta- 
tų tikslumui turi armavimo koeficientas ir apkrovos intensyvumas. Analizė parodè, kad visais metodais apskaičiuotos deformacijos yra mažesnès už eksperimentines. Mažiausios paklaidos gautos, taikant Fields ir Bischoff (2004) bei Hsu (1993) modelius. Visais nagrinètais statistinès analizès atvejais gauti didžiausi variacijos koeficientai buvo $0,1-0,2 P^{\prime}$ apkrovimo lygiuose.

\subsection{Lenkiamuju gelžbetoniniu elementŭ eksperimentinių ir teorinių deformacijų palyginimas}

Poskyryje atlikta lenkiamujų gelžbetoninių elementų ilinkių skaičiavimo metodų tikslumo analizè. Pateikiami ịvairiu autorių gauti eksperimentiniai duomenys, kurie buvo palyginti su normų metodų bei fizinių modelių skaičiavimo rezultatais.

\subsubsection{Sluoksnių modelis}

Šiame darbe lenkiamujjų gelžbetoninių elementų deformacijų skaičiavime tempiamasis sustandejjimas buvo ivvertintas taikant sluoksnių metoda, kuris yra pagrịstas medžiagų atsparumo formulèmis bei pilnomis medžiagų diagramomis. 4.9 paveiksle parodytas stačiakampio gelžbetoninio elemento skerspjūvis apkrautas išoriniu lenkimo momentu. Skerspjūvis sudalinamas i horizontalius armatūros bei betono sluoksnius Kaklauskas (2001). Armatūros strypai pakeičiami ekvivalentinio skerspjūvio armatūros sluoksniu.
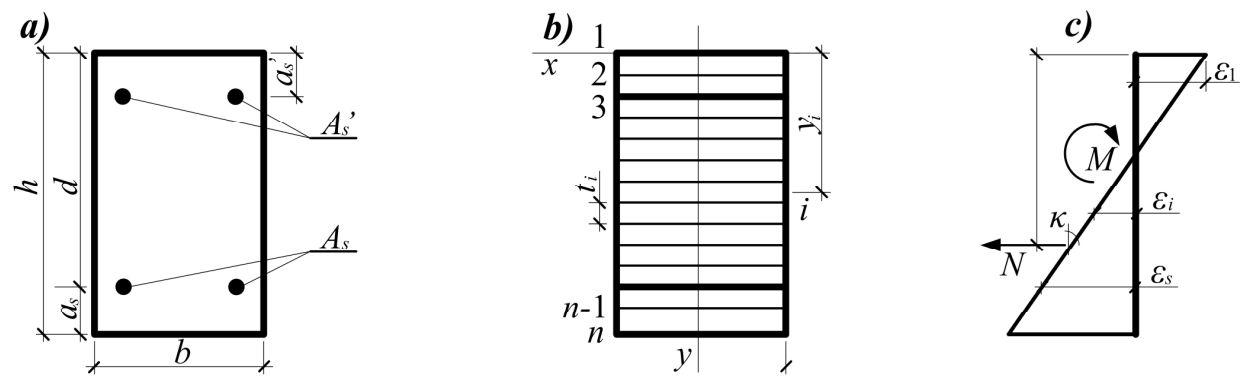

4.9 pav. Lenkiamo gelžbetoninio elemento skerspjūvis bei deformacijų diagrama

Fig. 4.9. $\mathrm{RC}$ section in bending and deformation diagram

Iteracinị lenkiamujų gelžbetonių elementų skaičiavimą galima suskirstyti i keletą žingsnių:

1. Pirmoje skaičiavimo iteracijoje visiems lenkiamo elemento sluoksniams imamos tampriosios medžiagų savybès.

2. Apskaičiuojamos redukuoto skerspjūvio charakteristikos: 
redukuoto skerspjūvio plotas apskaičiuojamas pagal formulę:

$$
A_{e}=\sum_{i=1}^{n} b_{i} t_{i} \frac{E_{i}}{E_{e}}
$$

statinis momentas $x_{1}$ ašies atžvilgiu įvertinamas taip:

$$
S_{e}=\sum_{i=1}^{n} b_{i} t_{i} y_{i} \frac{E_{i}}{E_{e}}
$$

redukuoto skerspjūvio svorio centro atstumas nuo $x_{1}$ ašies:

$$
y_{c}=\frac{S_{x 1, t r}}{A_{t r}},
$$

redukuoto skerspjūvio inercijos momentas $x$ ašies atžvilgiu:

$$
I_{x, t r}=\sum_{i=1}^{n}\left(\frac{b_{i} t_{i}^{3}}{12}+b_{i} t_{i} y^{2}\right) \frac{E_{i}}{E_{c}},
$$

čia $b_{i}$ ir $t_{i}$ - atitinkamai $i$-ojo sluoksnio plotis ir storis $(i=1,2, \ldots, n) ; y_{i}$ yra $i$ ojo sluoksnio koordinatè redukuoto skerspjūvio svorio centro ( $x$ ašies) atžvilgiu.

3. Skaičiuojamas kreivis:

$$
\kappa=\frac{M}{E_{c} I_{x, t r}} .
$$

4. Kiekviename $i$-ajame sluoksnyje apskaičiuojama deformacija:

$$
\varepsilon_{1}=\kappa y_{i} .
$$

5. Gautai $i$-ojo sluoksnio deformacijai, taikant atitinkamą medžiagos diagramą, apskaičiuojami įtempiai bei kirstinis deformacijų modulis $\overline{E_{i}}=\sigma_{i} / \varepsilon_{i}$.

6. Kiekvienam sluoksniui gauta kirstinio deformacijų modulio reikšmè $\overline{E_{i}}$ palyginama su ankstesnejje iteracijoje imta arba apskaičiuota reikšme. Jei šios reikšmès nèra lygios užduotos paklaidos (šiame darbe $\Delta=0,001 \%$ ) ribose, tai nuo 2ojo žingsnio pradedama nauja iteracija.

7. Konvergavus visų sluoksnių kirstinių deformatyvumo modulių $\overline{E_{i}}$ reikšmėms, apskaičiuojamas Moro integralas įlinkiams nustatyti. 


\subsubsection{Eksperimentinių lenkiamujų gelžbetoninių elementų analizè}

Darbe panaudoti Gribniak (2009) surinkti 6 autorių eksperimentiniai duomenys (viso 40 gelžbetoninių sijų). Visos sijos buvo stačiakampio skerspjūvio. Clark ir Speirs (1978), Ashour (2000) ir Nejadi (2005) išbandytus elementus galima charakterizuoti kaip vidutiniškai ir stipriai armuotus, tuo tarpu dauguma Figarovskij (1962), Gushcha (1968) ir Kaklauskas et al. (2005) sijų buvo silpnai armuotos. Pagrindinès eksperimentinių duomenų geometrinès bei medžiagų charakteristikos pateiktos 4.2 lenteleje. Kaip matyti, sijų armavimo koeficientas ir betono stipris kito plačiose ribose.

4.2 Lentelė Pagrindinès sijų charakteristikos

Table 4.2. Main characteristics of the beams

\begin{tabular}{|c|c|c|c|c|c|c|}
\hline Autorius & $\begin{array}{c}\text { Bandi- } \\
\text { niu } \\
\text { skaičius }\end{array}$ & $\begin{array}{c}L_{0}, \\
\mathrm{~m}\end{array}$ & $\begin{array}{c}\text { Aukštis, } \\
\mathrm{mm}\end{array}$ & $\begin{array}{c}\text { Plotis, } \\
\mathrm{mm}\end{array}$ & $\begin{array}{c}\rho, \\
\mathbf{\%}\end{array}$ & $f_{c m}, \mathrm{MPa}$ \\
\hline $\begin{array}{c}\text { Clark \&Speirs } \\
\text { (1978) }\end{array}$ & 14 & 3,20 & $200-500$ & 200 & $0,44-1,98$ & $23,0-39,6$ \\
\hline $\begin{array}{c}\text { Kaklauskas ir kt. } \\
\text { (2005) }\end{array}$ & 7 & 3,00 & 300 & 280 & 0,30 & $40,7-54,6$ \\
\hline Gushcha 1967) & 4 & 3,60 & 300 & 150 & $0,30-0,80$ & $30,9-42,0$ \\
\hline $\begin{array}{l}\text { Figarovskij } \\
\text { (1962) }\end{array}$ & 7 & 3,00 & 250 & 180 & $0,40-0,90$ & $29,4-37,1$ \\
\hline Ashour (2000) & 6 & 3,08 & 250 & 200 & $1,20-2,40$ & $60,8-98,1$ \\
\hline Nejadi (2005) & 2 & 3,50 & $333-348$ & 250 & 0,50 & 45,0 \\
\hline Viso: & $\mathbf{4 0}$ & $\mathbf{3 , 0 0 - 3 , 6 0}$ & $\mathbf{2 0 0 - 5 0 0}$ & $\mathbf{1 5 0 - 2 8 0}$ & $\mathbf{0 , 3 0 - 2 , 4 0}$ & $\mathbf{2 3 , 0 - 9 8 , 1}$ \\
\hline
\end{tabular}

\subsubsection{Gautujų ir kitụ autorių pasiūlytų tempiamojo betono itempių ir deformaciju diagramų palyginimas}

Šiame skirsnyje atlikta lenkiamuju gelžbetoninių elementų ìlinkių skaičiavimo metodų tikslumo analizè. Be pasiūlytuju modelių buvo analizuojami šie normų metodai bei tempimo sustandejjimo modeliai:

1) EC2 (CEN 2004) (3.1 poskyris);

2) SP 53-101 (1.2.3 poskyris);

3) CEB-FIP (1990) (2.5 poskyris);

4) STR 2.05.05:2005 (1.2.2 poskyris);

5) Collins ir Mitchell (1991) (1.21);

6) Fields ir Bischoff (2004) (1.28); 
7) Hsu (1993) (1.18);

8) pasiūlytasis lenkiamujų gelžbetoninių elementų tempimo sustandejjimo modelis (3.4 poskyris);

9) pasiūlytasis supaprastintas lenkiamujų gelžbetoninių elementų kreivių skaičiavimo metodas (3.5 poskyris).

Sijų įlinkiai buvo apskaičiuoti dešimtyje apkrovos lygių, t. y. $M^{\prime}=\{0,1,0,2, \ldots, 0,9,1\}$, čia $M^{\prime}$ apskaičiuojama pagal tokią formulę:

$$
M^{\prime}=\left(M-M_{c r}\right) /\left(M_{u}-M_{c r}\right),
$$

čia $M_{u}$ - lenkiamojo gelžbetoninio elemento laikomoji galia, kai armatūros takumo riba $f_{y d}=400 M P a ; M_{c r}$ - pleišèjimo momentas apskaičiuotas pagal EC2.
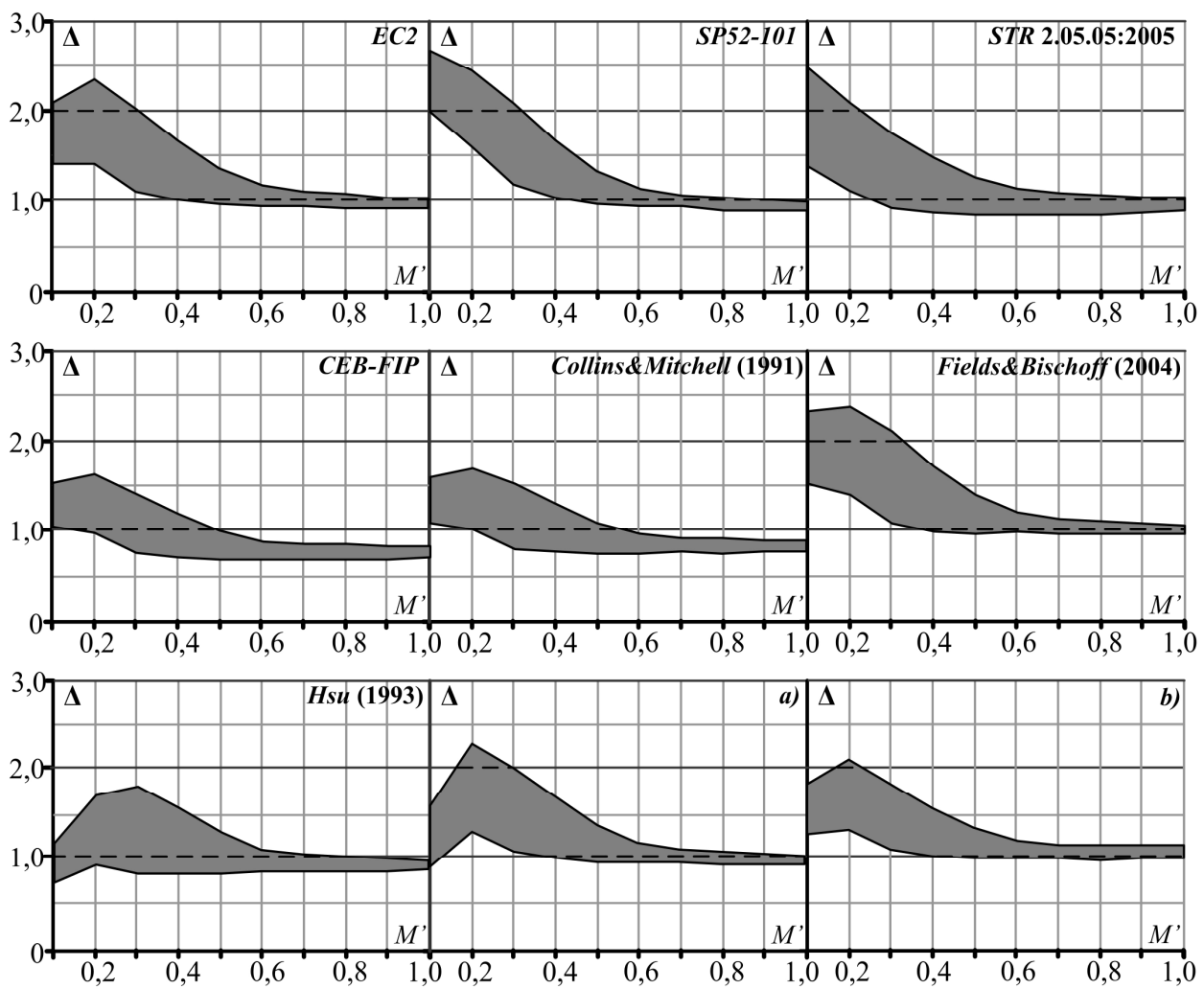

4.10 pav. Santykinès paklaidos $95 \%$ pasikliautinieji intervalai $(\rho<0,5 \%)$

Fig. 4.10. Relative error $95 \%$ confidence intervals $(\rho<0,5 \%)$ 
Deformacijų skaičiavimo tikslumas buvo įvertintas santykinèmis paklaido$\operatorname{mis} \Delta_{i, k}$ :

$$
\Delta_{i, k}=x_{\text {calc }} / x_{o b s}, i=1,2,3, \ldots, 10, k=40,
$$

čia $x_{c a l c}$ ir $x_{o b s}$ atitinkamai - apskaičiuotos bei eksperimentiškai nustatytos tempiamuju gelžbetoninių elementų deformacijos; $i$-osios apkrovos $M^{\prime}$ lygis; k - eksperimentinių sijų skaičius.

Vertinant skaičiavimo metodų tikslumą pagal (4.6) ir (4.7), buvo nustatyti santykinès paklaidos $\Delta_{i, k}$ vidurkis $m_{\Delta}$ bei vidutinis kvadratinis nuokrypis $s_{\Delta}^{2}$. Ilinkių skaičiavimo atitikimas eksperimentiniams duomenims ivvertintas taikant paskliautinujų intervalų metodą (4.8).
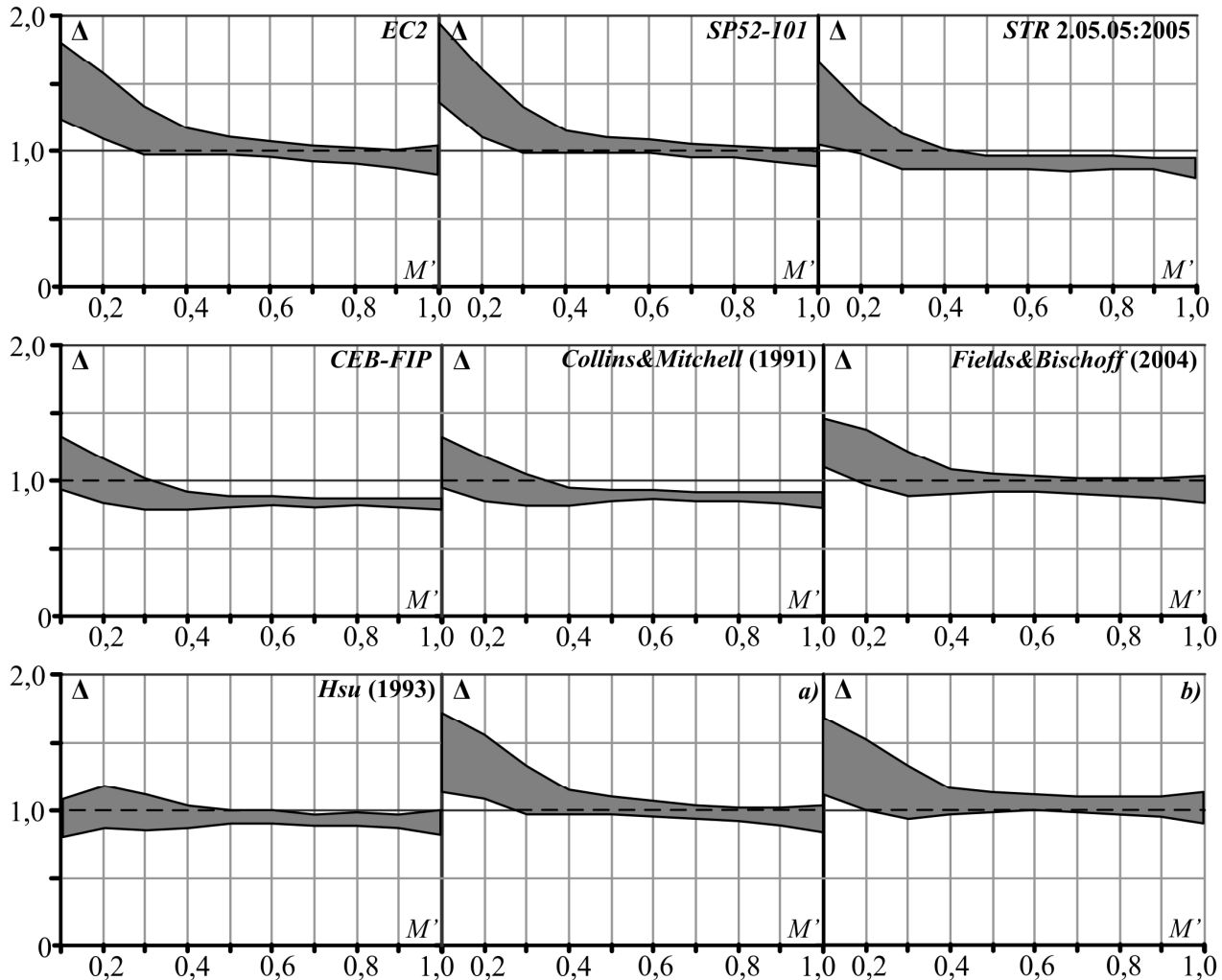

4.11 pav. Santykinès paklaidos $95 \%$ pasikliautinieji intervalai $(0,5 \leq \rho \leq 1,0 \%)$

Fig. 4.11. Relative error $95 \%$ confidence intervals $(0,5 \leq \rho \leq 1,0 \%)$

Analizè parodè, kad deformacijų skaičiavimo tikslumas priklauso nuo tempiamos zonos armavimo koeficiento. Todèl buvo sudaryti trys analizės intervalai: 


$$
\rho<0,5 \%, 0,5 \% \leq \rho \leq 1,0 \% \text { ir } \rho>1,0 \% \text {. }
$$

Pastebèta, kad didžiausią itaką visų metodų tikslumui turi tempiamosios zonos armavimo procentas bei apkrovimo intensyvumas. 4.10-4.12 paveiksluose bei priede B.3 lentelèje pateikti lyginamosios statistikos rezultatai skirtingiems armavimo koeficiento intervalams. Didžiausios paklaidos nustatytos mažai armuotų eksperimentinių duomenų $(\rho<0,5 \%)$ intervale. Santykinès paklaidos vidurkis atskiriems metodams kito ribose: $0,97-1,74$ (EC2), 0,93-2,32 (SP52101), 0,94-1,90 (STR 2.05.05:2005), 0,64-1,27 (CEB-FIP), 0,81-1,33 (Collins ir Mitchell), 0,66-1,90 (Fields ir Bischoff), 0,92-1,26 (Hsu), 0,96-1,75 ( $a$ - pasiūlytasis tempiamojo sustandejjimo modelis lenkiamiesiems gelžbetoniniams elementams), 1,05-1,69 ( $b$ - pasiūlytasis supaprastintas kreivių skaičiavimo metodas).
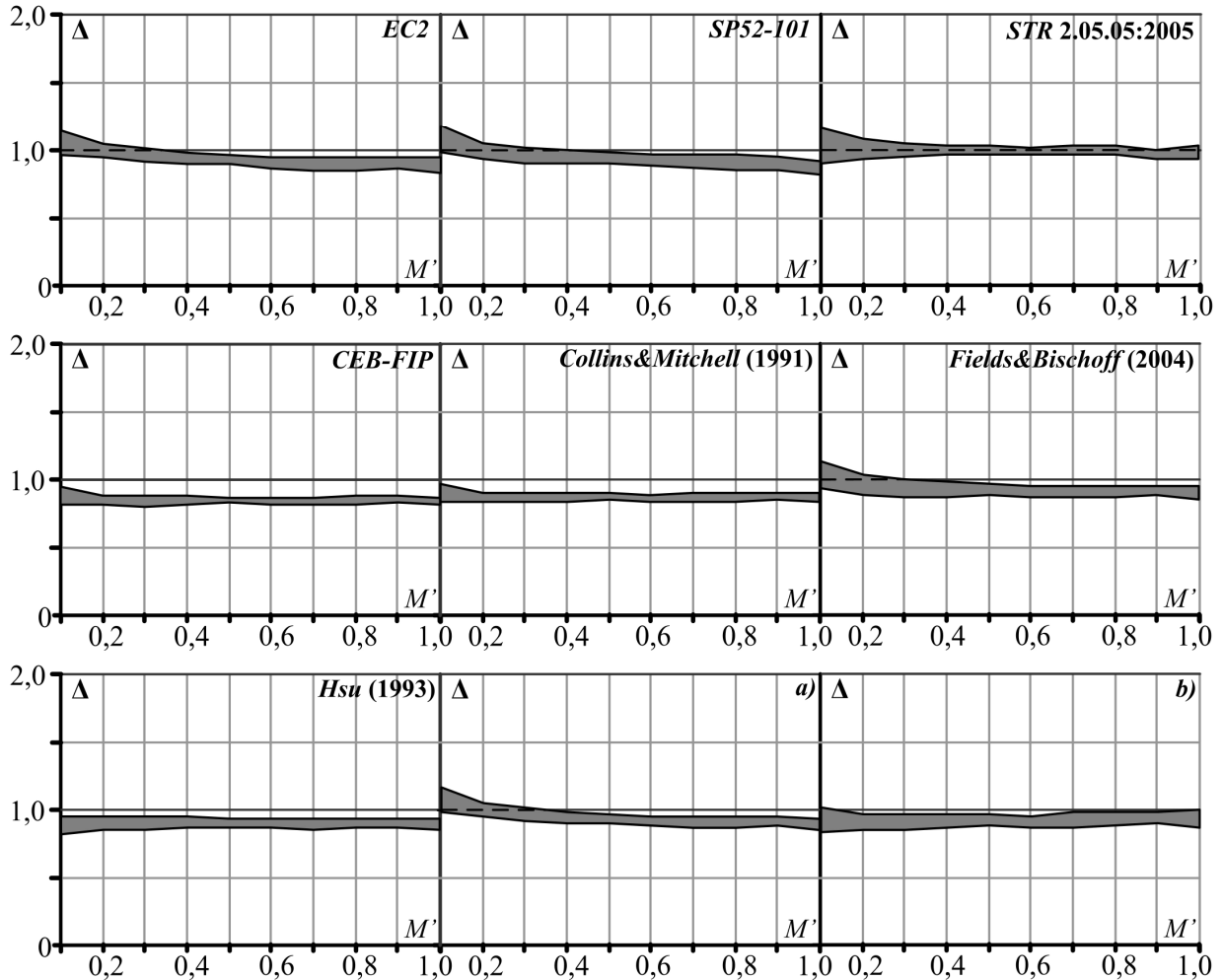

4.12 pav. Santykinès paklaidos $95 \%$ pasikliautinieji intervalai $(\rho>1,0 \%)$

Fig. 4.12. Relative error $95 \%$ confidence intervals $(\rho>1,0 \%)$

Pastebèta, kad didžiausią itaką visų metodų tikslumui turi tempiamosios zonos armavimo procentas bei apkrovimo intensyvumas. 4.10-4.12 paveiksluose bei priede B.3 lentelèje pateikti lyginamosios statistikos rezultatai skirtingiems 
armavimo koeficiento intervalams. Didžiausios paklaidos nustatytos mažai armuotų eksperimentinių duomenu $(\rho<0,5 \%)$ intervale. Santykinès paklaidos vidurkis atskiriems metodams kito ribose: 0,97-1,74 (EC2), 0,93-2,32 (SP52101), 0,94-1,90 (STR 2.05.05:2005), 0,64-1,27 (CEB-FIP), 0,81-1,33 (Collins ir Mitchell), 0,66-1,90 (Fields ir Bischoff), 0,92-1,26 (Hsu), 0,96-1,75 ( $a$ - pasiūlytasis tempiamojo sustandejjimo modelis lenkiamiesiems gelžbetononiams elementams), 1,05-1,69 ( $b$ - pasiūlytasis supaprastintas kreivių skaičiavimo metodas). Tuo tarpu vidutiniškai ir stipriai armuotiems lenkiamiesiems gelžbetoniniams elementams $(\rho>1,0 \%)$ santykinès paklaidos vidurkis buvo: $0,88-1,05$ (EC2), 0,86-1,07 (SP52-101), 0,97-1,03 (STR 2.05.05:2005), 0,83-0,87 (CEBFIP), 0,86-0,90 (Collins ir Mitchell), 0,91-1,03 (Fields ir Bischoff), 0,89-0,90 $(H s u), 0,91-1,08$ ( $a$ - pasiūlytasis tempiamojo sustandejjimo modelis lenkiamiesiems gelžbetoniniams elementams), 0,91-0,94 ( $b$ - pasiūlytasis supaprastintas kreivių skaičiavimo metodas).

\subsubsection{Tempiamojo sustandèjimo diagramos, gautos iš tempiamuju gelžbetoninių elementų, taikymas lenkiamuose elementuose.}

Dažniausiai tyrinètojai lenkiamujų gelžbetoninių elementų įlinkiams skaičiuoti taike supleišèjusiojo betono vidutinių itempių ir vidutinių deformacijų diagramas gautas iš tempiamujų elementų [Careira ir Chu (1986), Bhide (1986), Hsu (1993), Bischoff (1983), Fields ir Bischoff (2004)]. Šiame skirsnyje buvo palyginti ịlinkių skaičiavimo rezultatai su eksperimentiniais duomenimis aprašytais 4.2.2 skirsnyje, taikant skirtingas tempiamojo sustandejjimo diagramas, gautas iš lenkiamujų bei tempiamujuc elementų. Palyginimas atliktas dviems skaičiavimo atvejams. Pirmuoju atveju iš tempiamuju gelžbetoninių elementų gautos tempiamojo sustandejjimo diagramos, ivertintos visame lenkiamojo gelžbetoninio elemento skerspjūvio tempiamosios zonos plote. Antruoju atveju tempiamojo sustandejjimo diagrama buvo taikoma tik efektyviosios zonos plote, kuris nustatomas pagal EC2 (2004) metodika.

Pirmasis skaičiavimo atvejis. 4.12a paveiksle punktyrine linija pavaizduotos tempiamojo sustandejjimo diagramos, gautos iš tempiamuju gelžbetoninių elementų (2.14) dviems armavimo koeficientų atvejams: $\rho=1,0 \%$ ir $\rho=2,0 \%$. Kartu 4.13a paveiksle ištisine linija parodytos tempiamojo sustandejimo diagramos gautos iš lenkiamuju elementų. Taikant pateiktąsias tempiamojo sustandèjimo kreives (4.13a pav.), buvo apskaičiuotos momentų-kreivių diagramos (4.13b pav.). 

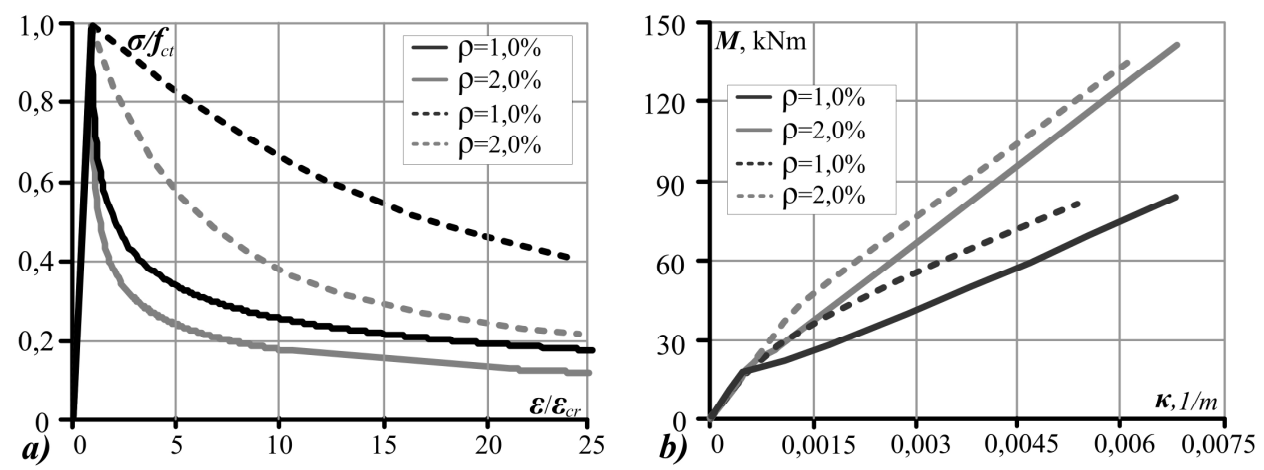

4.13 pav. (a) tempimo sustandèjimo kreivès; (b) apskaičiuotos $M-\kappa$ diagramos

Fig. 4.13. (a) tension stiffening curves; (b) calculated $M-\kappa$ diagrams

Kaip matyti iš $4.13 b$ paveikslo, apskaičiuotieji lenkiamujų gelžbetoninių elementų kreiviai, taikant EC2 metodika, buvo žymiai didesni nei taikant tempiamojo sustandèjimo diagramas, apskaičiuotas iš tempiamujų elementų. Todèl galima padaryti išvada, kad pastarosios diagramos negalima taikyti visoje lenkiamujų elementų tempimo zonoje.

Antruoju skaičiavimo atveju tempiamojo sustandejimo diagrama, gauta iš tempiamujų elementų, ivvertinta tik efektyviajame skerspjūvio plote. Pagal EC2 (2004) skaičiavimo metodiką lenkiamojo gelžbetoninio elemento efektyviosios zonos aukštis $h_{c, e f}$ nustatomas taikant vieną iš trijų sąlygų:

$$
h_{c, e f}<2,5(h-d), h_{c, e f}<(h-d) / 3, h_{c, e f}<h / 2,
$$

čia $h$ - lenkiamojo gelžbetoninio elemento skerspjūvio aukštis; $d$ - skerspjūvio naudingasis aukštis; $x$-neutralioji ašis.

Pastebėtina, kad skaičiavimo rezultatų tikslumui turi armavimo koeficientas ir apkrovos intensyvumas. Kaip ir ankstesnèse analizėse eksperimentiniai duomenys pagal armavimo koeficientą buvo sudalinti $i$ tris grupes (4.18).

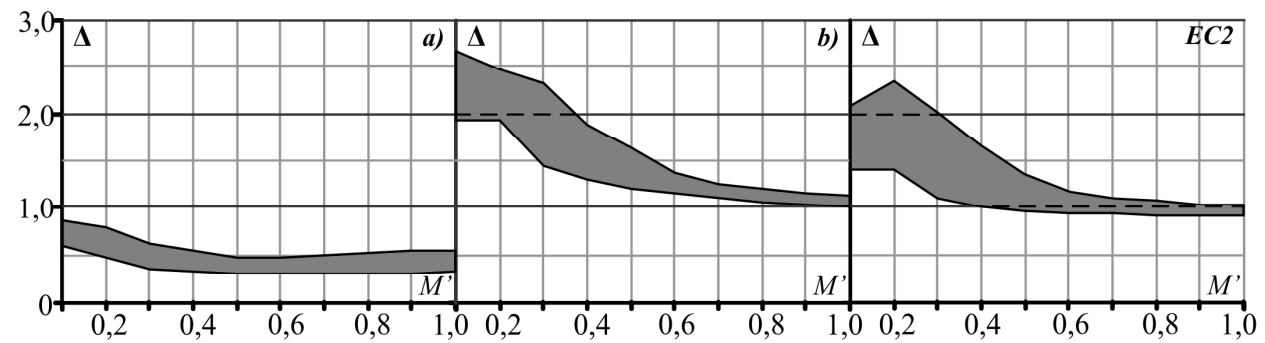

4.14 pav. Santykinès paklaidos $95 \%$ pasikliautinieji intervalai $(\rho<0,5 \%)$

Fig. 4.14. Relative error $95 \%$ confidence intervals $(\rho<0,5 \%)$ 


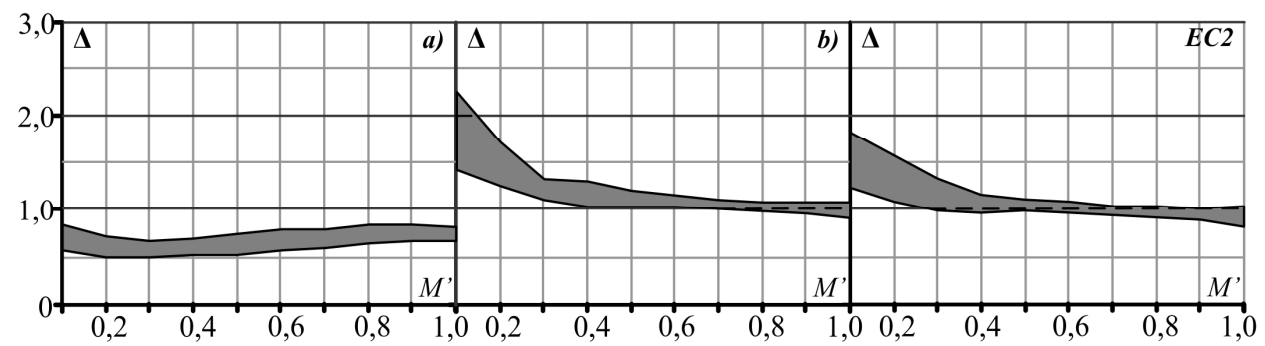

4.15pav. Santykinès paklaidos $95 \%$ pasikliautinieji intervalai $(0,5 \leq \rho \leq 1,0 \%)$

Fig. 4.15. Relative error $95 \%$ confidence intervals $(0,5 \leq \rho \leq 1,0 \%)$

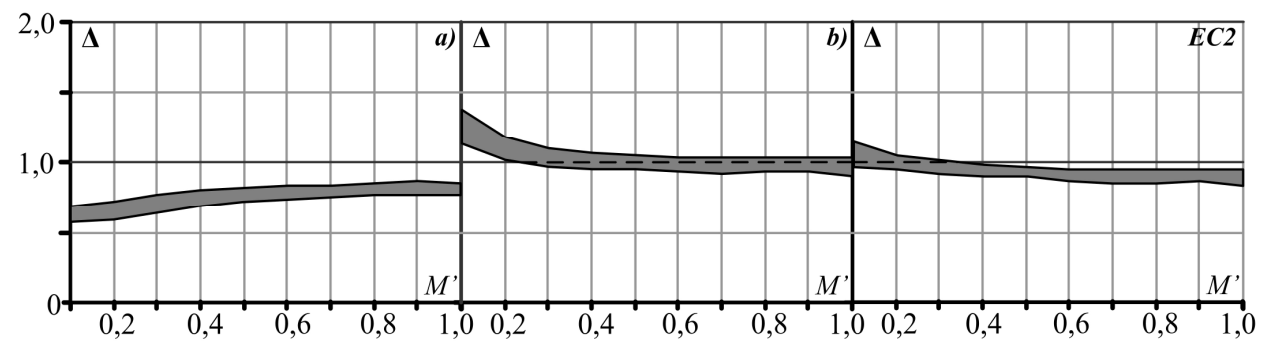

4.16 pav. Santykinès paklaidos $95 \%$ pasikliautinieji intervalai $(\rho>1,0 \%)$

Fig. 4.16. Relative error $95 \%$ confidence intervals $(\rho>1,0 \%)$

Iš 4.14a-4.16a paveikslų ir priede esančios B.4 lentelès matyti, kad tempiamojo sustandejjimo diagramą taikant visoje tempimo zonoje apskaičiuotieji ¡llinkiai visiems armavimo koeficiento intervalams yra gerokai mažesni nei eksperimentiniai ịlinkiai. Priešingai, tempiamojo sustandejjimo diagramą taikant efektyvioje zonoje (4.14b-4.16b pav.) gaunami tikslesni rezultatai, gana artimi EC2 skaičiavimo rezultatams. Tiesa, apkrovos stadijose artimose pleišejimo apkrovai apskaičiuotieji įlinkiai gerokai viršijo eksperimentinius.

\subsection{Lenkiamuju gelžbetoninių elementų deformacijų skaičiavimas, taikant baigtinių elementų programą „Atena”}

Šiame skirsnyje atliktas pagal EC2 metodiką apskaičiuotų ir baigtinių elementų programa „Atena“ sumodeliuotų gelžbetoninių sijų ilinkių palyginimas. Baigtinių elementų modelyje buvo įvertintos netiesinès medžiagų savybès. Armatūra aprašyta dvilinijne $\sigma-\varepsilon$ diagrama (1.1.1 skirsnis), gniuždomasis betonas ivvertintas pagal EC2 metodiką (1.3), tempiamojo sustandejimo diagrama apskaičiuota pagal siūlomają (3.24) išraišką. Skaitinių eksperimentų analizei buvo panaudotas $C 25 / 30$ ir $C 45 / 55$ klasiu betonas bei skirtingi armavimo koefi- 
cientai: $\rho=0,5 \%, \rho=1,0 \%, \rho=2,0 \%$. Gelžbetoninès sijos skaičiuojamoji schema bei skerspjūvio charakteristikos pateiktos 4.17 paveiksle.
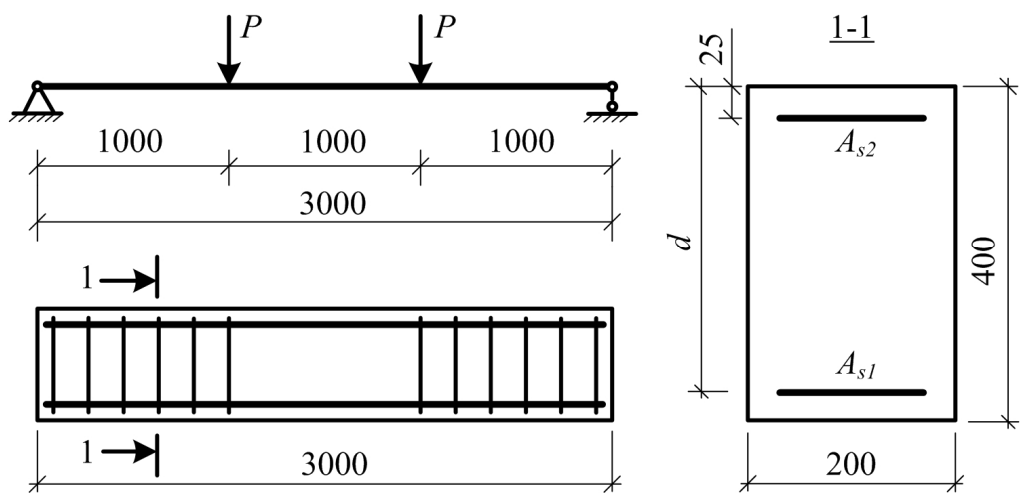

4.17 pav. Sijos eksperimento skerspjūvis ir skaičiuojamoji schema

Fig. 4.17. Cross-section and loading scheme of experimental beam

Dèl simetrijos buvo modeliuojama puse sijos. Dvimačiame baigtinių elementų modelyje panaudoti keturkampiai $6,67 \mathrm{~cm}$ dydžio baigtiniai elementai, kurių mazgai turèjo keturis laisvès laipsnius. Tamprioje stadijoje betonas buvo imamas kaip izotropinè medžiaga. Jam supleišejus jis buvo laikomas ortotropine medžiaga. Analizèje panaudotas fiksuoto plyšio modelis: plyšių atsivėrimo kryptis sutampa su pagrindinių ittempių kryptimi. Armatūra buvo modeliuojama strypiniais baigtiniais elementais, imant idealų sukibimą su betonu. Gelžbetoninès sijos baigtinių elementų modelis ir pleišejimo schema pavaizduoti 4.18 paveiksle.

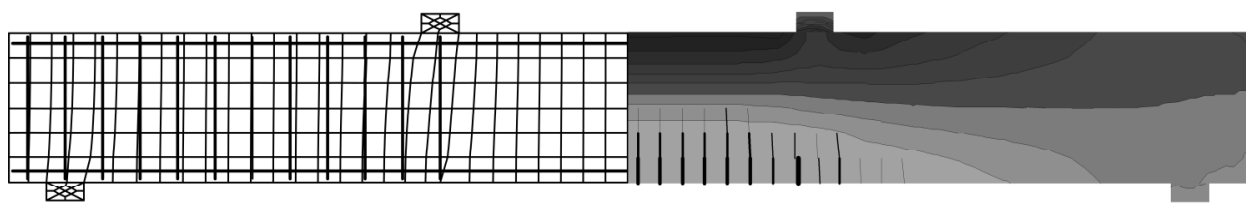

4.18 pav. Sijos baigtinių elementų modelis

Fig. 4.18. Finite element model of a beam

4.19 paveiksle pavaizduotas momentų-kreivių diagramų apskaičiuotų EC2 metodu ir baigtiniu elementų programa „Atena“, rezultatu palyginimas. Kaip matyti iš pateiktų diagramų, gautas geras apskaičiuotujų kreivių sutapimas. 

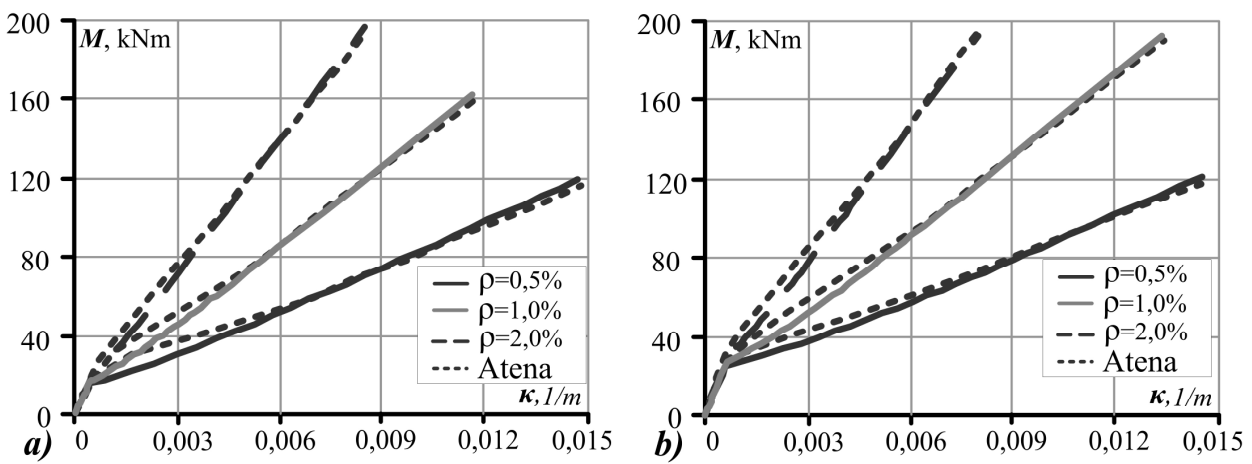

4.19 pav. Apskaičiutų pagal „Atena” ir EC2 metodiką $M-\kappa$ diagramų palyginimas, kai: (a) $C 25 / 30$ ir (b) $C 45 / 55$

Fig. 4.19. Comparison of $M-\kappa$ diagrams calculated by „Atena” and EC2 method, when:

(a) $C 25 / 30$ and (b) $C 45 / 55$

\subsection{Ketvirtojo skyriaus rezultatai ir išvados}

Šiame skyriuje buvo nagrinejjamas pasiūlytujų tempimo sustandejjimo modelių adekvatumas kitu autoriu atliktu eksperimentų bei Euronorrmų skaičiavimo rezultatams. Lyginamoji statistinė analizè susideda iš dviejų dalių. Pirmojoje dalyje atlikta tempiamiesiems elementams gautos tempimo sustandejimo diagramos tikslumas, analizès rezultatus palyginant su literatūroje paskelbtu eksperimentinių tyrimų bei modelių rezultatais. Antrojoje dalyje apskaičiuotieji sijų ilinkiai taikant tempimo sustandejjimo diagramas gautas iš tempiamujų ir lenkiamujų elementų palyginti su eksperimentinių duomenų, Euronormų metodo bei kitų modelių gautaisiais rezultatais.

Gautos tokios išvados:

1. Nustatyta, kad tempiamujų ir lenkiamujų gelžbetoninių elementų deformacijų skaičiavimo metodų tikslumui turi armavimo koeficientas bei apkrovos intensyvumas.

2. Taikant originaliają Euronormų metodika, apskaičiuotos tempiamujų gelžbetoninių elementų deformacijos buvo žymiai mažesnès už eksperimentines. Nevertinant betono traukimosi, mažiau armuotiems elementams $(\rho \leq 1,5 \%)$ apkrovos lygiuose, artimuose pleišejimo ribai, apskaičiuotos deformacijos vidutiniškai tesieke $40 \%$ eksperimentinès reikšmès. Visuose apkrovos intervaluose santykinès paklaidos vidurkis kito nuo 0,40 iki 0,57. Stipriau armuotiesiems elementams gautos kiek mažesnès paklaidos: $0,58-0,80$. Kai betono traukimasis buvo eliminuotas, skaičiavimas geriau atitiko eksperimento rezultatus. Mažiau armuotiems 
$(\rho \leq 1,5 \%)$ ir stipriau armuotiems $(\rho>1,5 \%)$ elementams santykinès paklaidos vidurkis kito ribose: atitinkamai $0,70-0,79$ ir $0,86-0,99$.

3. Tempiamuju elementų atveju, 293 eksperimentinių taškų duomenų imčiai atlikta deformacijų tikslumo skaičiavimo statistine analizè parodè, kad kitų modelių tikslumas priklauso nuo armavimo koeficiento. Mažiau armuotiems elementams santykinès paklaidos vidurkis atskiriems metodams kito ribose: 0,64-0,70 (CEB-FIP), 0,74-1,12 (Hsu), 0,64-0,85 (Collins ir Mitchell), 0,83-0,92 (Fields ir Bischoff). Daugiau armuotiems elementams $(\rho>1,5 \%)$ gauti tokie rezultatai $0,77-0,85(C E B-$ FIP), 0,85-1,08 (Hsu), 0,76-0,91 (Collins ir Mitchell), 0,85-0,94 (Fields ir Bischoff).

4. Atlikus apskaičiuotų ilinkių pagal ịvairius skaičiavimo metodus ir medžiagų modelių palyginamają statistinę analizę, nustatyta, kad didžiausią itaką tikslumui turi tempiamosios zonos armavimo procentas bei apkrovimo intensyvumas. Didžiausios paklaidos nustatytos mažai armuotų eksperimentinių duomenu $(\rho<0,5 \%)$ intervale. Santykinès paklaidos vidurkis atskiriems metodams kito ribose: $0,97-1,74$ (EC2), 0,93-2,32 (SP52-101), 0,94-1,90 (STR 2.05.05:2005), 0,64-1,27 (CEB-FIP), 0,811,33 (Collins ir Mitchell), 0,66-1,90 (Fields ir Bischoff), 0,92-1,26 (Hsu), 0,96-1,75 (a modelis), 1,05-1,69 (b modelis). Tuo tarpu vidutiniškai ir stipriai armuotiems elementams $(\rho>1,0 \%)$ santykinès paklaidos vidurkis buvo: 0,88-1,05 (EC2), 0,86-1,07 (SP52-101), 0,97-1,03 (STR 2.05.05:2005), 0,83-0,87 (CEB-FIP), 0,86-0,90 (Collins ir Mitchell), 0,91-1,03 (Fields ir Bischoff), 0,89-0,90 (Hsu), 0,91-1,08 (a modelis), 0,91-0,94 (b modelis).

5. Taikant tempimo sustandejjimo diagramą gautą iš tempiamujų elementų visoje lenkiamujų elementų tempimo zonoje apskaičiuotieji ilinkiai buvoi iki $40 \%$ mažesni nei eksperimentiniai įlinkiai. Priešingai, tempimo sustandejjimo diagramą taikant efektyvioje zonoje gaunamos iki $10 \%$ paklaidos. Tiesa, apkrovos stadijose artimose pleišèjimo apkrovai apskaičiuotieji ịlinkiai gerokai viršijo eksperimentinius.

6. Pasiūlytieji tempiamojo sustandejjimo modeliai gauti iš tempiamujų ir lenkiamujuc gelžbetoniniu elementų gali būti taikomi skaitiniuose metoduose, skaičiuojant statiškai neišsprendžiamas gelžbetonines konstrukcijas. 



\section{Bendrosios išvados}

1. Euronormu metodika skirta projektuoti statybines konstrukcijas esant nesudètingam įtempių būviui. Deja, normų metodai negali būti taikomi sudètingų konstrukcijų formos ir apkrovimo atvejais. Tokių konstrukcijų analizei taikomi skaitiniai metodai, kuriais gali būti ìvertinti sudètingi gelžbetonio elgsenos aspektai bei netiesinès medžiagų sąvybès. Euronormos pateikia gniuždomojo betono modeli, tačiau nereglamentuoja supleišèjusio tempiamo betono modelio (dar vadinamo tempiamojo sustandejimo modeliu), kuris turi didelę itaką apskaičiuotoms deformacijoms. Todèl taikant Euronormu nuostatas negalima analizuoti sudètingesnių konstrukcijų itempių ir deformacijų būvio.

2. Paprastai tempiamojo sustandejjimo modeliai gaunami iš tempiamujuc gelžbetoninių elementų eksperimentinių tyrimų, o vẻliau taikomi nustatant lenkiamujų elementų deformacijas. Taip apskaičiuojant lenkiamujų elementų deformacijas, gaunamos nemažos paklaidos. Šiame darbe tempiamojo sustandejjimo modeliai, atitinkantys Euronormų nuostatas, buvo gauti ne tik iprastiniu būdu, t. y. iš tempiamujų elementuc, bet ir iš lenkiamujų elementų. Kuriant modeli buvo pritaikytas Vilniaus Gedimino technikos universiteto mokslininkų pasiūlytas modelių kūrimo metodas, kuriuo tempiamojo betono vidutinių itempių ir vidutinių deformaci- 
jų diagramos inkrementiniu skaičiavimu nustatomos iš momentų ir kreivių diagramų.

3. Gautieji tempiamojo betono modeliai sudaryti iš dviejų dalių: kylančiosios tampriosios ir krentančiosios, atitinkančios supleišèjusio betono elgseną. Nustatyta, kad krentančiosios diagramos dalies forma labiausiai priklauso nuo tempiamojo betono stiprio, armavimo koeficiento bei armatūros ir betono tamprumo moduliu santykio.

4. Pasiūlytieji tempiamojo sustandèjimo dèsniai buvo pritaikyti sluoksnių skerspjūvio modelyje nustatant gelžbetoninių elementų tempimo deformacijas bei kreivius. Gauti rezultatai gerai atitiko Euronormų apskaičiuotoms reikšmėms - didžiausia paklaida neviršijo $1 \%$.

5. Nustatyta, kad supleišèjusio tempiamojo betono modeliai tempiamiesiems ir lenkiamiesiems gelžbetoniniams elementams yra skirtingi. Taikant tempiamujuc elementų modeli lenkiamiesiems elementams gautos iki $40 \%$ paklaidos. Paklaidos didèja, mažèjant armavimo koeficientui.

6. Surinktai 293 eksperimentinių taškų duomenų imčiai atlika tempiamujų elementų deformacijų tikslumo skaičiavimo statistinè analizè parodé, kad modeliu tikslumas priklauso nuo armavimo koeficiento ir apkrovos intensyvumo. Mažiau armuotiems elementams santykinès paklaidos vidurkis atskiriems metodams kito ribose: 0,64-0,70 (CEB-FIP), 0,741,12 (Hsu), 0,64-0,85 (Collins ir Mitchell), 0,83-0,92 (Fields ir Bischoff). Daugiau armuotiems elementams $(\rho>1,5 \%)$ gauti tokie rezultatai: 0,77-0,85 (CEB-FIP), 0,85-1,08 (Hsu), 0,76-0,91 (Collins ir Mitchell), 0,85-0,94 (Fields ir Bischoff).

7. Taikant originaliają EC2 metodiką ir nevertinant betono traukimosi, mažiau armuotiems elementams $(\rho \leq 1,5 \%)$ apkrovos lygiuose, artimuose pleišèjimo ribai, apskaičiuotos deformacijos vidutiniškai siekè $40 \%$ eksperimentinès reikšmès. Visuose apkrovos intervaluose santykinès paklaidos vidurkis kito nuo 0,40 iki 0,57. Stipriau armuotiesiems elementams gautos kiek mažesnès paklaidos: $0,58-0,80$. Eliminavus betono traukimąsi mažiau armuotiems $(\rho \leq 1,5 \%)$ ir stipriau armuotiems $(\rho>1,5 \%)$ elementams santykinès paklaidos vidurkis kito ribose: atitinkamai $0,70-0,79$ ir $0,86-0,99$.

8. Atlikus apskaičiuotu ilinkių pagal îvairius skaičiavimo metodus ir medžiagų modelių palyginamają statistinę analizę, nustatyta, kad didžiausią itaką tikslumui turi tempiamosios zonos armavimo procentas bei apkrovimo intensyvumas. Didžiausios paklaidos nustatytos mažai armuotų eksperimentinių duomenų $(\rho<0,5 \%)$ intervale, kai santykinès paklaidos vidurkis atskiriems metodams kito ribose: 0,97-1,74 (EC2), 0,932,32 (SP52-101), 0,9-1,90 (STR 2.05.05:2005), 0,64-1,27 (CEB-FIP), 
0,81-1,33 (Collins ir Mitchell), 0,66-1,90 (Fields ir Bischoff), 0,92-1,26 (Hsu). 



\section{Literatūra ir šaltiniai}

ACI Committee 201. 2001. Guide to Durable Concrete, ACI 201.2R-01. Farmington Hills, Michigan: ACI. 41 p.

ACI Committee 209. 2008. Guide for Modeling and Calculating Shrinkage and Creep in Hardened Concrete, ACI 209.2R-08. Farmington Hills, Michigan: ACI. 48 p.

ACI Committee 318. 2008. Building Code Requirements for Structural Concrete, ACI 318-08 and Commentary. Farmington Hills, Michigan: ACI. 471 p.

Acker, P.; Ulm, F. J. 2001. Creep and shrinkage of concrete: physical origins and practical measurements, Nuclear Engineering and Design 203(2-3): 143-158.

AIJ (Architectural Institute of Japan). 1991. AIJ Standards for Structural Calculation of Steel Reinforced Concrete Structures (English translation of 1987 edition). Tokyo: AIJ. $104 \mathrm{p}$.

Abrishami, H.; Mitchell, D. 1996. Influence of Splitting cracks on tension stiffening, ACI Structural Journal 93(6): 703-710.

Achyutha, H.; Paramasivam, V., Hari, K., Sree Harsha, K., Koteswara Rao, P. C., Sivathanu Pillai, C. 1999. Constitutive law for reinforced/prestressed concrete linear members subjected to uniaxial tension, Transactions of the $15^{\text {th }}$ International Conference on Structural Mechanics in Reactor Technology, Seoul, Korea:15-20. 
Al-Fayadh, S. 1997. Cracking behaviour of reinforced concrete tensile members, Division of Concrete Structures, Chalmers University of Technology, Goteborg, Sweden., master thesis 97:3.

Al-Zaid, R. Z.; Al-Shaikh, A. H., Abu-Hussein, M. M. 1991. Effect of loading type on the effective moment of inertia of RC beams, ACI Structural Journal vol. 88: 184-190.

Ashour, S. A. 2000. Effect of compressive strength and tensile reinforcement ratio on flexural behaviour of high-strength concrete beams, Engineering Structures 22(5): 413423.

Bazant, Z. P.; Gambarova, P. 1980. Rough Cracks in Reinforced Concrete, Journal of Structural Division, New York: ASCE, v. 106: 819-842.

Bazant, Z. P.; Oh, B. 1983. Crack band theory for fracture of concrete, Materials and Structures (RILEM) 16(93): 155-177.

Belarbi, A.; Hsu, T. T. C. 1991. Constitutive laws of reinforced concrete in biaxial tension - compression, Rses. Rep. UHCEE 91-2, Univ. of Houston, Tex.

de Borst, R.; Nauta, P. 1985. Non-orthogonal cracks in smeared finite element model, Engrg. Computations 2: 35-46.

Bhide, S. B. 1986. Reinforced concrete elements in shear and tension, PhD thesis, University of Toronto.

Bischoff, P. H. 1983. Response of Prestressed Concrete Tension Members. M. Eng. thesis. McGill University, Montreal. 122 p.

Bischoff, P. H. 2001. Effects of shrinkage on tension stiffening and cracking in reinforced concrete, Canadian Journal of Civil Engineering 28(3): 363-374.

Bischoff, P. H.; Mac Laggan, D. A. 2006. Bond and tension stiffening in concrete tension members with plain reinforcement, in Proc. of $1^{\text {st }}$ International Structural Specialty Conference of the Canadian Society for Civil Engineering, Calgary, 2006, (CD) 10 p.

Bischoff, P. H. 2008. Discussion of "Tension stiffening in lightly reinforced concrete slabs" by R. I. Gilbert, ASCE Journal of Structural Engineering 134(7): 1259-1260.

Bischoff, P. H.; Johnson, R. D. 2007. Effect of shrinkage on short-term deflection of reinforced concrete beams and slabs, in Structural Implications of Shrinkage and Creep of Concrete, ACI SP 246: 167-180.

Bischoff, P. H.; Mac Laggan, D. A. 2006. Bond and tension stiffening in concrete tension members with plain reinforcement, in Proc. of $1^{\text {st }}$ International Structural Specialty Conference of the Canadian Society for Civil Engineering, Calgary, 2006, (CD) 10 p.

Borosnyói, A.; Balázs, L. G. 2005. Models for flexural cracking in concrete: the state of the art, Structural Concrete 6(2): 53-62.

Branson, D. E. 1963. Instantaneous and Time-Dependent Deflections of Simple and Continuous Reinforced Concrete Beams. HPR Report 7(1). Alabama Highway Department, Bureau of Public roads. $78 \mathrm{p}$. 
Careira, D. J.; Chu K.-H. 1986. Stress-strain relationship of reinforced concrete in tension, ACI Journal Proceedings 83(1): 21-28.

CEB-FIP (Comité Euro International du Béton; Fédération International de la Précontraint). 1978. CEB-FIP Model Code for Concrete Structures. CEB Bulletin d'Information 124/125E. 348 p.

CEB-FIP (Comité Euro International du Béton; Fédération International de la Précontraint). 1990. High Strength Concrete. SR 90/1. 61 p.

CEB-FIP (Comité Euro International du Béton; Fédération International de la Précontraint). 1991. CEB-FIB Model Code 1990: Design Code. London: Thomas Telford. $437 \mathrm{p}$.

CEB-FIP (Comité Euro International du Béton; Fédération International de la Précontraint). 1997. Serviceability Models. Behaviour and Modelling in Serviceability Limit States Including Repeated and Sustained Loads. Bulletin d'Information 235. Lausanne: CEB. 280 p.

CEN (Comité Européen de Normalisation). 2004. Eurocode 2: Design of Concrete Structures - Part 1: General Rules and Rules for Buildings, EN 1992-1-1:2004. Brussels: CEN. 230 p.

Cervenka, V. 1985. Constitutive model for cracked reinforced concrete, ACI Journal Proceedings 82(6): 877-882.

Cervenka, V. 1995. Mesh sensitivity effects in smeared finite element analysis of concrete fracture, in Proc. of The Second International Conference Fracture Mechanics of Concrete Structures (FraMCoS-2). Freiburg: AEDIFICATIO Publishers: 1387-1396.

Cervenka, V. 2002. Computer simulation of failure of concrete structures for practice, in Proc. First FIB Congress, Concrete Structures in 21 Century, Osaka, Japan, 2002, 63.

Cervenka, J.; Cervenka, V.; Eligehausen, R. 1998. Fracture-plastic model for concrete. Application to analysis of powder actuated anchors, in Proc. of the Third International Conference on Fracture Mechanics of Concrete Structures (FraMCoS 3). Gifu, Japan, 1998, 2: 1107-1117.

Cervenka, V.; Cervenka, J.; Pukl, R. 2002. ATENA - A tool for engineering analysis of fracture in concrete, Sadhana 27(4): 485-492.

Cervenka, J.; Chandra Kishen, J. M.; Saouma, A. E. 1998. Mixed mode fracture of cementitious biomaterial interfaces. Part II: Numerical simulation, Engineering Fracture Mechanics 60(1): 95-107.

Cervenka, V.; Pukl, R. 1994. SBETA analysis of size effect in concrete structures, in Size effect in Concrete Structure. London: E \& F N Spon, 323-333.

Cervenka, V.; Pukl, R. 1995. Mesh sensitivity effects in smeared finite element analysis of concrete structures, in Proc. of the Second International Conference on Fracture Mechanics of Concrete Structures (FraMCoS 2). ETH Zurich, Switzerland, 1995, 13871396. 
Cervenka, V.; Pukl, R.; Eligehausen, R. 1990. Computer simulation of anchoring technique in reinforced concrete beams, in Proc. of the Second International Conference on Computer Aided Analysis and Design of Concrete Structures. Swansea: Pineridge Press, $1-19$.

Clark, L. A.; Speirs, D. M. 1978. Tension Stiffening in Reinforced Concrete Beams and Slabs under Short-Term Load. Technical Report 42.521. Cement and Concrete Association. 19 p.

Clark, L. A.; Cranston, W. B. 1979. The influence of bar spacing on tension stiffening in reinforced concrete slabs, Proceedings International Conference on Concrete Slabs, Dundee, 118-128.

Collins, M. P.; Mitchell, D. 1991. Prestressed Concrete Structures. Englewood Cliffs, New York: Prentice-Hall Inc. 766 p.

Collins, M.P. 1979. Stress-strain characteristics of diagonally cracked concrete, Internacional Association for Bridge and Structural Engineering, IABSE Vol. 29, 27-34.

Damjanic, F.; Owen, D. R. J. 1984. Practical considerations for modelling of post cracking concrete behaviout for finite element analysis of reinforced concrete structures. Computer Aided Analysis and Design of Concrete Structures, Pineridge Press, Swansea, 693-706.

Darwin, D.; Barham, S.; Kozul, R.; Luan, S. 2001. Fracture energy of high-strength concrete, ACI Materials Journal 98(5): 410-417.

Dilger, W. H.; Koch, R.; Kowalczyk, R. 1984. Ductility of plain and confined concrete under different strain rates, ACI Journal Proceedings 81(1): 73-81.

Dugdale, D. S. 1960. Yielding of steel sheets containing slits, Journal of the Mechanins and Physics of Solids 8(2): 100-104.

Ebead, U. A.; Marzouk, H. 2005. Tension stiffening model for FRP-strengthened RC concrete two-way slabs, Material and Structures (RILEM) 38(276): 193-200.

Eckfeldt, L. 2005. Possibilities and Limitations of the Computation of Crack Widths in Variable Structural Situations (Möglichkeiten und Grenzen der Berechnung von Rissbreiten in Veränderlichen Verbundsituationen). PhD dissertation. Dresden Technical University. $440 \mathrm{p}$.

Edwards, A. D.; Yannopoulos, P. J. 1979. Local bond-stress to slip relationship for hot rolled deformed bars and mild steel plain bars, ACI Journal Proceedings 76(3): 405420 .

Elices, M.; Guinea, G. V.; Gomez, J.; Planas. J. 2002. The cohesive zone model: advantages, limitations and challenges, Engineering Fracture Mechanics 69(2): 137-163.

Elices, M.; Planas. J. 1989. Material models, in Fracture Mechanics of Concrete Structures. London: Chapman \& Hall, 16-62.

Evans, R. H.; Marathe, M. S. 1968. Micro-cracking and stress-strain curves for concrete in tension, Material and Structures (RILEM) 1(1): 61-64. 
Esfahani, M. R.; Rangan, B. V. 1998. Local bond strength of reinforcing bars in normal strength and high - strength concrete (HSC), ACI Structural Journal vol. 95: 272-280.

Fields, K.; Bischoff, P. H. 2004. Tension stiffening and cracking of high-strength reinforced concrete tension members, ACI Structural Journal 101(4): 447-456.

Figarovskij, V. V. 1962. Experimental Investigation of Stiffness and Cracking of Reinforced Concrete Flexural Members Subjected to Short-Term and Long-Term Loading (Экспериментальное исследование жёсткости и трещиностойкости изгибаемых железобетонных элементов при кратковременном и длительном действии нагрузки). PhD dissertation. Moscow: NIIZhB. 210 p. (In Russian).

Fischer, G.; Li, V. C. 2002. Influence of matrix ductility on the tension - stiffening behavior of steel reinforced engineered cementitious composites (ECC), ACI Structural Journal vol. 99: 104-111.

Foster, S. J.; Budiono, B.; Gilbert, R. I. 1996. Rotating crack FE model for reinforced concrete structures, Computers \& Structures 58(1): 43-50.

Foster, S. J.; Marti, P. 2003. Cracked membrane model: Finite element implementation, ASCE Journal of Structural Engineering 129(9): 1155-1163.

Gambarova, P.; Rosati, Zasso, B. 1989. Steel-to-concrete bond after concrete splitting: constitutive laws and interface deterioration, Materials and Structures, Vol. 22: 347-356.

Ghali, A. 1993. Deflections of RC members: a Critical review, ACI Structural Journal vol. 90: 364-373.

Gilbert, R. I.; Warner, R. F. 1978. Tension stiffening in reinforced concrete slabs, Journal of the Structural Division 104(12): 1885-1900.

Gilbert, R. I. 1999. Deflection calculation for RC structures - Why we sometimes get it wrong, ACI Structural Journal 96(6): 1027-1032.

Gilbert, R. I. 2001. Shrinkage, cracking and deflection - the serviceability of concrete structures, Electronic Journal of Structural Engineering 1: 15-37.

Gilbert, R. I.; Wu, H. Q. 2008. An experimental study of tension stiffening in reinforced concrete members under short-term and long-term loads, UNICIV Report No. R-449.

Giuriani, E. 1981. Experimental investigation on the bond-slip law of deformedbars in concrete, IABSE Colloquium Delft, Advanced Mechanics of Reinforced Concrete, Rep. of the Working Commissions, Vol. 34: 121-142.

Gribniak, V.; Kaklauskas, G. 2004. Statistical deflection analysis of RC Beams by different calculation methods, in Proc. of the Seventh Lithuanian Conference of Young Scientists Science - Future of Lithuania. Vilnius: Technika, 94-99. ISBN 9986-05-775-2.

Gribniak, V.; Girdzius, R. 2005. Mesh dependence on deformations of tensile reinforced concrete members (Baigtinių elementų dydžio ir formos įtaka tempiamujų G/B elementų deformacijų skaičiavimo rezultatams), in Proc. of the Eighth Lithuanian Conference of Young Scientists Science - Future of Lithuania. Vilnius: Technika, 181-186 (in Lithuanian). 
Gribniak, V.; Bacinskas, D.; Kaklauskas, G. 2006. Numerical simulation strategy of bearing reinforced concrete tunnel members in fire, The Baltic Journal of Road and Bridge Engineering 1(1): 5-9.

Gribniak, V.; Kaklauskas, G.; Bacinskas, D. 2007a. State-of-art review on shrinkage effect on cracking and deformations of concrete bridge elements, The Baltic Journal of Road and Bridge Engineering 2(4): 183-193.

Gribniak, V.; Bacinskas, D.; Kaklauskas, G. 2007b. Non-linear modelling of reinforced concrete beams subjected to fire, in Proc. of the International COST-C26 Workshop Urban Habitat Constructions under Catastrophic Events. Prague: Czech Technical University, 53-58.

Gribniak, V.; Kaklauskas, G.; Bacinskas, D. 2007c. Experimental investigation of deformations of lightly reinforced concrete beams, in Proc. of the Ninth International Conference Modern Building Materials, Structures and Techniques. Vilnius: Technika, 2: 554-562.

Gribniak, V.; Kaklauskas, G., and Bacinskas, D. 2008. Shrinkage in reinforced concrete structures: A computational aspect, Journal of Civil Engineering and Management, 14(1), 49-60.

Gribniak, V. 2009. Shrinkage influence on tension stiffening of concrete structures. $\mathrm{PhD}$ dissertation. Vilnius, Technika. $145 \mathrm{p}$.

Grossman, J. S. 1981. Simplified computations for effective moment of inertia (ie) and minimum thickness to avoid deflection computations, ACI Journal Proceedings 6(78): 423-439.

Gvozdev, A. A.; Dmitrijev, S. A.; Nemirovskij, J. M. 1962. On deflection calculation of reinforced concrete structures according to new design code SNiP II-V.I-62 (O расчете прогибов железобетонных конструкций по проекту новых норм СНиП II-B.I-62), Beton i Zelezobeton 6: 245-250 (in Russian).

Gupta, A. K.; Maestrini, S.R. 1989. Post - cracking behavior of membrane reinforced concrete elements including tension - stiffening, Journal of Structural Engineering, New York: ASCE, v. 115: 957-976.

Gushcha, Yu. P. 1967. Investigation of Elastic-Plastic Behaviour of Flexural Concrete Beams Reinforced with Deformed Bars (Исследование изгибаемых железобетонных элементов при работе стержневой арматуры в упруго-пластической стадии). $\mathrm{PhD}$ dissertation. Concrete and Reinforced Concrete Research and Technological Institute (NIIZhB), Moscow. 210 p. (in Russian).

Hsu, T. C. T. 1993. Unified Theory of Reinforced Concrete, CRC Press, Inc., 336 p.

Hognestad, H. E.; Hanson, N. W.; Mc Henry, D. 1955. Concrete stress distribution in ultimate strength design, ACI Journal Proceedings 52(12): 455-480.

Hughes, B. P.; Chapman, G. P. 1966. The deformations of concrete and microconcrete in compression and tension with particular reference to aggregate size, Magazine of Concrete Research 18(54): 19-24. 
Jiang, D. H.; Shah, S. P.; Andonian, A. T. 1984. Study of the transfer of tensile forces by bond, ACI Structural Journal 81(3): 251-259.

Kaklauskas, G. 2001. Integral Flexural Constitutive Model for Deformational Anglysis of Concrete Structures. Vilnius: Technika. 140 p.

Kaklauskas, G.; Gribniak, V. 2005. Effects of shrinkage on tension stiffening in RC members, Proc. of the fib Symposium Structural Concrete and Time. Grafikar Sociedad, La Plata, 1, 453-460.

Kaklauskas, G.; Gribniak, V.; Bacinskas, D.; Vainiunas, P. 2009. Shrinkage influence on tension stiffening in concrete members, Engineering Structures, 31(6), 1305-1312.

Kaklauskas, G.; Bacinskas, D.; Gribniak, V.; Geda, E. 2007a. Mechanical simulation of reinforced concrete slabs subjected to fire, Technological and Economic Development of Economy 13(4): 295-302.

Kaklauskas, G.; Burtzev, B. I.; Gribniak, V. 2007b. Derivation of material diagrams from tests of reinforced concrete beams, in Proc. of the Eleventh International Scientific and Practical Conference of Students, Post-Graduates and Young Scientists Modern Techniques and Technologies (MTT 2005). Piscataway: IEEE, 122-125.

Kaklauskas, G.; Cervenka, V.; Cervenka, J.; Vainiunas, P.; Gribniak, V. 2004. Deflection calculation of RC beams: finite element software versus analytical and design code methods, in Proc. of the Tenth International Conference on Computing in Civil and Building Engineering (ICCCBE-X). Weimar: VDG, 8 p. (CD).

Kaklauskas, G.; Christiansen, M. B.; Bacinskas, D.; Gribniak, V. 2005. New Method for Deformation Analysis of Reinforced Concrete Structures (Naujo inžinerinio gelžbetoniniu elementu deformaciju skaičiavimo metodo kūrimas), Technical Report Nr. T-05127. Vilnius, VGTU. 33 p.

Kaklauskas, G.; Christiansen, M. B.; Bacinskas, D.; Gribniak, V. 2008. Constitutive Model for Reinforced Concrete Members Taking into Account Concrete Creep and Shrinkage at Pre-Loading Stage (Gelžbetoniniu elementu deformaciju modelis, ivertinantis betono susitraukimq ir valkšnuma iki eksploatacineje stadijoje), Technical Report NR. T-08024. Vilnius, VGTU. 46 p.

Kaklauskas, G.; Ghaboussi, J. 2001. Stress-strain relations for cracked tensile concrete from RC beam tests, ASCE Journal of Structural Engineering 127(1): 64-73.

Kankam, C. K. 1997. Relationship of bond stress, steel stress, and slip in reinforced concrete, ASCE Journal of Structural Engineering 123(1): 79-85.

Kaplan, M. F. 1961. Crack propagation and the fracture of concrete, ACI Journal Proceedings 58(11): 591-610.

Kent, D. C.; Park, R. 1971. Flexural members with confined concrete, ASCE Journal of the Structural Division 97(7): 1969-1990.

Kesler, C. E.; Naus, D. J.; Lott, J. L. 1972. Fracture mechanics - its applicability to concrete, in Proc. of the International Conference on the Mechanical Behavior of Materials, Kyoto, 1971, IV: 113-124. 
Kolmar, W. 1986. An Approach of the Force Transfer throughout Cracks by the Nonlinear Finite Element Analysis of the Reinforced Concrete Items. PhD dissertation. Darmstadt: T. H. 94 p. (in German).

Kudzys, A; Notkus, A. J. 1978. Calculation of wall panel structures considering nonlinear behaviour of concrete and pesence of reinforcement, Contributions to the IAAS Symposium 1978 Darmstadt "Nonlinear Behaviour of Reinforced Concrete Spatial Structures”. Werner-Verlag, Dusseldorf: 139-149.

Kupliauskas, R.; Notkus, A. J. 1987. Pilnos betono tempimo diagramos eksperimentinis tyrimas, Reinforced Concrete Structures, LAM MD, Nr. 15: 83-89 (in Russian).

Kuzcynski, W., Gaszynski, S., Wlasek, A. 1975 Uproszona metoda oliczania ugiec elementov želbetovych, Inžynieria i budownictvo, Warszava, Nr.7: 497-503.

Kwak, H.-G.; Song, J.-Y. 2002. Cracking analysis of RC members using polynomial strain distribution function, Engineering Structures 24(4): 455-468.

Lackner, R.; Mang, H. A. 2003. Scale transition in steel-concrete interaction. Part I: Model, ASCE Journal of Engineering Mechanics 129(4): 393-402.

Lemnitzer, L.; Eckfeldt, L.; Lindorf, A.; Curbach, M. 2008. Biaxial tensile strength of concrete - answers from statistics, in Proc. of the International fib Symposium Tailor Made Concrete Structures: New Solutions for Our Society, Amsterdam, The Nederland, 2008. UK: CRC Press/Balkema, 1101-1102.

Leonhardt, F. 1988. Cracks and crack control in Cocrete Structure, PCI Journal: 124145.

Leutbecher, T.; Fehling, E. 2009. Crack formation and tensile behaviour of concrete members reinforced with rebars and fibres exemplified by ultra-high-performance concrete Part 1: Crack mechanical relationships, Beton und Stahlbetonbau 104(6): 357-367 (in German).

Liu, Y.; Teng, S.; Soh, C. K. 2008. Three-dimensional damage model for concrete. Part I: Theory, ASCE Journal of Engineering Mechanics 134(1): 72-81.

Litton, R. W. 1974. A contribution to the analysis of concrete structures under cyclic loading, Dissertation presented to the University of California at Berkeley, Calif,, in partial fulfillment of the requirements for the degree of Doctor of Philosophy.

Lutz, L.A.; Gergely, P. 1967. Mechanizm of bond and slip of deformed bars in concrete, ACI Journal Proceedings, 64(11), pp. 711-721.

Mansur, M. A.; Chin, M. S.; Wee, T. H. 1997. Flexural behavior of high-strength concrete beams, ACI Structural Journal 94(6): 663-674.

Marcinkovich, C.; Olsen, K. 2003 On the implementation of perfectly matched layers in a three-dimensional fourth-order velocity-stress finite difference scheme, J. Geophy. Res., 108, B5, ESE 18-1-18-16.

Marciukaitis, G. 1978. Application of the complete diagrams of materials $\sigma-\varepsilon$ to analyze the elasto-plastic workability of the reinforced polymer impregnated concrete structures 
by electronic compute, in 8 International Kongres Anwendung Match. Inginieurwissenschaften. Weimar: Rahmenthema: 77-82.

Marciukaitis, G.; Balevicius, R. 2009. Sluoksniuotujų konstrukcijų itempių ir deformacijų būvio bei valkšnumo analize, veikiant ilgalaikei apkrovai, Engineering Structures and Technologies. Vilnius: Technika, 1(3): 123-134.

Marciukaitis, G.; Jonaitis, B.; Papinigis, V. Valivonis, J. 2007a. Gelžbetoniniu konstrukciju projektavimas pagal Euronormas. Vilnius. Technika. 339 p.

Marciukaitis, G.; Jonaitis, B.; Valivonis, J. 2006a. Analysis of deflections of composite slabs with profiled sheeting up to the ultimate moment, Journal of Constructional Steel Research, 62(12): 1264-1269.

Marciukaitis, G.; Vainiunas, P.; Valivonis, J.; Jonaitis, B. 2006b. Analysis of longitudinal shear behaviour for composite steel and concrete slabs, Journal of Constructional Steel Research, 62(8): 820-830.

Marciukaitis, G.; Valivonis, J.; Bareisis, J. 2007b. An analysis of the joint operation of a CFRP concrete in flexural elements, Mechanics of Composite Materials, 43(5): 467478.

Murashev, V. I. 1950. Crack Resistance, Stiffness and Strength of Reinforced Concrete (Трещиноустойчивость, жёсткость и прочность железобетона). Moscow: Маshinostroiizdat. 268 p. (in Russian).

Nejadi, S. 2005. Time-Dependent Cracking and Crack Control in Reinforced Concrete Structures. PhD dissertation. University of New South Wales. 390 p.

Ngo, D.; Scordelis, A. C. 1967. Finite element analysis of reinforced concrete beams, Journal of American Concrete Institute V. 64, No 3.:152-163.

de Nicolo, B.; Pani, L.; Pozzo, E. 1994. Strain of concrete at peak compressive stress for a wide range of compressive strengths. Materials and Structures 5(27), 206-210.

Notkus, A. J. 1982. Descending Branch of tensile concrete diagrams and stress distribution in structures. Increase in strenght and durability of reinforced concrete Structures, Reinforced Concrete Structures, LAM MD, Nr. 12: 7 (in Russian).

Ouyang, C.; Wollrab, E.; Kulkarni, S. M.; Shah, S. P. 1997. Prediction of cracking response of reinforced concrete tensile members, Journal of Structural Engineering 123(1): 70-78.

Pelessone, D.; Baum, J. D., Lohner, R., Charman, C., M., Baylot, J., T. 2003. Convergence study for the discrete particle method, In Computational Fluid and Solid Mechanics: Proceedings Second MIT Conference on Computional Fluid and Solid Mechanics.

Piyasena, R. 2002. Crack Spacing, Crack Width and Tension Stiffening Effect in Reinforced Concrete Beams and One-Way Slabs. PhD Dissertation. School of Engineering, Griffith University. 370 p.

Popovics, S. A. 1973. Numerical approach to the complete stress - strain curve of concrete, Cement and Concrete Research, 3(5): 553-599. 
Prakhya, G. K. V.; Morley, C. T. 1990. Tension-stiffening and moment-curvature relations of reinforced concrete elements, ACI Structural Journal 87(5): 597-605.

Rangan, B. V. 1982. Control of deflections by allowable span - depth ratios, ACI Structural Journal 79 (5): 372-377.

Rashid, Y. R. 1968. Analysis of prestressed concrete pressure vessels, Nuclear Engineering, 7: 334-344.

RILEM TC 148-SSC. 1997. Strain-softening of concrete in uniaxial compression, Materials and Structures Vol. 30: 195-209.

Рокач, В. С. 1975. К теории деформации железобетона, Бетон и железобетон (5): 35-35. (in Russian).

Rots, J. G. 1988. Computational Modeling of Concrete Structures. PhD dissertation. Delft University of Technology, Delft, The Netherlands. 127 p.

Rozembliumas, A. M. 1964. Calculation methods for revealing stress state of reinforce concrete sections, weakening by the cracks (Методы расчета по выявлению напряженного состояния железобетонных сечений, ослабленных трещиной). Stroitelstvo i Archetiktura, 4. Kaunas.

Ruiz, M. F.; Mattoni, A.; Gambarova, P. G. 2007. Analytical modeling of the pre- and postyield behavior of bond in reinforced concrete, ASCE Journal of Structural Engineering 133(10): 1364-1372.

Sato, Y.; Tadokoro, T.; Ueda, T. 2004. Diagonal tensile failure mechanism of reinforced concrete beams, Journal of Advanced Concrete Technology 2(3): 327-341.

Sato, R.; Maruyama, I.; Sogabe, T.; Sogo, M. 2007. Flexural behavior of reinforced recycled concrete beams, Journal of Advanced Concrete Technology 5(1): 43-61.

Saenz, L. P. 1964. Discussion of equation for the stress - strain curve of concrete - by Desayi and Krishnan, Aci Journal 61(6): 1229-1235.

Shah, S. P.; Ahmad, S. H. 1985. Structural properties of high strength concrete and its implication for precast prestressed concrete, PCI Journal 30(4-6): 92-119.

Shi, Z.; Suzuki, M.; Ohtsu, M. 2004. Discrete modeling of crack interaction and localization in concrete beams with multiple cracks, Journal of Advanced Concrete Technology, Vol. 2 No. 1: 101-111.

SP 52-101. 2003. Concrete and reinforced concrete structures without prestressing (Бетонные и железобетонные конструкции без предварительного напряжения арматуры), Moscow. (in Russian).

STR 2.05.05:2005. 2005. Betoninių ir gelžbetoninių konstrukcijų projektavimas, Lietuvos Respublikos Aplinkos ministerija, 121 p.

Stramandinoli, R. S. B.; Rovere, H. L. L. 2008. An efficient tension-stiffening model for nonlinear analysis of reinforced concrete members, Engineering Structures 30(7): 20692080. 
Suidan, M.; Schnobrich, W. C. 1973. Finite element analysis of reinforced concrete, ASCE Journal of the Structural Division 99(10): 2109-2122.

Szulczynski, T.; Sozen, M. A. 1961. Load-deformation characteristics of reinforced concrete prisms with rectilinear transverse reinforcement. Structural Research Series 224, University of Illinois. 41 p.

Šimkus, R. 1998. Naujas metodas lenkiamų gelžbetoninių elementų kreiviui skaičiuoti, Statybinès konstrukcijos: kūrimas ir stiprinimas. Vilnius, Technika: 32-37.

Teng, S.; Branson, D. E. 1993. Initial and time - depend deformation of progressively cracking nonprestressed and partially prestressed concrete beams, Aci Journal 90(5): $480-488$.

Thorenfeldt, E.; Tomaszewicz, A.; Jensen, J. J. 1987. Mechanical properties of highstrength concrete and application in design. Proceedings, Symposium in Stavanger, Norway: 17-22.

Torres, L.L., Lopez-Almansa, F., Bozzo, L.M., 2004. Tension-stiffening model for cracked flexural concrete members. ASCE Journal of Structural Engineering, 130(8): 1242-1251.

Vecchio, F. J.; Collins M. P. 1982. Response of reinforced concrete to in-plane shear and normal stresses. Publication No. 82-03, Department of Civil Engineering, University of Toronto, $332 \mathrm{p}$.

Vecchio, F. J.; Collins, M. P. 1986. The Modified Compression Field Theory for reinforced concrete elements subjected to shear, ACI Structural Journal 83 (6): 925-933.

Vecchio, F. 2000. Disturbed Sress field model for Reinforced concrete, Journal of Structural Engineering, New York: ASCE, v. 126: 1070-1077.

Vollum, R. L.; Afshar, N.; Izzuddin, B. A. 2008. Modelling short-term tension stiffening in tension members, Magazine of Concrete Research 60(4): 291-300.

Walsh, P. F. 1972. Fracture of plain concrete, The Indian Concrete Journal 46(11): 469470, 476.

Walsh, P. F. 1976. Crack initiation in plain concrete, Magazine of Concrete Research 28(94): 37-41.

Wang, P. T.; Shah, S. P.; Naaman, A. E. 1978. Stress-strain curves of normal and lightweight concrete in compression, ACI Journal Proceedings 75(11): 603-611.

Watstein, D., Seese, N. A. 1945. Effect of type of bar on width of cracks in reinforced concrete subjected to tension, ACI Journal V. 41, No. 2: 293-304.

Watstein, D. 1947. Distribution of bond stress in concrete pull-out speciments, ACI Journal V. 43, No. 5: 1041-1052. 



\section{Autoriaus publikaciju disertacijos tema sąrašas}

\section{Straipsniai recenzuojamuose mokslo žurnaluose}

Kaklauskas, G.; Gribniak, V.; Girdžius, R. 2011. Average Stress - Average Strain Tension Stiffening Relationships Based on Provisions of Design Codes. Journal of Zhejiang Univercity - SCIENCE $A$ Vol.12 No.10: 731-736. ISSN 1673-565X (print), ISSN 18621775 (online). (ISI Web of Science).

Kaklauskas, G.; Girdžius, R.; Bacinskas, D.; Sokolov, A. 2008 Numerical Deformation Analysis of Bridge Concrete Girders. The Baltic Journal of Road and Bridge Engineering, 3(2): 51-56. ISSN 1822-427X (print), ISSN 1822-4288 (online). (ISI Web of Science).

Girdžius, R.; Kaklauskas, G.; Zamblauskaitè, R.; Jakubovskis, R. 2011. Naujasis lenkiamojo gelžbetoninio elemento, veikiamo trumpalaikès apkrovos, kreivių apskaičiavimo metodas, Statybinés konstrukcijos ir technologijos 3(3): 112-122. ISSN 2029-2317 (print), ISSN 2029-2325 (online). (Scopus).

Girdžius, R.; Kaklauskas, G.; Zamblauskaitè, R. 2007. Centriškai tempiamo gelžbetoninio elemento betono ịtempių ir deformacijų priklausomybè pagal EC2, Ūkio technologinis ir ekonominis vystymas 13(2): 109-113. ISSN 2029-4913 (print), ISSN 2029-4921 (online). (Scopus). 


\section{Straipsniai kituose leidiniuose}

Girdžius, R.; Gribniak, V. 2005. Betono traukimosi itaka tempiamuju gelžbetoninių elementų deformacijoms, iš 8-osios Lietuvos jaunuju mokslininku konferencijos „Lietuva be mokslo - Lietuva be ateities" medžiaga. Vilnius: technika, 177-181. ISBN 9986058937.

Gribniak, V.; Girdžius, R. 2005. Baigtinių elementu (BE) dydžio ir formos įtaka tempiamujų $\mathrm{G} / \mathrm{B}$ elementų deformacijų skaičiavimo rezultatams, iš 8-osios Lietuvos jaunuju mokslininku konferencijos „Lietuva be mokslo - Lietuva be ateities “ medžiaga. Vilnius: technika, 181-186. ISBN 9986058937.

Girdžius, R. 2006. Centriškai tempiamojo gelžbetoninio elemento betono itempių ir deformaciju priklausomybè pagal EC2 iš 9-osios Lietuvos jaunuju mokslininku konferencijos „Mokslas - Lietuvos ateitis" medžiaga. Vilnius: technika, 143-148. ISBN 9955280476.

Girdžius, R. 2007. Betono įtempių ir deformaciju priklausomybe lenkiamame gelžbetoniniame elemente, iš 10-osios Lietuvos jaunuju mokslininku konferencijos „, Mokslas Lietuvos ateitis " medžiaga. Vilnius: technika, 154-159. ISBN 9789955281634.

Kaklauskas, G.; Gribniak, V.; Girdžius, R.; Vainiūnas, P.; Bačinskas, D. 2010. Tension - stiffening relationships based on design code provisions, in proceedings of the Third international congress and exhibition (FIB) incorporating the PCI annual convention \& bridge conference. Washington: 1-8. 


\section{Summary in English}

\section{Introduction}

\section{Reasons for Investigation}

In the countries all over the world, strength analysis of reinforced concrete (RC) structures is based on a unified approach, i.e. the limit state method. On the contrary, cracking and stiffness techniques of various design codes are based on different assumptions and approaches. Serviceability predictions by different design code methods problems may vary several times.

Main disadvantage of Eurocode design code method is their limited application regarding the structural shape and loading cases. Alternative to the design code methods are numerical techniques. These techniques can evaluate irregular geometrical shape of the structure, specific loading conditions and nonlinear properties of the materials. However, results of analysis become dependent on constitutive models of concrete and reinforcing steel. Modeling reinforcing steel is simple. A large number of models have been proposed for concrete in compression. However, no significant difference is observed when different relationships are used in numerical procedures for deformational analysis of cracked RC beams. It should be noted that modeling behavior of cracked tensile concrete is a much more complicated issue. Due to bond with reinforcement, the cracked concrete between cracks carries a certain amount of tensile force normal to the cracked plane. The concrete adheres to reinforcement bars and contributes to overall 
stiffness of the structure. The phenomenon, called tension-stiffening, has a significant influence on the results of short-term deformational analysis.

Based on a variety of assumptions, many constitutive models for cracked concrete in tension have been proposed for case of short-term loading. Present research was aiming at deriving a tension-stiffening relationship for numerical analysis of bending RC members, wich allow predicting deformations with accordance to the Eurocode provisions. According to the algorithm proposed by the supervisor of the thesis, the tensionstiffening relationship has been derived from moment-curvature diagrams of reinforced concrete beams, calculated using the Eurocode technique. The obtained tensionstiffening relationship was applied in the numerical analysis using finite element software and Layer section model. The calculation results were compared with experimental data of beams reported in the literature.

\section{Research Object and Methods}

The problem of constitutive modelling of tension-stiffening as well as deformations of reinforced concrete members was examined. The proposed tension-stiffening models are based on the inverse technique using the Eurocode curvature predictions. Reinforced concrete numerical simulation (finite elements and Layer section models, inverse deformation analysis technique) and statistical analysis methods are used in this study.

\section{Main Objective}

Based on the Eurocode technique, to propose tension-stiffening law for reinforced concrete tension and bending members subjected to short-term loading, which can be applied in numerical analysis.

\section{Main Tasks}

1. To perform a literature review on deformation calculation methods and constitutive models of reinforced concrete members.

2. To derive tension-stiffening relationship for reinforced concrete tension and bending members according to the Eurocode technique.

3. To identify the parameters, having influence on the shape of tension-stiffening diagram of cracked concrete.

4. To propose tension-stiffening models for reinforced concrete tension and bending members.

5. To apply the proposed tension-stiffening models in deformation analysis.

6. To collect test data on deformation behaviour of reinforced concrete tension and bending elements published in the literature.

7. For the collected test data set, to perform comparative statistical analysis of deformations and deflections prediction techniques using the proposed tension-stiffening and other models. 


\section{Scientific Novelty and Originality}

Based on the scientific supervisor created algorithm for solving an inverse problem, tension-stiffening models have been proposed corresponding to the Eurocode deformation calculation technique. It was shown that the proposed models can be used in numerical analysis. Different complexity tension-stiffening models have been obtained for reinforced concrete tension and bending members. The proposed tension-stiffening models depend on concrete tensile strength, reinforcement ratio and the modular ratio.

Using test data reported in the literature, a statistical analysis of accuracy of deformation and deflection prediction techniques has been performed.

\section{Practical Value}

The proposed tension-stiffening model can be used both in standard finite element software and in Layer model satisfying deformation predictions requirements of the Eurocode.

\section{Basic Statements to be Defended}

1. The inverse calculation technique can be used for developing tension-stiffening models corresponding to design code requirements.

2. Tension-stiffening models for reinforced concrete bending and tension members are different with the tension-stiffening effect more expressed in the latter members.

3. The proposed tension-stiffening models, both fot tensile and bending members, depend on concrete tensile strength, reinforcement ratio and the reinforcement and concrete modular ratio.

\section{Approval of the Research Results}

9 scientific articles were published on the topic of the dissertation: 4 - in reviewed scientific journals, (2 from them included in ISI WEB of Science international databases); 5 articles in conferences materials ( 1 from them in international conference material):

- The third international Congress and exhibition (FIB) incorporating the PCI annual convention \& bridge conference, Washington, USA, 2010.

- The Tenth Lithuanian Conference of Young Scientists Science - Future of Lithuania, Vilnius, Lithuania, 2007.

- The Ninth Lithuanian Conference of Young Scientists Science - Future of Lithuania, Vilnius, Lithuania, 2006.

- The Eighth Lithuanian Conference of Young Scientists Lithuania without Science - Lithuania without the Future, Vilnius, Lithuania, 2005.

\section{The Scope of the Scientific Work}

The dissertation consists of introduction, four Chapters, general conclusion and a list of references.

The total scope of dissertation - 110 pages, 143 expressions, 54 figures, 2 tables and 155 references. 


\section{Overview of stress-strain calculation methods and models for reinforced concrete members}

This chapter reviews both empirical and numerical methods of deformation analysis of RC members. In the state-of-art summary on various stress-strain relationships for concrete and reinforcement, a special empahasis is made on critical survey of modelling post-cracking behaviour of tensile concrete in smeared crack approach.

Stress-strain diagram of cracked tensile concrete has significant influence on calculation of deformations of RC members. However, in Eurocode only the strees-strain diagram of concrete in compression is presented. This is the main reason why engineers can not perform stress-strain analysis of complicated structures using numerical methods. Based on the above, the following objective has been set: to propose average-strain tension-stiffening laws for tensile and flexular reinforced concrete members subjected to short-term loading, which allow predicting deformations with accordance to the Eurocode.

\section{Tension-stiffening model for reinforced concrete tension members}

In this Chapter derivation of stress-strain tension-stiffening model for tensile RC members is considered. A numerical experiment has been performed based on deformation analysis of tensile RC elements according to the Eurocode. In the parametric analysis, 160 load-strain diagrams were calculated with ranging in reinforcement ratio $(0,2,0,4, \ldots$, and $2,0 \%)$, grade of concrete $(\mathrm{C} 20 / 25, \mathrm{C} 30 / 37, \mathrm{C} 35 / 45$, and $\mathrm{C} 65 / 75)$, modulus of elasticity steel $(170,190$, and $210 \mathrm{GPa})$. Some of the load-strain diagrams are shown in Figure 1a.

For any loading stage equilibrium equation can be given:

$$
N_{s m}+N_{c m}=P,
$$

where $N_{s m}$ and $N_{c m}$ are mean internal forces in reinforcement and concrete, respectively. When the strain is known, stress in reinforcement can be calculated:

$$
N_{s m}=A_{s} E_{s} \varepsilon_{s m},
$$

where $\varepsilon_{s m}$ is average strain in reinforcement; $E_{s}$ is modulus of elasticity of reinforcement; $A_{s}$ is cross-section area of tensile reinforcement.

From the expressions (1) and (2) mean stress in concrete is defined as:

$$
N_{c m}=P-A_{s} E_{s} \varepsilon_{s m} .
$$

Apllying formula (3) mean stress in reinforcement can be found: 


$$
\sigma_{t_{m}}=\frac{P-A_{s} E_{s} \varepsilon_{s m}}{A_{c}} .
$$
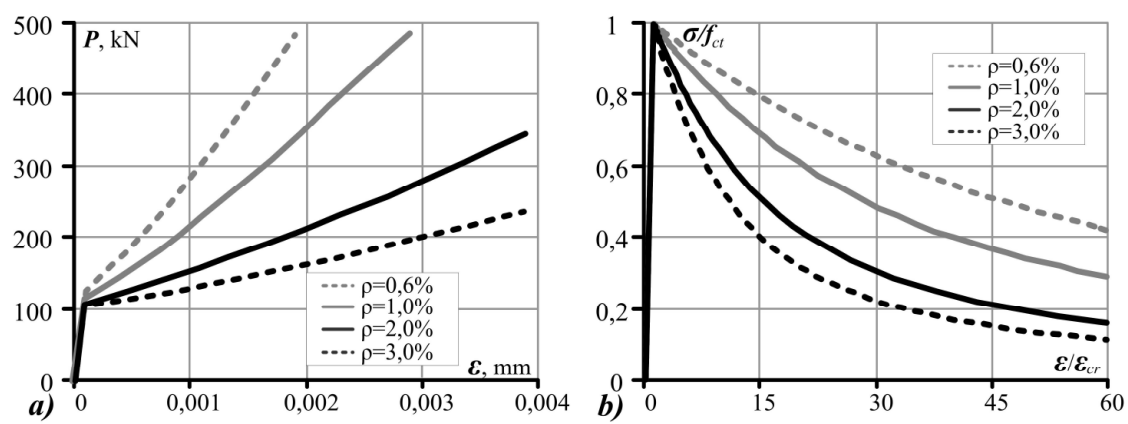

Fig. 1. (a) Load - deformation and (b) numerically derived stress - strain diagrams for varying reinforcement ratio. Grade of concrete $\mathrm{C} 20 / 25$

Tension-stiffening relationships were derived from each load-strain diagram with some examples shown in Figure 1b. The average stress-average strain tension stiffening diagrams consisted of two branches: ascending and descending. These branches represent the elastic and the tension-stiffening behaviour, respectively. Based on a regression analysis, the following tension-stiffening model has been proposed:

$$
\sigma_{t}=\frac{f_{c t}}{1+A\left(\frac{\varepsilon}{\varepsilon_{c r}}-1\right)^{1,15}}, A=0,0022(2 \rho n-1),
$$

where $\mathrm{n}$ is the modulus ratio.

To verify adequacy of the proposed model, for the newly generated data set loadstrain diagrams were calculated by formulae (1) to (4) and the Eurocode. The disagreement between the calculated strains has not exceeded $1 \%$.

\section{Tension-stiffening model for reinforced concrete bending members}

This Chapter is aimed at deriving tension-stiffening relationship for deformation analysis of bending RC members. The analysis was based on direct and inverse techniques proposed by G. Kaklauskas and further modified by V. Gribniak.

The analysis uses formulae of strength of materials extended to application of Layer section model and material diagrams. The following approaches and assumptions have been adopted: 1) smeared crack approach; 2) linear strain distribution within the depth of the section implying perfect bond between concrete and reinforcement; 3) all concrete fibers in the tension zone follow a uniform stress-strain tension-stiffening law. 
The direct analysis is aimed at the prediction of structural response using the specified constitutive model. Let us consider a doubly reinforced concrete section subjected to pure bending. The cross-section is divided into horizontal layers corresponding to either concrete or reinforcement (Fig. 2b).
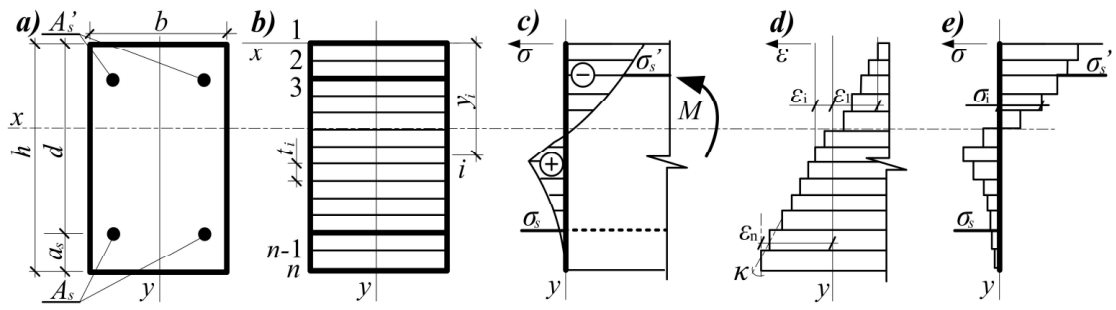

Fig. 2. Layer section model of RC section

Curvature $\kappa$ and strain $\varepsilon_{i}$ at any layer $i$ (see Figure 2d) are calculated by the formulae:

$$
\begin{gathered}
\kappa=M /(I E), \varepsilon_{i}=M\left(y_{i}-y_{R C}\right) /(I E), y_{R C}=S E /(A E), \\
A E=\sum_{i=1}^{n} b_{i} t_{i} E_{i}, S E=\sum_{i=1}^{n} b_{i} t_{i} E_{i} \\
I E=\sum_{i=1}^{n}\left[b_{i} t_{i}^{3} / 12+b_{i} t_{i}\left(y_{i}-y_{R C}\right)^{2} E_{i}, E_{i}=\sigma_{i} / \varepsilon_{i},\right.
\end{gathered}
$$

where $M_{e x t}$ is the external bending moment; $A E, S E$ and $I E$ are the area, the first and the second moments of the area multiplied by the secant modulus; $n$ is the total number of layers; $b_{i}$ and $t_{i}$ are the width and thickness of the $i$-th layer, respectively; $y_{i}$ is the distance of the $i$-th layer from the top edge of the section (fig. 2b). For the given strains and constitutive laws (fig. 2d. and 2c), stresses and corresponding secant modulus are calculated. The analysis is performed iteratively until convergence of the secant modulus at each layer is reached. Figures $2 \mathrm{~d}$ and $2 \mathrm{e}$ illustrate strain and stress distributions within the layer section model.

Differently from the direct analysis, the inverse technique aims at determining parameters of the model based on the response of the structure. The principles of the inverse technique for deriving stress-strain tension stiffening relationship using test data of $\mathrm{RC}$ flexural members have been formulated by the supervisor of the thesis. For given experimental moment-curvature curve, a stress-strain relationship was defined from the equilibrium equations of the axial forces and the bending moments. The layer section model (fig. 2b) was employed for computation of the internal forces. The analysis was performed via load (bending moment) increments. The two equilibrium equations were solved for each loading stage yielding a solution for the coordinate of neutral axis and the concrete stress in the extreme tension fiber. Since the extreme fiber had the largest strain, other tension fibers of concrete had smaller strains falling within the portion of the stress-strain diagram which had already been determined (see the third assumption). The average stress-strain relationship of concrete in tension was progressively derived assuming the portions obtained from the previous increments. 
The inverse technique was applied for deriving tension-stiffening relationships using the moment-curvature diagrams calculated by the Eurocode. The diagrams were calculated for a number of reinforced concrete sections having different amount of tensile reinforcement $\left(\rho=A_{s} / b d=0,2,0,4, \ldots\right.$, and $2,0 \%$ ), grade of concrete $(\mathrm{C} 20 / 25, \mathrm{C} 30 / 37$, C35/45, and C65/75), effective depth $(d / h=0,75-0,975)$, and modulus of elasticity of steel $(170,190$, and $210 \mathrm{GPa})$. The ratio of the area of compressive and tensile reinforcement, was taken to be 0,25 .

For the above model parameters, 450 moment-curvature diagrams were generated. For each of them, tension-stiffening relationship was obtained. Some of the calculated diagrams are shown in Figure 3. A regression analysis performed has shown that the tension-stiffening relationships significantly (in statistical sence) depend on the reinforcement ratio $\rho$ and the reinforcement and concrete modulus ratio $n$. The analysis has resulted in the following expression for modeling tension-stiffening:

$$
\sigma_{t}=\frac{f_{c t}}{1+A\left(\frac{\varepsilon}{\varepsilon_{c r}}-1\right)^{0,5}}, A=0,76+0,165 \rho n .
$$

In Chapter 3, a simple technique has been proposed for curvature analysis of RC members. As shown in Figure 3, moment-curvature diagram consists of two linear parts. In the first part (uncracked state) curvature is calculated using classical formulae of strength of materials:

$$
\kappa_{e l}=\frac{M}{E_{c} I_{e l}} .
$$

In the second part (cracked state), curvature is calculated by linear interpolation between two characteritic points A and B where B is the curvature obtained by the Eurocode at $0,6 \mathrm{Mu}$. This stage is represented by the following formula:

$$
\kappa=\frac{M_{c r}}{E_{c} I_{e l}}+\frac{M-M_{c r}}{E_{c} I_{e l} \gamma},
$$

Here $I_{\mathrm{el}}$ is the moment of inertia of uncracked section; $E_{\mathrm{c}}$ is the modulus of elasticity of concrete.

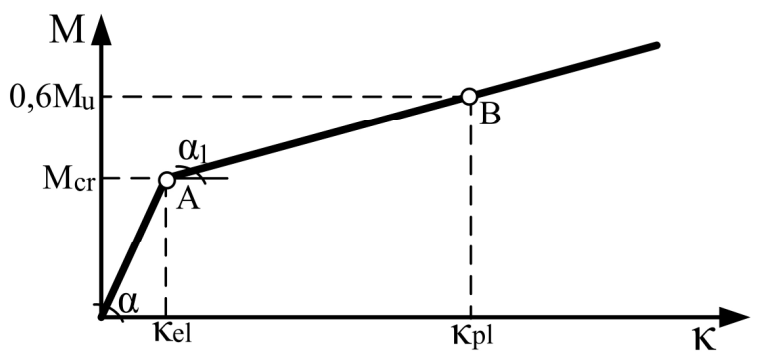

Fig. 3. Moment-curvature diagram for reinforced concrete bending member 
Factor $\gamma$ is calculated from the following expresion:

$$
\gamma=-0,033-0,354 d / h-0,092 \ln \left(\frac{\rho n}{d / h}\right)+0,436 d / h(\rho n)^{0,4} .
$$

A statistical analysis performed has shown an adequate accuracy of the simplified technique proposed. The extreme curvature prediction errors have not exeeded $10 \%$.

\section{Numerical and comparative calculations using proposed materials models}

This Chapter presents statistical analysis on accuracy of short - term deformation predictions using the proposed constitutive laws and other techniques. The first part of the chapter is dedicated to the analysis of tensile members, whereas the second part is dealing with flexural members.

The calculation of deflections for both tensile and flexural members is done introducing ten levels of loading intensity $P^{\prime}=0,1,0,2,0,3,0,4,0,5,0,6,0,7,0,8,0,9$ and 1,0 , where $P^{\prime}$ is estimated according to the formula:

$$
P^{\prime}=\left(P-P_{c r}\right) /\left(P_{u}-P_{c r}\right),
$$

where $P_{c r}$ is cracking force; $P_{u}$ is ultimate force.

Accuracy of the predictions was estimated by means of a relative $\Delta_{i, k}$ calculated at each load level $P^{\prime}$ for each experimental member:

$$
\Delta_{i, k}=\delta_{\text {calc }} / \delta_{\text {obs }}, i=1,2,3, \ldots, 10 .
$$

The analysis of tensile members was based on the following models and methods: CEB-FIP, Hsu, Collins and Mitchell, Fields and Bischoff. The statistical analysis of deformation calculation accuracy of tensile RC members has been performed for the 293 experimental output points. The analysis has shown that deformations of tensile RC members calculated according to the Eurocode technique was significantly less than experimental. For lightly reinforced members $(\rho \leq 1,5 \%)$ at the loading stage close to cracking, the obtained deformations on average reached $40 \%$ of experimental values (when concrete shrinkage was not taken into account). Relative mean error varied in the range of $0,40-0,57$, in every loading level, whereas for the members with high reinforcement ratio relative error was less, i.e. $0,58-0,80$. Good agreement with experimental data was reached after elimination of concrete shrinkage. Relative mean error varied in the following range: for lightly reinforced members $(\rho \leq 1,5 \%) 0,70-0,79$ and for the members with high reinforcement ratio $0,86-0,99$. Relative mean error applying the methods, proposed by other authors, varied in the following range: $0,64-0,70$ (CEBFIP), 0,74-1,12 (Hsu), 0,64-0,85 (Collins and Mitchell), 0,83-0,92 (Fields and Bischoff). The following results were obtained for the members with high reinforcement ratio $(1,5 \%<\rho): 0,77-0,85(C E B-F I P), 0,85-1,08(H s u), 0,76-0,91$ (Collins and Mitchell), 0,85-0,94 (Fields and Bischoff). 
The Chapter also deals with the statistical analysis of deflection calculation accuracy of flexural RC members, applying the following models and methods: Eurocode 2, ACI 318, SP 52-101, CEB-FIP, STR 2.02.02:2005, Collins and Mitchell, Fields and Bischoff. The experimental data of $40 \mathrm{RC}$ beams (400 points of deflection) was used. Accuracy of the predictions varied significantly within different intervals of reinforcement ratio and load intensity. Significant errors in terms of mean deviation were obtained for lightly reinforced beams $(\rho<0,5 \%)$. The relative mean error for different methods varied in the following range: 0,97-1,74 (Eurocode 2), 0,93-2,32 (SP52-101), 0,94-1,90 (STR 2.05.05:2005), 0,64-1,27 (CEB-FIP), 0,81-1,33 (Collins and Mitchell), 0,66-1,90 (Fields and Bischoff), 0,92-1,26 (Hsu), 0,96-1,75 (proposed tensionstiffening model for flexural RC elements, model a), 1,05-1,69 (proposed simplified cuvature calculation method, model $b$ ). Whereas the relative mean error for the beams with average and high reinforcement ratio $(\rho>1,0 \%)$ was: 0,88-1,05 (Eurocode 2), 0,86-1,07 (SP52-101), 0,97-1,03 (STR 2.05.05:2005), 0,83-0,87 (CEB-FIP), 0,86-0,90 (Collins and Mitchell), 0,91-1,03 (Fields and Bischoff), 0,89-0,90 (Hsu), 0,91-1,08 (proposed tension-stiffening model for flexural RC elements, model a), 0,91-0,94 (proposed simplified cuvature calculation method, model $b$ ).

The results of this study have shown that tension stiffening models for tensile and flexural RC elements are different. The predictions where over estimated up to $40 \%$ while employing tensile element model for the analysis of flexural members. The errors increase with the decreasing reinforcement ratio.

\section{General conclusions}

1. Main disadvantage of Eurocode design code method is their limited application regarding the structural shape and loading cases. The numerical methods can be applied for calculating of deformations of such elements, in which nonlinear material models are evaluated. Stress-strain model for cracked tensile concrete (tension-stiffening) has great influence on deformation calculation. Unfortunately, this model do not submitted in Eurocode, but only stress-strain diagram of compressive concrete are given. Therefore designers cannot perform stress-strain state analysis of complicated structures using numerical methods according the Eurocode.

2. Usually tension-stiffening models were derived from tension test and then applied for deflection calculation of reinforced concrete beams. Errors in calculated deflections using these models may be of low accuracy. In this thesis tension-stiffening models were obtained from reinforced concrete flexural and tension members, wich allow predicting deformations with accordance to the Eurocode provisions. The algorithm proposed by the supervisor of the thesis was used for determining an average stress-average strain relationship from moment-curvature diagram.

3. The proposed tension-stiffening models consist of two branches: elastic ascending and descending, which corresponds to cracked concrete behaviour. The shape of descending branch mostly depends on concrete tensile strength, reinforcement steel and concrete modular ratios. 
4. The proposed tension-stiffening laws have been introduced into the layer section model for predicting tensile deformations and curvatures of reinforced concrete elements. The calculation errors both for tension and bending members not exceed $1 \%$.

5. Research result has shown that tension-stiffening models for reinforced concrete tension and bending members are different. About $40 \%$ error has been obtained using tension-stiffening model for bending members, which was derived from tension members. Errors increase with reducing in reinforcement ratio.

6 . The accuracy of statistical analysis on deformation of reinforced concrete tension members has been performed for the 293 experimental output points. The analysis has shown that reinforcement ratio and load intensity have influence on accuracy of the predictions. Relative mean error for lightly reinforced members varied in the following range: $0,64-0,70(C E B-F I P), 0,74-1,12$ (Hsu), 0,64-0,85 (Collins and Mitchell), 0,830,92 (Fields and Bischoff). The following results were obtained for the members with high reinforcement ratio $(\rho>1,5 \%): 0,77-0,85$ (CEB-FIP), 0,85-1,08 (Hsu), 0,76-0,91 (Collins and Mitchell), 0,85-0,94 (Fields and Bischoff).

7. Deformations of reinforced concrete tension members calculated according the Eurocode technique was significantly less than experimental. Obtained deformations were reached at average $39,6 \%$ of experimental values for lightly reinforced members $(\rho \leq 1,5 \%)$, not taking into account concrete shrinkage, at loading stage close to cracking. Relative mean error varied in the following range $0,40-0,57$. Whereas error for the members with high reinforcement ratio was leser: $0,58-0,80$. The obtained results were well-agreed with experimental data, when concrete shrinkage was eliminated. Relative mean error varied in the following range: for lightly reinforced members $(\rho \leq 1,5 \%)$ $0,70-0,79$ and for the members with high reinforcement ratio $0,86-0,99$.

8 . Accuracy of the predictions varied significantly within different intervals of reinforcement ratio and load intensity. Significant errors in terms of mean deviation were obtained for lightly reinforced beams $(\rho<0.5 \%)$. Relative mean error for different methods varied in the following range: 0,97-1,74 (Eurocode 2), 0,93-2,32 (SP52-101), 0,94-1,90 (STR 2.05.05:2005), 0,64-1,27 (CEB-FIP), 0,81-1,33 (Collins and Mitchell), 0,66-1,90 (Fields and Bischoff), 0,92-1,26 (Hsu), 0,96-1,75 (model a), 1,05-1,69 (model $b$ ). Whereas maximal error for the beams with average and high reinforcement ratio ( $\rho>1,0 \%$ ) was: $0,88-1,05$ (Eurocode 2), 0,86-1,07 (SP52-101), 0,97-1,03 (STR 2.05.05:2005), 0,83-0,87 (CEB-FIP), 0,86-0,90 (Collins and Mitchell), 0,91-1,03 (Fields and Bischoff), 0,89-0,90 (Hsu), 0,91-1,08 (model a), 0,91-0,94 (model b). 


\section{Priedai $^{1}$}

A priedas. Eksperimentinių tempiamujuc gelžbetoninių elementų apkrovosdeforamacijų ir tempiamojo sustandejjimo diagramos

B priedas. Skaitinių ir palyginamujų skaičiavimų taikant pasiūlytuosius medžiagų modelius gauti rezultatai

C priedas. Bendraautorių sutikimai teikti publikacijų medžiagą disertacijoje

D priedas. Autoriaus mokslinių publikacijų disertacijos tema kopijos 
Rokas Girdžius

BETONO TEMPIAMOJO SUSTANDĖJIMO

MODELIS ATITINKANTIS EURONORMYQ

NUOSTATAS

Daktaro disertacija

Technologijos mokslai,

statybos inžinerija (02T)

\section{Rokas Girdžius}

TENSION-STIFFENING MODEL FOR

REINFORCED CONCRETE MEMBERS

ACCORDING EUROCODE

Doctoral Dissertation

Technological Sciences,

Civil Engineering (02T) 